KS. MARCIN NABOŻNY* - RZESZÓW

\title{
ARCHIWUM DIECEZJALNE W RZESZOWIE. POWSTANIE, ZASÓB I DZIAŁALNOŚĆ
}

\section{Archiwum historyczne w diecezji}

Diecezja do swojego funkcjonowania potrzebuje istnienia wielu instytucji. Jedną z nich jest historyczne archiwum diecezjalne.

Archiwum to instytucja o charakterze urzędu administracyjnego, urzędu wiary publicznej oraz placówki naukowej, powołana do kształtowania, zabezpieczania, gromadzenia, opracowywania oraz trwałego przechowywania i udostępniania materiałów archiwalnych; uprawniona do wydawania $\mathrm{z}$ nich uwierzytelnionych odpisów, wyciągów, wypisów i kopii, a także do publikowania źródeł i pomocy archiwalnych oraz prowadzenia badań z dziedziny archiwistyki ${ }^{1}$.

Od dawna księgi i dokumenty kościelne przez synody określane były jako skarby Kościoła. Troskę o ten skarb nakazywał już List pasterski z 1601 roku napisany przez bpa krakowskiego Bernarda Maciejowskiego (1548-1608). List ten w 1607 roku został spopularyzowany w całej Polsce 2 .

Terminu archiwum historyczne można użyć na określenie wyspecjalizowanej instytucji powołanej do zabezpieczania, gromadzenia, opracowywania oraz trwałego przechowywania i udostępniania materiałów archiwalnych ${ }^{3}$.

W prawie kościelnym pojęcie archiwum historycznego, jako instytucji gromadzącej materiały archiwalne niepotrzebne do bieżącego funkcjonowania kancelarii kościelnych, pojawiło się dopiero w Kodeksie Prawa Kanonicznego z 1983 $\mathrm{roku}^{4}$.

* Ks. Marcin Nabożny - mgr lic. teologii w zakresie historii Kościoła, doktorant w Instytucie Historii Kościoła KUL.

${ }^{1}$ KPK kan. $491 \S 1$ i 2.

${ }^{2}$ X.Z.Ch., Archiwa kościelne krajowe, w: Encyklopedia Kościelna, red. M. Nowodworski, t. 1, Warszawa 1873, s. 379.

${ }^{3}$ M. Dębowska, Archiwa Kościoła Katolickiego w II Rzeczypospolitej, „Archiwa Biblioteki i Muzea Kościelne" (dalej: ABMK), 92 (2009) s. 39.

${ }^{4}$ Tamże, s. 40. 
Archiwum kościelne powoływane jest do życia na mocy wydania przez właściwą władzę kościelną, w przypadku archiwum diecezjalnego przez ordynariusza diecezji, dokumentu erekcyjnego. Archiwum diecezjalne zostaje powoływane zgodnie z wymogami Kodeksu Prawa Kanonicznego z 1983 roku: „Biskup diecezjalny winien zatroszczyć się także o utworzenie archiwum historycznego, w którym strzeżonoby pilnie dokumenty posiadające walor historyczny, uporządkowane systematycznie"

Korzystanie $\mathrm{z}$ akt i dokumentów winno odbywać się według zasad ustanowionych przez biskupa diecezjalnego, w którego trosce jest pilne przechowywanie akt i dokumentów również archiwów kościołów katedralnych, kolegiackich, parafialnych oraz innych znajdujących się na jego terytorium. Powinien również zobowiązać do sporządzania inwentarzy czy katalogów w dwóch egzemplarzach, które powinny być przechowywane w miejscu ich wytworzenia oraz w archiwum diecezjalnym ${ }^{6}$.

\section{Początki diecezji rzeszowskiej}

Koncepcje utworzenia diecezji rzeszowskiej pojawiły się już za czasów urzędowania bpa przemyskiego św. Józefa Sebastiana Pelczara (1842-1924). Nie wyraził on jednak na to zgody. Do projektów utworzenia tej diecezji nawiązał 19 maja 1920 roku bp Piotr Mańkowski z Kamieńca Podolskiego. Nie spotkało się to jednak z akceptacją wśród biskupów?

Diecezja rzeszowska została powołana do istnienia na mocy bulli Jana Pawła II Totus Tuus Poloniae Populus z dnia 25 marca 1992 roku. Jej pierwszym ordynariuszem został, dotychczasowy biskup pomocniczy archidiecezji krakowskiej - bp Kazimierz Górny ${ }^{8}$. Biskupem pomocniczym został mianowany bp Edward

${ }^{5}$ KPK kan. $491 \S 2$.

${ }^{6}$ KPK kan. $491 \S 1$ i 3.

${ }^{7}$ S. Zych, Z dziejów Kościoła katolickiego na terenie obecnej diecezji rzeszowskiej. Studia i szkice, Kolbuszowa 2010, s. 11-14.

${ }^{8}$ Bp Kazimierz Górny urodził się 24 grudnia 1937 roku w Lubniu k. Myślenic. Święcenia kapłańskie przyjął 29 czerwca 1960 roku z rąk bpa Karola Wojtyły. 27 października 1984 roku został prekonizowany na biskupa tytularnego Pertusy i biskupa pomocniczego w Krakowie. Sakrę otrzymał 6 stycznia 1985 roku w Rzymie z rąk papieża Jana Pawła II. Hasłem jego posługi są słowa Omnia Tibi. 25 marca 1992 roku został biskupem nowo utworzonej diecezji rzeszowskiej. 11 kwietnia 1992 roku odbył uroczysty ingres do katedry rzeszowskiej. Zob. A. Motyka, Redemptori hominis. Dziesięciolecie diecezji rzeszowskiej (1992-2002), Rzeszów 2002, s. 40-42. 
Białogłowski ${ }^{9}$. Patronami diecezji są św. bp Józef Sebastian Pelczar ${ }^{10}$ oraz bł. Karolina Kózkówna, dziewica i męczennica ${ }^{11}$. Jako diecezja sufraganalna weszła w skład metropolii przemyskiej ${ }^{12}$.

Nowa diecezja została utworzona $\mathrm{z}$ diecezji przemyskiej (14 dekanatów) i diecezji tarnowskiej (5 dekanatów). Liczyła około 600 tysięcy mieszkańców, 423 księży diecezjalnych i 68 zakonnych, 224 siostry zakonne. Łącznie w skład diecezji rzeszowskiej wchodziło 19 dekanatów, 201 parafii, 4 rektoraty, ponad 550 księży i około 600 tysięcy mieszkańców ${ }^{13}$.

Diecezja rzeszowska sąsiaduje od wschodu z diecezją przemyską, od północy $\mathrm{z}$ sandomierską i od zachodu z tarnowską. Zajmuje terytorium liczące ponad 4000 $\mathrm{km}^{2}$. Większość mieszkańców to ludność rolnicza, o wielkim przywiązaniu do tradycji i religii ${ }^{14}$.

Obecnie diecezja liczy 24 dekanaty, 241 parafii i niemal 700 kapłanów diecezjalnych i zakonnych ${ }^{15}$.

\section{Archiwum Diecezjalne w Rzeszowie - cel i zadania}

Archiwum Diecezjalne w Rzeszowie to odrębna instytucja diecezjalna o charakterze naukowo-kulturalnym, powołana do istnienia przez bpa rzeszowskiego Kazimierza Górnego w celu gromadzenia, porządkowania i udostępniania materiałów archiwalnych, wytworzonych przez instytucje, urzędy i organizacje kościelne na terenie diecezji rzeszowskiej. Znajduje się ono w siedzibie Kurii Diecezjalnej w Rzeszowie przy ul. Zamkowej 4. Archiwum Diecezjalne w Rzeszowie swymi początkami sięga 25 III 1992, czyli chwili utworzenia diecezji rzeszowskiej. Po-

\footnotetext{
${ }^{9}$ Bp Edward Białogłowski urodził się 8 stycznia 1947 roku w Rzeplinie. 17 czerwca 1972 roku przyjął sakrament kapłaństwa przez posługę bpa przemyskiego Ignacego Tokarczuka. 30 listopada 1987 roku został prekonizowany tytularnym biskupem Pomarii i biskupem pomocniczym w Przemyślu. Sakrę przyjął 6 stycznia 1988 roku. Za hasło swej pasterskiej posługi obrał słowa: In virtute Spiritus Sancti. Od 1990 roku rezydował w Rzeszowie. Po utworzeniu diecezji rzeszowskiej został w niej biskupem pomocniczym i wikariuszem generalnym. Zob. Motyka, Redemptori hominis, s. $42-44$.

${ }^{10}$ Św. Józef Sebastian Pelczar urodził się 17 stycznia 1842 roku w Korczynie. 17 lipca 1864 roku przyjął święcenia kapłańskie. 19 marca 1899 roku bp przemyski Łukasz Ostoja-Solecki udzielił mu sakry biskupiej. Intronizacja bpa Pelczara na biskupa przemyskiego odbyła się 13 stycznia 1901 roku. Bp J. S. Pelczar zmarł 28 marca 1924 roku. 2 czerwca 1991 roku Jan Paweł II dokonał w Rzeszowie uroczystej beatyfikacji, a 18 maja 2003 roku na Placu św. Piotra kanonizacji bp. J. S. Pelczara. Motyka, Redemptori hominis, s. 31-36.

${ }^{11}$ Bł. Karolina Kózka urodziła się 2 sierpnia 1898 roku we wsi Wał-Ruda koło Brzeska. Została zamordowana jako 16-latka przez rosyjskiego żołnierza 18 listopada 1914 roku, broniąc swej czystości. 10 czerwca 1987 roku, podczas wizyty w Tarnowie, papież Jan Paweł II ogłosił ją błogosławioną. Zob. Motyka, Redemptori hominis, s. 36-38.

${ }_{12}$ Tamże, s. 10.

${ }^{13}$ Tamże, s. 14-19.

${ }^{14}$ Tamże, s. 14-18.

${ }^{15}$ Schamatyzm Diecezji Rzeszowskiej, Rzeszów 2010, passim.
} 
czątkowo zajmowało się ono głównie gromadzeniem materiałów, dokumentujących bieżące funkcjonowanie diecezji i wszystkich jej instytucji. Wraz z upływem czasu pojawiła się konieczność jego podziału na archiwum akt bieżących i archiwum historyczne. O ile pierwsze już istniało, to drugie należało zorganizować. W latach 1992-1999 odpowiedzialnym za jego organizowanie był ks. dr Stanisław Nabywaniec ${ }^{16}$. W 1999 roku do realizacji tego zadania oddelegowany został ks. dr Andrzej Motyka, któremu powierzono równocześnie obowiązki dyrektora Archiwum Diecezjalnego. Wkrótce przyjęto statut i regulamin Archiwum Diecezjalnego, opracowano jego strukturę $i$ według niej uporządkowano materiały archiwalne. Od 2003 rozpoczęto udostępnianie badaczom tychże materiałów ${ }^{17}$.

Podstawa aktowa Archiwum Diecezjalnego w Rzeszowie stały się w dużej mierze zbiory archiwów parafialnych wchodzących w skład nowoutworzonej diecezji.

Zgodnie ze szczegółowymi wskazaniami funkcjonowania archiwum zawartymi w statucie, instytucja ta ma także sprawować nadzór nad przechowywaniem dokumentacji archiwalnej w urzędach kurialnych oraz archiwach parafialnych, dekanalnych i archiwach innych instytucji kościelnych na terenie diecezji. Ponadto poszerza własne zasoby nabytkami z terenu diecezji oraz prowadzi własne badania naukowe i publikuje ich wyniki. Do należytego wypełniania swych zadań archiwum posiada magazyn, zawierający właściwe zbiory oraz pracownię wraz z księgozbiorem podręcznym ${ }^{18}$.

\section{Statut Archiwum Diecezjalnego w Rzeszowie}

Projekt Statutu Archiwum Diecezjalnego Diecezji Rzeszowskiej przy Kurii Diecezjalnej w Rzeszowie składał się z 20 punktów. Został on zamieszczony na łamach urzędowego pisma „Zwiastowanie”

Aktualny statut Archiwum Diecezjalnego w Rzeszowie zatwierdzony został przez biskupa rzeszowskiego Kazimierza Górnego na zakończenie pierwszego Synodu Diecezji Rzeszowskiej, 20 listopada 2004 roku w Katedrze Rzeszowskiej i zamieszczony w uchwałach tegoż Synodu ${ }^{20}$.

${ }^{16}$ Ks. dr hab. Stanisław Nabywaniec, prof. UR urodził się 29 marca 1958 roku w Zasławiu. 29 czerwca 1983 roku przyjął święcenia kapłańskie. Od 1986 roku odbywał studia specjalistyczne z historii Kościoła na Katolickim Uniwersytecie Lubelskim. Doktorat uzyskał 13 XII 1990 roku. W 1993 roku został zaangażowany jako asystent, a następnie adiunkt, w Instytucie Historii Kościoła KUL, w Katedrze Historii Kościoła w Czasach Nowożytnych. Habilitował się 16 czerwca 1999 roku. Od 2000 roku pracuje na stanowisku profesora w WSP w Rzeszowie (obecnie Uniwersytet Rzeszowski). Zob. http://www.univ.rzeszow.pl/wsh/historia/index.php?id=zyc_ks_prof (8 XI 2010).

${ }^{17}$ A. Motyka, Archiwum Diecezjalne, w: Encyklopedia Rzeszowa, red. J. Draus, G. Zamoyski, Rzeszów 2011, s. 27.

${ }^{18}$ Pierwszy Synod Diecezji Rzeszowskiej, Rzeszów 2004, s. 400-401.

${ }^{19} \mathrm{~S}$. Nabywaniec, Projekt statutu historycznego archiwum diecezjalnego Diecezji Rzeszowskiej przy Kurii Diecezjalnej w Rzeszowie, „Zwiastowanie”, 8 (1999) nr 1, s. 155-158.

${ }^{20}$ Pierwszy Synod Diecezji Rzeszowskiej, Rzeszów 2004, s. 400-402. 
Statut składa się z czterech rozdziałów (I. Postanowienia ogólne; II. Cel i zadania; III. Zasób archiwalny; IV. Organizacja Archiwum), na które składa się 15 paragrafów.

Zgodnie z niniejszym statutem Archiwum Diecezjalne w Rzeszowie stanowi własność diecezji, funkcjonuje w ramach jej struktur oraz podlega biskupowi rzeszowskiemu, jako władzy nadrzędnej $(\S 1)$. Materialne funkcjonowanie archiwum diecezjalnego zabezpiecza Kuria Diecezjalna w Rzeszowie $(\S 5)^{21}$.

\section{Regulamin Archiwum Diecezjalnego}

Regulamin Archiwum Diecezjalnego w Rzeszowie zamieszczony w uchwałach pierwszego Synodu Diecezjalnego w Rzeszowie, podpisany został przez biskupa rzeszowskiego 20 listopada 2004 roku. Składa się z 12 paragrafów, według których materiały archiwalne przechowywane w Archiwum Diecezjalnym w Rzeszowie, udostępniane są władzy diecezjalnej i jej organom w zakresie ich urzędowania. Mogą być także udostępniane osobom lub instytucjom dla celów naukowo-poznawczych $(\S 1)^{22}$.

Zgodnie z regulaminem nie udostępnia się akt rzeczowych przed upływem 50 lat, a personalnych przed upływem 70 lat od ich wytworzenia. Ten okres, zgodnie $\mathrm{z}$ decyzją biskupa rzeszowskiego, w przypadku niektórych kategorii akt może być zmieniony poprzez jego wydłużenie bądź skrócenie $(\S 2)^{23}$.

Aby skorzystać z zasobów archiwum, zgodnie z postanowieniem regulaminu, jest konieczna pisemna prośba do dyrektora (§ 3). W wypadku, gdy kwerenda dotyczy materiałów zastrzeżonych wymagana jest pisemna zgoda biskupa diecezjalnego (§ 5). Należy w niej uwzględnić wykaz materiałów archiwalnych, z których badacz zamierza skorzystać, temat pracy i jej charakter, zobowiązanie do przestrzegania regulaminu archiwum oraz zobowiązanie o dostarczeniu jednego egzemplarza zredagowanej pracy $(\S 3)^{24}$.

Jeżeli badacz nie jest samodzielnym pracownikiem naukowym (przynajmniej $\mathrm{z}$ tytułem doktora) wówczas do prośby o zezwolenie na korzystanie $\mathrm{z}$ akt winien dołączyć dokument polecający, wydany przez promotora pracy naukowej lub instytucję zlecającą przeprowadzenie badań $(\S 4)^{25}$.

$\mathrm{Z}$ materiałów archiwum można korzystać wyłącznie w pracowni mieszczącej się przy nim (§ 6). Dopuszczeni do kwerendy nie mogą zmieniać ustalonego porządku akt i dokonywać w nich żadnych uszkodzeń (§ 7). Jakiekolwiek kopiowanie dokumentów (skanowanie, fotografowanie) można dokonywać po uzyskaniu zgody dyrektora archiwum $(\S 8)^{26}$.

\footnotetext{
${ }^{21}$ Tamże, s. 400.

${ }^{22}$ Tamże, s. 428-429.

23 Tamże.

${ }^{24}$ Tamże.

25 Tamże.

${ }^{26}$ Tamże, s. 428-429.
} 
Po zakończeniu korzystania z udostępnionych materiałów badacz osobiście jest zobowiązany do ich zwrotu pracownikowi archiwum (§ 9). Publikowanie części zespołów lub pojedynczych dokumentów, rysunków, pieczęci, fotografii, itp., stanowiących własność archiwum, wymaga pisemnej zgody dyrektora (§ 10). W przypadku stwierdzenia uchybień przeciwko przepisom regulaminu, przeprowadzającemu kwerendę może zostać cofnięte pozwolenie na korzystanie $\mathrm{z}$ archiwaliów $(\S 11)^{27}$.

Kwerenda naukowa jest wolna od opłat. Odpłatne są jedynie poszukiwania do celów genealogicznych. Wysokość opłat wnoszonych na konto kurii diecezjalnej ustala ekonom diecezji $(\S 12)^{28}$.

\section{Organizacja Archiwum}

Opiekę nad archiwum diecezjalnym z nominacji biskupa spełnia archiwista. Dla funkcjonowania instytucji historycznego archiwum diecezjalnego nie wystarcza doraźna opieka kanclerza i notariusza, którym podlegają nowe akta znajdujące się w kancelarii kurii. Archiwistą, kierującym archiwum historycznym, powinien być specjalista $\mathrm{z}$ dziedziny archiwistyki i archiwoznawstwa lub historyk. W diecezji należy zadbać o przygotowanie fachowego archiwisty, przez skierowanie na studia archiwistyczne lub kursy podyplomowe dla archiwistów ${ }^{29}$.

Zgodnie ze statutem archiwum bezpośredni zarząd nad instytucją archiwum diecezjalnego sprawuje dyrektor mianowany przez biskupa diecezjalnego (§ 12). Dyrektorowi podlegają zatrudnieni w archiwum pracownicy $(\S 14)$. Dyrektor reprezentuje archiwum na zewnątrz, współpracuje z instytucjami kościelnymi na terenie diecezji, odpowiada za należyty stan zbiór, kieruje bieżącymi pracami archiwum, jak również pracownią naukową i zarządza podręcznym księgozbiorem, prowadzi kancelarię własną archiwum oraz troszczy się o powiększanie zbiorów archiwalnych poprzez pozyskiwanie, a także zakup archiwaliów, czasopism i specjalistycznych książek $(\S 13)^{30}$.

${ }^{27}$ Tamże, s. 429.

${ }^{28}$ Tamże.

29 S. Nabywaniec, Organizacja historycznego Archiwum diecezjalnego, „Zwiastowanie”, 8 (1999) nr 1, s. 151-158.

${ }^{30}$ Pierwszy Synod Diecezji Rzeszowskiej, s. 402. 
Pierwszym dyrektorem Archiwum Diecezjalnego w Rzeszowie w 1999 roku został mianowany ks. dr Andrzej Motyka ${ }^{31}$. Do prac w archiwum, na mocy decyzji bpa Edwarda Białogłowskiego, włączył się również ks. Sławomir Zych ${ }^{32}$.

Archiwum używa podłużnej pieczęcie z godłem i napisem w otoku: Archiwum Diecezjalne w Rzeszowie. Ponadto posługuje się pieczęcią podłużną, zawierającą jej nazwę i adres $(\S 15)^{33}$.

Archiwum Diecezjalne w Rzeszowie

ul. Zamkowa 4

35-032 Rzeszów

tel. 0-17 8524419

e-mail: archiwum@diecezja.rzeszow.pl

Archiwum czynne w poniedziałki w godz. 9:00-13:00 i od 14:00-16:00. Udostępnianie zbiorów po wcześniejszej konsultacji telefonicznej ${ }^{34}$.

\section{Zasób zbiorów Archiwum Diecezji Rzeszowskiej (struktura zbiorów) ${ }^{35}$}

Zgodnie ze statutem Archiwum Diecezjalnego w Rzeszowie (§ 8-11) zbiory archiwum diecezjalnego składają się z:

a. archiwaliów wytworzonych przez instytucje i urzędy kościelne na terenie diecezji rzeszowskiej;

${ }^{31}$ Ks. dr Andrzej Motyka urodził się 11 lipca 1963 roku w Przeworsku. Święcenia kapłańskie przyjął 24 czerwca 1988 roku przez posługę bpa Ignacego Tokarczuka. Tytuł magistra uzyskał na podstawie pracy pt. Ks. Józef Panaś kapelan Legionów i Wojska Polskiego (1887-1927), obronionej na KUL-u w 1988 roku. W latach 1994-1999 odbywał specjalistyczne studia z historii Kościoła w Instytucie Historii Kościoła KUL, zwieńczone doktoratem w 1999 roku na podstawie dysertacji Życie religijne w Rzeszowie w okresie międzywojennym (1918-1939). Od 1999 roku ks. A. Motykę powołano do organizowania i zarządzania Archiwum Diecezjalnym. Zbiory Prywatne Autora, Ankieta $\mathrm{z}$ dn. 03 marca 2010 roku.

${ }^{32}$ Ks. dr Sławomir Zych, urodził się 10 maja 1973 roku w Rzeszowie. W 1998 roku ukończył studia w Wyższym Seminarium Duchownym w Rzeszowie i uzyskał magisterium na Wydziale Teologii KUL. W tym samym roku przyjął święcenia kapłańskie z rąk bpa rzeszowskiego Kazimierza Górnego. W 2000 roku rozpoczął studia specjalistyczne w Instytucie Historii Kościoła KUL. W 2009 roku obronił rozprawę doktorską pt. Funkcjonowanie Diecezji Przemyskiej obrządku łacińskiego w warunkach okupacji niemieckiej i sowieckiej. Od 2006 roku pracownik Instytutu Badań nad Polonią i Duszpasterstwem Polonijnym Katolickiego Uniwersytetu Lubelskiego Jana Pawła II. W pracach w Archiwum Diecezjalnym w Rzeszowie zaangażowany był w dniach od 14 do 31 lipca 2003 roku, od 14 lipca do 31 lipca 2004 roku oraz od 1 do 31 lipca 2005 roku. Zbiory Prywatne Autora, Pismo bpa Edwarda Białogłowskiego do ks. Sławomira Zycha z dnia 04 czerwca 2003 roku (L.dz. 647/03), 11 czerwca 2004 roku (L.dz. 710/27/04), 15 czerwca 2005 roku (L.dz. 803/24/05).

${ }^{33}$ Pierwszy Synod Diecezji Rzeszowskiej, s. 402.

${ }^{34}$ Naczelna Dyrekcja Archiwów Państwowych (dalej: NDAP), Archiwa w Polsce. Informator adresowy, Warszawa 2006, s. 89.

${ }^{35}$ Opracowane na podstawie: A. Motyka, Archiwum Diecezjalne w Rzeszowie (struktura zbiorów), Rzeszów 2007 [mps w Archiwum Diecezjalnym w Rzeszowie]. 
b. archiwaliów dotyczących obecnego terenu diecezji rzeszowskiej (głównie akta parafialne), wytworzonych przez kurie diecezjalne w Przemyślu i Tarnowie;

c. zbiorów archiwów dekanalnych i parafialnych;

d. archiwaliów instytutów życia konsekrowanego i stowarzyszeń życia apostolskiego oraz klasztorów i domów zakonnych z terenu diecezji;

e. archiwaliów organizacji i stowarzyszeń katolickich, ruchów katolickich i grup duszpasterskich;

f. zbiorów kartograficznych, fotograficznych i filmowych oraz zapisów na nowoczesnych nośnikach pamięci, związanych z dziejami diecezji rzeszowskiej;

g. ukazujących się na terenie diecezji czasopism katolickich, plakatów i ulotek o tematyce religijnej oraz opracowań niepublikowanych, dotyczących diecezji rzeszowskiej.

Archiwum powiększa swoje zbiory poprzez przejmowanie akt nowszych z archiwum bieżącego kurii diecezjalnej i jej agend, sądu biskupiego, $z$ archiwów kapitulnych, dekanalnych i parafialnych, $\mathrm{z}$ archiwów organizacji i stowarzyszeń katolickich (§ 9).

W związku z przekazywaniem archiwaliów do archiwum historycznego zostały ustalone zasady:

a) agendy kurii diecezjalnej oraz organizacje i stowarzyszenia katolickie przekazują swe akta po upływie 10 lat od ich zamknięcia;

b) instytucje, organizacje i stowarzyszenia kościelne przekazują swe archiwalia w przypadku zaprzestania swej działalności;

c) sąd diecezjalny przekazuje akta, które zostały zamknięte przed 30 laty;

d) archiwa parafialne przekazują wierzytelne odpisy ksiąg metrykalnych za każdy zakończony rok, w terminie do 15 lutego kolejnego roku;

e) archiwa dekanalne i parafialne przekazują wszystkie akta po upływie 100 lat od ich wytworzenia; $10)$.

f) przejmowanie archiwaliów należy do uprawnień dyrektora archiwum (§

Ponadto archiwum może przejmować na własność bądź w formie depozytu archiwa i zbiory kościelnych i niekościelnych osób prawnych oraz osób prywatnych $(\S 11)$.

Obecnie na zasób Archiwum Diecezjalnego w Rzeszowie składają się następujące zespoły:

Zespół A: Akta Stolicy Apostolskiej

Zespół B: Materiały dotyczące papieży

\section{B/I - Papież Jan Paweł II}

sygn. 1 - Jan Paweł II w Rzeszowie 2 VI 1991 roku

sygn. 2 - Nie odejdziesz z naszych serc. W hołdzie Janowi Pawłowi II uczniowie gimnazjum, Boguchwała 2005.

sygn. 3 - Przyszliśmy do Ciebie... Zbiór poezji uczniowskiej, Iwierzyce 2005, mps 
sygn. 4 - „Jan Paweł II - Orędownik Prawdy”. Dzień Papieski w Szkole Podstawowej nr 16 - Wiersze, Rzeszów 2003, mps

sygn. 5 - Jan Paweł II w oczach dzieci, rkps

sygn. 6 - Prasa o śmierci Jana Pawła II (wybrane tytuły)

sygn. 7 - Dni Papieskie

B/II - Papież Benedykt XVI

sygn. 1 - Benedykt XVI w Częstochowie, 26 V 2006

sygn. 2 - XX Światowy Dzień Młodzieży

\section{Zespól C: Akta Kościoła w Polsce}

Zespół 1: Akta Kurii Diecezjalnej

sygn. 1 - Kancelaria Ogólna

sygn. 2 - Wydział Administracyjny

sygn. 2a - Finanse - Wpłaty z parafii

sygn. 3 - Wydział Duszpasterski

sygn. 4 - Wydział Katechetyczny

sygn. 4a - Teczki personalne katechetów świeckich (w układzie alfabetycznym)

sygn. 5 - Wydział Rodzinny

sygn. 6 - Referat Misyjny

sygn. 7 - Sąd Biskupi

sygn. 8 - Formacja Stała Kapłanów

sygn. 9 - Referat Spraw Zakonnych

sygn. 10 - Archiwum Diecezjalne

sygn. 11 - Sprawozdania pięcioletnie dla Stolicy Apostolskiej (Quinquennalia)

sygn. 11/a - Formularze

sygn. 11/1997 - Ad Limina 1997

sygn. 11/2003 - Ad Limina 2003 - Sprawozdania

sygn. 11/2005 - Ad Limina 2005 - Pamiątki i dokumenty przekazane przez Biskupa Rzeszowskiego

sygn. 11/1997-2003 - La relazione quinquennale 1997-2003

Zespół 2: Akta Biskupów

sygn. 1 - Akta bp. Kazimierza Górnego

sygn. $1 / \mathrm{a}-$ Personalia

sygn. $1 / \mathrm{b}-$ Publikacje

sygn. $1 / \mathrm{c}-$ Korespondencja (pisma wysyłane)

sygn. $1 / \mathrm{d}-$ Korespondencja (pisma otrzymywane)

sygn. 1/e - Materiały różne (czynności pontyfikalne, zaproszenia, itp.)

sygn. 2 - Akta bp. Edwarda Białogłowskiego

sygn. $2 / a-$ Personalia 
sygn. $2 / \mathrm{b}$ - Publikacje

sygn. $2 / \mathrm{c}$ - Korespondencja (pisma wysyłane)

sygn. 2/d - Korespondencja (pisma otrzymywane)

Zespół 3: Akta Rad i Komisji Diecezjalnych

sygn. 1 - Akta Kolegium Konsultorów

sygn. 2 - Akta Rady Kapłańskiej

sygn. 3 - Akta Rady Duszpasterskiej Diecezji

sygn. 4 - Akta Rady ds. Ekonomicznych

sygn. 5 - Akta Diecezjalnej Rady ds. Formacji Stałej Kapłanów Diecezji Rzeszowskiej

sygn. 6 - Akta Kapituł Kanonickich

sygn. 7 -Akta Kongregacji Katechetycznych, Rejonowych i Dekanalnych

sygn. 8 -Akta Komisji ds. Architektury i Sztuki Sakralnej

Zespół 4: Akta Dekanalne

sygn. 1 - Akta Kongregacji Dziekańskich

sygn. 2 - Akta Dekanatów

sygn. 2B-1 - Akta Dekanatu Bieckiego

sygn. 2B-2 - Akta Dekanatu Boguchwalskiego

sygn. 2B-3 - Akta Dekanatu Brzosteckiego

sygn. 2C-1 - Akta Dekanatu Czudeckiego

sygn. 2D-1 - Akta Dekanatu Dębowieckiego

sygn. 2F-1 - Akta Dekanatu Frysztackiego

sygn. 2G-1 - Akta Dekanatu Głogowskiego

sygn. 2G-2 - Akta Dekanatu Gorlickiego

sygn. 2J-1 - Akta Dekanatu Jasielskiego Wschodniego

sygn. 2J-2 - Akta Dekanatu Jasielskiego Zachodniego

sygn. 2K-1 - Akta Dekanatu Kolbuszowskiego

sygn. 2N-1 - Akta Dekanatu Nowożmigrodzkiego

sygn. 2R-1 - Akta Dekanatu Ropczyckiego

sygn. 2R-2 - Akta Dekanatu Rzeszowskiego Farnego

sygn. 2R-3 - Akta Dekanatu Rzeszowskiego Katedralnego

sygn. 2R-4 - Akta Dekanatu Rzeszowskiego Południowego

sygn. 2R-5 - Akta Dekanatu Rzeszowskiego Północnego

sygn. 2R-6 - Akta Dekanatu Rzeszowskiego Wschodniego

sygn. 2R-7 - Akta Dekanatu Rzeszowskiego Zachodniego

sygn. 2S-1 - Akta Dekanatu Sędziszowskiego

sygn. 2S-2 - Akta Dekanatu Sokołowskiego

sygn. 2S-3 - Akta Dekanatu Strzyżowskiego

sygn. 2T-1 - Akta Dekanatu Tyczyńskiego

sygn. 2W-1 - Akta Dekanatu Wielopolskiego

sygn. 3 -Akta Dekanatów z okresu przed powstaniem diecezji 
sygn. 3R - Akta Dekanatu Rzeszowskiego

Zespół 5: Akta Parafialne

sygn. I - Dane statystyczne (sprawozdania z parafii) - lata 1991-1995

sygn. II - Dane statystyczne (sprawozdania z parafii) - lata 1996-2000

sygn. III - Dane statystyczne (sprawozdania z parafii) - lata 2001-

sygn. 1 - Akta Parafii pw. Dobrego Pasterza w Babicy

sygn. 2 - Akta Parafii pw. Nawiedzenia NMP w Baryczce

sygn. 3 - Akta Parafii pw. Imienia Maryi w Bączalu Dolnym

sygn. 4 - Akta Parafii pw. św. Jacka w Będziemyślu

sygn. 5 - Akta Parafii pw. Miłosierdzia Bożego w Białej

sygn. 6 - Akta Parafii pw. Bożego Ciała w Bieczu

sygn. 7 - Akta Parafii pw. św. Anny w Bieczu

sygn. 8 - Akta Parafii pw. Świętej Trójcy w Bieździedzy

sygn. 9 - Akta Parafii pw. św. Michała Archanioła w Binarowej

sygn. 10 - Akta Parafii pw. Podwyższenia Krzyża Świętego w Bliziance

sygn. 11 - Akta Parafii pw. Matki Bożej Nieustającej Pomocy w Błażkowej

sygn. 12 - Akta Parafii pw. Matki Bożej Królowej Polski w Błędowej Tyczyńskiej

sygn. 13 - Akta Parafii pw. św. Wojciecha w Błędowej Zgłobieńskiej

sygn. 14 - Akta Parafii pw. św. Stanisława BM w Boguchwale

sygn. 15 - Akta Parafii pw. Matki Bożej Częstochowskiej w Borku Wielkim

sygn. 16 - Akta Parafii pw. św. Jana Chrzciciela w Bratkowicach

sygn. 17 - Akta Parafii pw. św. Mikołaja w Brzezinach

sygn. 18 - Akta Parafii pw. Znalezienia Krzyża Świętego w Brzostku

sygn. 19 - Akta Parafii pw. św. Marii Magdaleny w Brzyskach

sygn. 20 - Akta Parafii pw. Niepokalanego Serca NMP w Budach Głogowskich

sygn. 21 - Akta Parafii pw. Matki Bożej Śnieżnej w Budziwoju

sygn. 22 - Akta Parafii pw. św. Franciszka z Asyżu w Bystrzycy

sygn. 23 - Akta Parafii pw. św. Maksymiliana Kolbego w Bziance

sygn. 24 - Akta Parafii pw. Matki Bożej Łaskawej w Chmielniku Rzeszowskim

sygn. 25 - Akta Parafii pw. św. Michała Archanioła w Cieklinie

sygn. 26 - Akta Parafii pw. Przemienienia Pańskiego w Cmolasie

sygn. 27 - Akta Parafii pw. św. Stanisława BM w Czarnej Sędziszowskiej

sygn. 28 - Akta Parafii pw. św. Maksymiliana Kolbego w Czeluśnicy

sygn. 29 - Akta Parafii pw. Świętej Trójcy w Czudcu

sygn. 30 - Akta Parafii pw. Matki Bożej Królowej Polski w Dąbrowie

sygn. 31 - Akta Parafii pw. św. Judy Tadeusza w Dąbrówce-Gamrat

sygn. 32 - Akta Parafii pw. Matki Bożej Niepokalanej w Desznicy

sygn. 33 - Akta Parafii pw. św. Bartłomieja Ap. w Dębowcu

sygn. 34 - Akta Parafii pw. św. Stanisława BM w Dobrzechowie

sygn. 35 - Akta Parafii pw. Miłosierdzia Bożego w Domatkowie

sygn. 36 - Akta Parafii pw. Dobrego Pasterza w Faliszówce

sygn. 37 - Akta Parafii pw. Najświętszego Serca Pana Jezusa w Foluszu 
sygn. 38 - Akta Parafii pw. Narodzenia NMP we Frysztaku sygn. 39 - Akta Parafii pw. św. Maksymiliana Kolbego w Gliniku sygn. 40 - Akta Parafii pw. św. Józefa Robotnika w Gliniku Polskim sygn. 41 - Akta Parafii pw. Matki Bożej Częstochowskiej w Gliniku Zaborowskim sygn. 42 - Akta Parafii pw. Narodzenia św. Jana Chrzciciela w Gładyszowie sygn. 43 - Akta Parafii pw. Świętej Trójcy w Głogowie Małopolskim sygn. 44 - Akta Parafii pw. św. Maksymiliana Kolbego w Głojscach sygn. 45 - Akta Parafii pw. św. Krzysztofa w Godowej sygn. 46 - Akta Parafii pw. św. Katarzyny w Gogołowie sygn. 47 - Akta Parafii pw. Matki Bożej Nieustającej Pomocy w Gorlicach - Gliniku Mariampolskim sygn. 48 - Akta Parafii pw. Narodzenia NMP w Gorlicach sygn. 49 - Akta Parafii pw. św. Andrzeja Boboli w Gorlicach sygn. 50 - Akta Parafii pw. św. Jadwigi Królowej w Gorlicach sygn. 51 - Akta Parafii pw. św. Jakuba Starszego Ap. w Górze Ropczyckiej sygn. 52 - Akta Parafii pw. Ofiarowania NMP w Górnie sygn. 53 - Akta Parafii pw. Niepokalanego Serca NMP i św. Stanisława Kostki w Grodzisku Strzyżowskim sygn. 54 - Akta Parafii pw. św. Antoniego Padewskiego w Gwoźnicy Górnej sygn. 55 - Akta Parafii pw. św. Doroty w Harklowej sygn. 56 - Akta Parafii pw. Matki Bożej Niepokalanej w Hermanowej sygn. 57 - Akta Parafii pw. Matki Bożej Królowej w Jabłonicy sygn. 58 - Akta Parafii pw. Zwiastowania Pańskiego w Januszkowicach sygn. 59 - Akta Parafii pw. św. Stanisława Kostki w Jasionce sygn. 60 - Akta Parafii pw. Chrystusa Króla w Jaśle (Brzyszczki) sygn. 61 - Akta Parafii pw. Dobrego Pasterza w Jaśle (Sobniów) sygn. 62 - Akta Parafii pw. Matki Bożej Częstochowskiej w Jaśle sygn. 63 - Akta Parafii pw. Matki Bożej Królowej Świata w Jaśle (Niegłowice) sygn. 64 - Akta Parafii pw. Miłosierdzia Bożego w Jaśle sygn. 65 - Akta Parafii pw. Najświętszego Serca Pana Jezusa i Niepokalanego Serca NMP w Jaśle (Górka) sygn. 66 - Akta Parafii pw. św. Antoniego w Jaśle (Franciszkanie) sygn. 67 - Akta Parafii pw. św. Stanisława BM w Jaśle sygn. 68 - Akta Parafii pw. Wniebowzięcia NMP w Jaśle (Fara) sygn. 69 - Akta Parafii pw. Podwyższenia Krzyża Świętego w Jaszczwi sygn. 70 - Akta Rektoratu pw. Matki Bożej Wspomożenia Wiernych w Jaworniku

Niebyleckim sygn. 71 - Akta Parafii pw. Najświętszego Serca Jezusowego w Kamieniu sygn. 72 - Akta Parafii pw. Podwyższenia Krzyża Świętego w Kamionce sygn. 73 - Akta Parafii pw. Podwyższenia Krzyża Świętego w Kawęczynie sygn. 74 - Akta Parafii pw. Matki Bożej Królowej Polski w Kątach sygn. 75 - Akta Parafii pw. Wniebowstąpienia Pańskiego w Kielnarowej sygn. 76 - Akta Parafii pw. św. Maksymiliana Kolbego w Klęczanach sygn. 77 - Akta Parafii pw. św. Jana Chrzciciela w Kobylance 
sygn. 78 - Akta Parafii pw. Matki Bożej Wspomożenia Wiernych w Kolbuszowej

sygn. 79 - Akta Parafii pw. św. Brata Alberta w Kolbuszowej

sygn. 80 - Akta Parafii pw. Wszystkich Świętych w Kolbuszowej (Fara)

sygn. 81 - Akta Parafii pw. św. Anny w Kołaczycach

sygn. 82 - Akta Parafii pw. Najświętszego Serca Jezusowego w Kosowach

sygn. 83 - Akta Parafii pw. Niepokalanego Serca NMP w Krasnej

sygn. 84 - Akta Parafii pw. Wniebowzięcia NMP w Krasnem

sygn. 85 - Akta Parafii pw. św. Maksymiliana Kolbego w Krempnej

sygn. 86 - Akta Parafii pw. Matki Bożej Królowej Polski w Krygu

sygn. 87 - Akta Parafii pw. św. Maksymiliana Kolbego w Krzywej Wsi - Podlesiu

sygn. 88 - Akta Parafii pw. św. Jana Chrzciciela w Kupnie

sygn. 89 - Akta Parafii pw. Narodzenia NMP w Libuszy

sygn. 90 - Akta Parafii pw. Wniebowzięcia NMP w Lipinkach

sygn. 91 - Akta Parafii pw. św. Urszuli w Lubeni

sygn. 92 - Akta Parafii pw. św. Mikołaja w Lubli

sygn. 93 - Akta Parafii pw. Wniebowzięcia NMP w Lutczy

sygn. 94 - Akta Parafii pw. Matki Bożej Częstochowskiej i św. Józefa w Lutoryżu

sygn. 95 - Akta Parafii pw. św. Andrzeja Ap. i Narodzenia NMP w Łączkach

Jagiellońskich

sygn. 96 - Akta Parafii pw. św. Bartłomieja Ap. w Łączkach Kucharskich

sygn. 97 - Akta Parafii pw. św. Onufrego w Łące

sygn. 98 - Akta Parafii pw. Podwyższenia Krzyża Świętego w Łękach Strzyżow-

skich

sygn. 99 - Akta Parafii pw. św. Mikołaja w Łężynach

sygn. 100 - Akta Parafii pw. św. Ignacego Antiocheńskiego i św. Maksymiliana

Kolbego w Łowisku

sygn. 101 - Akta Parafii pw. Miłosierdzia Bożego w Łukawcu

sygn. 102 - Akta Parafii pw. św. Piotra i św. Pawła w Łukawcu Dolnym

sygn. 103 - Akta Parafii pw. św. Wawrzyńca w Malawie

sygn. 104 - Akta Parafii pw. św. Michała Archanioła w Małej

sygn. 105 - Akta Parafii pw. Wniebowzięcia NMP w Małastowie

sygn. 106 - Akta Parafii pw. Matki Bożej Królowej Polski w Matysówce

sygn. 107 - Akta Parafii pw. Matki Bożej Nieustającej Pomocy w Mazurach

sygn. 108 - Akta Parafii pw. Nawiedzenia NMP w Medyni Głogowskiej

sygn. 109 - Akta Parafii pw. św. Kosmy i św. Damiana w Męcinie Wielkiej

sygn. 110 - Akta Parafii pw. św. Huberta w Miłocinie

sygn. 111 - Akta Parafii pw. Podwyższenia Krzyża Świętego i NMP Matki Kościoła w Mogielnicy

sygn. 112 - Akta Parafii pw. św. Łukasza Ewangelisty w Mrowli

sygn. 113 - Akta Parafii pw. św. Andrzeja Boboli w Nawsiu

sygn. 114 - Akta Parafii pw. Znalezienia Krzyża Świętego w Niebylcu

sygn. 115 - Akta Parafii pw. Matki Bożej Nieustającej Pomocy w Niechobrzu

sygn. 116 - Akta Parafii pw. Chrystusa Króla w Niedźwiadzie

sygn. 117 - Akta Parafii pw. św. Bartłomieja Ap. w Nienadówce 
sygn. 118 -Akta Parafii pw. Wniebowzięcia NMP w Nienaszowie sygn. 119 - Akta Parafii pw. św. Anny w Niewodnej sygn. 120 - Akta Parafii pw. św. Mikołaja w Niwiskach sygn. 121 - Akta Parafii pw. św. Michała Archanioła w Nockowej sygn. 122 - Akta Parafii pw. Zwiastowania NMP w Nowej Wsi Czudeckiej sygn. 123 - Akta Parafii pw. Dobrego Pasterza w Nowej Wsi Zaczerskiej sygn. 124 - Akta Parafii pw. świętych Apostołów Piotra i Pawła w Nowym Żmigrodzie sygn. 125 - Akta Parafii pw. Matki Bożej Fatimskiej w Olchowej sygn. 126 - Akta Parafii pw. Przemienienia Pańskiego w Osieku Jasielskim sygn. 127 - Akta Parafii pw. św. Stanisława Biskupa w Osobnicy sygn. 128 - Akta Parafii pw. Wniebowzięcia NMP w Ostrowach Tuszowskich sygn. 129 - Akta Parafii pw. Najświętszego Serca Pana Jezusa w Pagorzynie sygn. 130 - Akta Parafii pw. Miłosierdzia Bożego w Palikówce sygn. 131 - Akta Parafii pw. Matki Bożej Częstochowskiej w Polanach sygn. 132 - Akta Parafii pw. św. Mikołaja w Połomii sygn. 133 - Akta Parafii pw. św. Stanisława i św. Wojciecha w Porębach Dymarskich sygn. 134 - Akta Parafii pw. św. Józefa Rzemieślnika w Przedborzu sygn. 135 - Akta Parafii pw. św. Antoniego Padewskiego w Przewrotnem sygn. 136 - Akta Parafii pw. św. Kazimierza w Przybówce sygn. 137 - Akta Parafii pw. św. Józefa Robotnika w Pstrągowej sygn. 138 - Akta Parafii pw. św. Jana Chrzciciela w Pstrągówce sygn. 139 - Akta Rektoratu pw. św. Maksymiliana Kolbego w Rogoźnicy sygn. 140 - Akta Parafii pw. Przemienienia Pańskiego w Ropczycach sygn. 141 - Akta Parafii pw. św. Urszuli Ledóchowskiej w Ropczycach sygn. 142 - Akta Parafii pw. Świętej Rodziny w Ropczycach (Czekaj) sygn. 143 - Akta Parafii pw. św. Barbary w Ropczycach sygn. 144 - Akta Parafii pw. św. Anny w Ropczycach (Chechły) sygn. 145 - Akta Parafii pw. św. Michała Archanioła w Ropczycach (Witkowice) sygn. 146 - Akta Parafii pw. Miłosierdzia Bożego w Ropicy Polskiej sygn. 147 - Akta Parafii pw. św. Andrzeja Apostoła w Rożnowicach sygn. 148 - Akta Parafii pw. św. Teresy od Dzieciątka Jezus w Rudnej elkiej sygn. 149 - Akta Parafii pw. Bożego Ciała i Matki Bożej w Lourdes w Rzeszowie sygn. 150 - Akta Parafii pw. bł. Karoliny Kózka w Rzeszowie sygn. 151 - Akta Parafii pw. Chrystusa Króla w Rzeszowie sygn. 152 - Akta Parafii pw. Matki Bożej Królowej Polski w Rzeszowie (Garnizonowy) sygn. 153 - Akta Parafii pw. Matki Bożej Różańcowej w Rzeszowie sygn. 154 - Akta Parafii pw. Matki Bożej Saletyńskiej w Rzeszowie (Saletyni) sygn. 155 - Akta Parafii pw. Najświętszego Serca Pana Jezusa w Rzeszowie (Katedra) sygn. 156 - Akta Parafii pw. Narodzenia NMP w Rzeszowie (Staroniwa) sygn. 157 - Akta Parafii pw. Opatrzności Bożej w Rzeszowie (Salezjanie) sygn. 158 - Akta Parafii pw. Podwyższenia Krzyża Świętego w Rzeszowie sygn. 159 - Akta Parafii pw. św. Jacka w Rzeszowie (Dominikanie) 
sygn. 160 - Akta Rektoratu pw. św. Jadwigi Królowej w Rzeszowie sygn. 161 - Akta Parafii pw. św. Józefa w Rzeszowie (Staromieście) sygn. 162 - Akta Parafii pw. św. Józefa w Rzeszowie - Zwięczycy sygn. 163 - Akta Parafii pw. św. Józefa Kalasancjusza w Rzeszowie (Pijarzy) sygn. 164 - Akta Parafii pw. św. Józefa Sebastiana Pelczara w Rzeszowie sygn. 165 - Akta Parafii pw. św. Judy Tadeusza w Rzeszowie sygn. 166 - Akta Parafii pw. Świętego Krzyża w Rzeszowie sygn. 167 - Akta Parafii pw. św. Michała Archanioła w Rzeszowie sygn. 168 - Akta Parafii pw. św. Mikołaja w Rzeszowie - Przybyszówce sygn. 169 - Akta Parafii pw. św. Rocha w Rzeszowie - Słocinie sygn. 170 - Akta Parafii pw. Świętej Rodziny w Rzeszowie (Misjonarze Świętej Rodziny)

sygn. 171 - Akta Rektoratu pw. Świętej Trójcy w Rzeszowie sygn. 172 - Akta Parafii pw. św. Wojciecha i św. Stanisława w Rzeszowie (Fara) sygn. 173 - Akta Parafii pw. Wniebowzięcia NMP w Rzeszowie (Bernardyni) sygn. 174 - Akta Parafii pw. Wniebowzięcia NMP w Rzeszowie- Zalesiu sygn. 175 - Akta Parafii pw. św. Marii Magdaleny w Samoklęskach sygn. 176 - Akta Parafii pw. Narodzenia NMP w Sędziszowie Małopolskim sygn. 177 - Akta Parafii pw. św. Józefa Oblubieńca NMP w Sękowej sygn. 178 - Akta Parafii pw. św. Józefa w Siedliskach k. Rzeszowa sygn. 179 - Akta Parafii pw. św. Stanisława BM w Sieklówce sygn. 180 - Akta Parafii pw. św. Klemensa Papieża w Skalniku sygn. 181 - Akta Parafii pw. św. Józefa i św. św. Piotra i Pawła w Skołyszynie sygn. 182 - Akta Parafii pw. św. Katarzyny w Sławęcinie sygn. 183 - Akta Parafii pw. św. Michała Archanioła w Smerekowcu sygn. 184 - Akta Parafii pw. św. Jana Chrzciciela w Sokołowie Małopolskim sygn. 185 - Akta Parafii pw. św. Katarzyny w Starym Żmigrodzie sygn. 186 - Akta Parafii pw. św. Maksymiliana Kolbego w Stępinie sygn. 187 - Akta Parafii pw. Niepokalanego Serca NMP w Stobiernej sygn. 188 - Akta Parafii pw. Matki Bożej Nieustającej Pomocy w Straszydlu sygn. 189 - Akta Parafii pw. Matki Bożej Królowej Polski w Strażowie sygn. 190 - Akta Parafii pw. Niepokalanego Poczęcia NMP i Bożego Ciała w Strzyżowie sygn. 191 - Akta parafii pw. św. Józefa Sebastiana Pelczara w Strzyżowie sygn. 192 - Akta parafii pw. św. Michała Archanioła w Stykowie sygn. 193 - Akta Parafii pw. św. Marcina w Szebniach sygn. 194 - Akta Parafii pw. Matki Bożej Ostrobramskiej w Szufnarowej sygn. 195 - Akta Parafii pw. św. Anny w Święcanach sygn. 196 - Akta Parafii pw. Wniebowzięcia NMP w Świlczy sygn. 197 - Akta Parafii pw. Narodzenia NMP w Tarnowcu sygn. 198 - Akta Parafii pw. Matki Bożej Fatimskiej w Terliczce sygn. 199 - Akta Parafii pw. św. Wawrzyńca i Matki Bożej Niepokalanie Poczętej w Trzcianie sygn. 200 - Akta Parafii pw. Przemienienia Pańskiego i św. Doroty w Trzcinicy sygn. 201 - Akta Parafii pw. Opatrzności Bożej w Trzebosi 
sygn. 202 - Akta Parafii pw. św. Wojciecha i Niepokalanego Poczęcia NMP

w Trzebownisku

sygn. 203 - Akta Parafii pw. Matki Bożej Częstochowskiej w Trzebusce

sygn. 204 - Akta Parafii pw. św. Anny w Trzęsówce

sygn. 205 - Akta Parafii pw. Świętej Trójcy w Tyczynie

sygn. 206 - Akta Parafii pw. św. Jana Kantego w Ustrobnej

sygn. 207 - Akta Parafii pw. św. Wawrzyńca w Warzycach

sygn. 208 - Akta Parafii pw. św. Maksymiliana Kolbego w Weryni

sygn. 209 - Akta Parafii pw. Matki Bożej Królowej Polski w Widełce

sygn. 210 - Akta Parafii pw. Wniebowzięcia NMP w Wielopolu Skrzyńskim

sygn. 211 - Akta Parafii pw. NMP Królowej Świata w Wiśniowej

sygn. 212 - Akta Parafii pw. Świętej Trójcy i Podwyższenia Krzyża Świętego

w Woli Rafałowskiej

sygn. 213 - Akta Parafii pw. Matki Bożej Królowej Polski w Woli Zgłobieńskiej

sygn. 214 - Akta Parafii pw. św. Bartłomieja Ap. w Wójtowej

sygn. 215 - Akta Parafii pw. Matki Bożej Królowej Polski w Wólce Niedźwiedzkiej

sygn. 216 - Akta Parafii pw. św. Jadwigi Królowej w Wólce Podleśnej

sygn. 217 - Akta Parafii pw. Matki Bożej Różańcowej w Wysokiej Głogowskiej

sygn. 218 - Akta Parafii pw. św. Józefa w Wysokiej Strzyżowskiej

sygn. 219 - Akta Parafii pw. Matki Bożej Wspomożenia Wiernych w Wyżnem

sygn. 220 - Akta Parafii pw. Wszystkich Świętych w Zabierzowie

sygn. 221 - Akta Parafii pw. Matki Bożej Królowej Polski w Zaborowie

sygn. 222 - Akta Parafii pw. Matki Bożej Różańcowej w Zabratówce

sygn. 223 - Akta Parafii pw. Narodzenia NMP w Zaczerniu

sygn. 224 - Akta Parafii pw. Świętych Apostołów Piotra i Pawła w Zagorzycach

sygn. 225 - Akta Parafii pw. św. Jana Chrzciciela w Załężu k. Jasła

sygn. 226 - Akta Parafii pw. Matki Bożej Nieustającej Pomocy i św. Floriana

w Załężu k. Rzeszowa

sygn. 227 - Akta Parafii pw. Miłosierdzia Bożego w Zawadce

sygn. 228 - Akta Parafii pw. św. Andrzeja Ap. w Zgłobniu

sygn. 229 - Akta Parafii pw. św. Maksymiliana Kolbego w Żarnowej

sygn. 230 - Akta parafii pw. Przemienienia Pańskiego w Żyznowie

Zespół 6: Księgi Parafialne

sygn. 1 - Księgi parafii pw. Dobrego Pasterza w Babicy

sygn. 1/a - Księga inwentarzowa (ksero)

sygn. 1/b - Księga ochrzczonych [1945-1974, 1975- 2002 (ksero), 2003-2006]

sygn. 1/c - Księga zaślubionych [1953- 2002 (ksero), 2003-2006]

sygn. 1/d - Księga zmarłych [1946- 2002 (ksero), 2003-2006]

sygn. 2 - Księgi parafii pw. Nawiedzenia NMP w Baryczce

sygn. 2/a -Księga inwentarzowa [brak]

sygn. 2/b -Księga ochrzczonych [1992 - 2001 (ksero), 2003-2004]

sygn. 2/c - Księga zaślubionych [1992- 2002 (ksero), 2003-2004]

sygn. 2/d - Księga zmarłych [1992-2002 (ksero), 2003-2004] 
sygn. 3 - Księgi parafii pw. Imienia Maryi w Bączalu Dolny sygn. 3/a - Księga inwentarzowa [brak] sygn. 3/b - Księga ochrzczonych [1992-2001, 2002-2003, Bączal Dolny - Jabłonica 2001-2002 (ksero), 2004-2006]

sygn. 3/c - Księga zaślubionych [ 1992- 2001, 2002-2003, Bączal Dolny - Jabłonica 2001- 2002 (ksero), 2004-2006]

sygn. 3/d - Księga zmarłych [1992- 2001, 2002 - 2006]

sygn. 4 - Księgi parafii pw. św. Jacka w Będziemyślu

sygn. 4/a -Księga inwentarzowa [ksero]

sygn. 4/b -Księga ochrzczonych [1992 - 2002 (ksero), 2003-2006]

sygn. 4/c -Księga zaślubionych [1992- 2002 (ksero), 2003-2006]

sygn. 4/d -Księga zmarłych [1992-2002 (ksero), 2003-2006]

sygn. 5 - Księgi parafii pw. Miłosierdzia Bożego w Białej

sygn. 5/a - Księga inwentarzowa

sygn. 5/b/I - Księga ochrzczonych [1983-1997]

sygn. 5/b/II - Księga ochrzczonych [1997-2006]

sygn. 5/c/I - Księga zaślubionych [1983- 1996]

sygn. 5/c/II - Księga zaślubionych [1997-2006]

sygn. 5/d/I - Księga zmarłych [1983-1997]

sygn. 5/d/II - Księga zmarłych [1997-2006]

sygn. 5/e - Akta spraw

sygn. 6 - Księgi parafii pw. Bożego Ciała w Bieczu

sygn. 6/a - Księga inwentarzowa [brak]

sygn. 6/b - Księga ochrzczonych [ 1992-2007]

sygn. 6/c - Księga zaślubionych [1992-2007]

sygn. 6/d - Księga zmarłych [1992-2007]

sygn. 7 - Księgi parafii pw. św. Anny w Bieczu

sygn. 7/a - Księga inwentarzowa [nie ma]

sygn. 7/b - Księga ochrzczonych [1999-2006]

sygn. 7/c - Księga zaślubionych [1999- 2006]

sygn. 7/d - Księga zmarłych [ 1999- 2006]

sygn. 8 - Księgi parafii pw. Świętej Trójcy w Bieździedzy

sygn. 8/a - Księga inwentarzowa [stan 2003]

sygn. 8/b - Księga ochrzczonych [1990-2006]

sygn. 8/c - Księga zaślubionych [1990-2006]

sygn. 8/d - Księga zmarłych [1990-2006]

sygn. 9 - Księgi parafii pw. św. Michała Archanioła w Binarowej

sygn. 9/a - Księga inwentarzowa [stan z dnia 1711 2005]

sygn. 9/b - Księga ochrzczonych [1992-2006]

sygn. 9/c - Księga zaślubionych [1992-2006]

sygn. 9/d - Księga zmarłych [1992-2006]

sygn. 10 - Księgi parafii pw. Podwyższenia Krzyża Świętego w Bliziance

sygn. 10/a - Księga inwentarzowa [stan z 15 I 2005]

sygn. 10/b - Księga ochrzczonych [1992-2006]

sygn. 10/c - Księga zaślubionych [1992-2006] 
sygn. 10/d - Księga zmarłych [1992-2006]

sygn. 11 - Księgi parafii pw. Matki Bożej Nieustającej Pomocy w Błażkowej

sygn. 11/a - Księga inwentarzowa [brak]

sygn. 11/b - Księga ochrzczonych [1983-2003 (ksero), ]

sygn. 11/c - Księga zaślubionych [1982-2003 (ksero), ]

sygn. 11/d - Księga zmarłych [1983-2003 (ksero),]

sygn. 12 - Księgi parafii pw. Matki Bożej Królowej Polski w Błędowej Tyczyńskiej

sygn. 12/a - Księga inwentarzowa [stan z 1 IX 2005]

sygn. 12/b - Księga ochrzczonych [1992-2006]

sygn. 12/c - Księga zaślubionych [1992-2006]

sygn. 12/d - Księga zmarłych [1992-2006]

sygn. 13 - Księgi parafii pw. św. Wojciecha w Błędowej Zgłobieńskiej

sygn. 13/a - Księga inwentarzowa [ksero, 2003]

sygn. 13/b - Księga ochrzczonych [1995-2002, 2003-2006]

sygn. 13/c - Księga zaślubionych [1995-2002, 2003-2006]

sygn. 13/d - Księga zmarłych [1995-2002, 2003-2006]

sygn. 14 - Księgi parafii pw. św. Stanisława BM w Boguchwale

sygn. 14/a - Księga inwentarzowa [ksero; stan z 2003]

sygn. 14/b - Księga ochrzczonych [1984-2006]

sygn. 14/c - Księga zaślubionych [1986-2006]

sygn. 14/d - Księga zmarłych [1969-2006]

sygn. 15 - Księgi parafii pw. Matki Bożej Częstochowskiej w Borku Wielkim

sygn. 15/a - Księga inwentarzowa [jest, ksero, 2003]

sygn. 15/b - Księga ochrzczonych [1990-2006]

sygn. 15/c - Księga zaślubionych [1990-2006]

sygn. 15/d - Księga zmarłych [1990-2006]

sygn. 16 - Księgi parafii pw. św. Jana Chrzciciela w Bratkowicach

sygn. 16/a - Księga inwentarzowa [2003]

sygn. 16/b/I - Księga ochrzczonych [1971-1978]

sygn. 16/b/II - Księga ochrzczonych [1978-1991]

sygn. 16/b/III - Księga ochrzczonych [1991-2002]

sygn. 16/b/IV - Księga ochrzczonych [2003-2006]

sygn. 16/c/I - Księga zaślubionych [1971-2002]

sygn. 16/c/II - Księga zaślubionych [2003-2006]

sygn. 16/d/I - Księga zmarłych [1971-2002]

sygn. 16/d/II - Księga zmarłych [2003-2006]

sygn. 17 - Księgi parafii pw. św. Mikołaja w Brzezinach

sygn. 17/a - Księga inwentarzowa

sygn. 17/b - Księga ochrzczonych [1992-2002; 2003-2006]

sygn. 17/c - Księga zaślubionych [1992-2002; 2003-2006]

sygn. 17/d - Księga zmarłych [1992-2002; 2003-2006]

sygn. 18 - Księgi parafii pw. Znalezienia Krzyża Świętego w Brzostku

sygn. 18/a - Księga inwentarzowa [ksero, 2002]

sygn. 18/b/I - Księga ochrzczonych [1992-2003 (1996-2002 ksero)]

sygn. 18/b/II - Księga ochrzczonych [1996-2006] 
sygn. 18/c - Księga zaślubionych [1992-2006]

sygn. 18/d - Księga zmarłych [1992-2006]

sygn. 19 - Księgi parafii pw. św. Marii Magdaleny w Brzyskach

sygn. 19/a - Księga inwentarzowa [ksero, stan z 1995]

sygn. 19/b/I - Księga ochrzczonych [1989-1994]

sygn. 19/b/II - Księga ochrzczonych [1995-2002, 2003-2006]

sygn. 19/c - Księga zaślubionych [1992-2002 (ksero), 2003-2006]

sygn. 19/d - Księga zmarłych [1992-2002 (ksero), 2003-2006]

sygn. 20 - Księgi parafii pw. Niepokalanego Serca NMP w Budach Głogowskich

sygn. 20/a - Księga inwentarzowa [ksero, stan z 2003]

sygn. 20/b - Księga ochrzczonych [1985-1994, 1994-2006]

sygn. 20/c - Księga zaślubionych [1979-2000, 2001-2006]

sygn. 20/d - Księga zmarłych [1979-2002, 2003-2006]

sygn. 21 - Księgi parafii pw. Matki Bożej Śnieżnej w Budziwoju

sygn. 21/a - Księga inwentarzowa [ksero, 2001]

sygn. 21/b/I - Księga ochrzczonych [1989-1994]

sygn. 21/b/II - Księga ochrzczonych [1995 - 2002; 2003-2006]

sygn. 21/c - Księga zaślubionych [1991-2002; 2003-2006]

sygn. 21/d - Księga zmarłych [1988-2002; 2003-2006]

sygn. 22 - Księgi parafii pw. św. Franciszka z Asyżu w Bystrzycy

sygn. 22/a - Księga inwentarzowa [ksero - 1988, akt. 2001]

sygn. 22/b/I - Księga ochrzczonych [1985-2002, 2004-2006]

sygn. 22/b/II - Księga ochrzczonych [Wiśniowa (1985-1993)]

sygn. 22/b/III - Księga ochrzczonych [Wiśniowa (1993-2003)]

sygn. 22/c/I - Księga zaślubionych [1985-2003, 2004-2006]

sygn. 22/c/II - Księga zaślubionych [Wiśniowa (1985-2003)]

sygn. 22/d/I - Księga zmarłych [1985-2003, 2004-2006]

sygn. 22/d/II - Księga zmarłych [Wiśniowa (1985-2003)]

sygn. 23 - Księgi parafii pw. św. Maksymiliana Kolbego w Bziance

sygn. 23/a - Księga inwentarzowa [ksero, stan z 2002]

sygn. 23/b - Księga ochrzczonych [1987-2006]

sygn. 23/c - Księga zaślubionych [1987-2006]

sygn. 23/d - Księga zmarłych [1987-2006]

sygn. 24 - Księgi parafii pw. Matki Bożej Łaskawej w Chmielniku Rzeszowskim

sygn. 24/a - Księga inwentarzowa [ksero, 2002]

sygn. 24/b - Księga ochrzczonych [1991-2002; 2003-2006]

sygn. 24/c - Księga zaślubionych [1991-2002; 2003-2006]

sygn. 24/d - Księga zmarłych [1991-2002; 2003-2006]

sygn. 25 - Księgi parafii pw. św. Michała Archanioła w Cieklinie

sygn. 25/a - Księga inwentarzowa [brak]

sygn. 25/b - Księga ochrzczonych [1976-1993]

sygn. 25/c - Księga zaślubionych [1976-2002, 1998- 2006]

sygn. 25/d - Księga zmarłych [1966- 2006]

sygn. 26 - Księgi parafii pw. Przemienienia Pańskiego w Cmolasie 
sygn. 26/a - Księga inwentarzowa [ksero, stan z 2003]

sygn. 26/b - Księga ochrzczonych [1992-2003 (ksero), 2004-2006]

sygn. 26/c - Księga zaślubionych [1980-2003 (ksero), 2004-2006]

sygn. 26/d - Księga zmarłych [1992-2003 (ksero), 2004-2006]

sygn. 27 - Księgi parafii pw. św. Stanisława BM w Czarnej Sędziszowskiej

sygn. 27/a - Księga inwentarzowa

sygn. 27/b/I - Księga ochrzczonych - Czarna [1966-1995]

sygn. 27/b/II - Księga ochrzczonych - Czarna [1996-2002]

sygn. 27/b/III - Księga ochrzczonych - Cierpisz [1966-2002]

sygn. 27/b/IV - Księga ochrzczonych - Krzywa [1966-2002]

sygn. 27/b/V - Księga ochrzczonych - Ruda [1966-2002]

sygn. 27/b/VI - Księga ochrzczonych [2003-2006]

sygn. 27/c/I - Księga zaślubionych - Czarna [1966-2002]

sygn. 27/c/II - Księga zaślubionych - Krzywa [1966-2002]

sygn. 27/c/III - Księga zaślubionych - Ruda i Cierpisz [1966-2002]

sygn. 27/c/IV - Księga zaślubionych [2003-2006]

sygn. 27/d/I - Księga zmarłych - Czarna [1966-2002]

sygn. 27/d/II - Księga zmarłych - Cierpisz [1966-2002]

sygn. 27/d/III - Księga zmarłych - Krzywa [1966-2002]

sygn. 27/d/IV - Księga zmarłych - Ruda [1966-2002]

sygn. 27/d/V - Księga zmarłych [2003-2006]

sygn. 28 - Księgi parafii pw. św. Maksymiliana Kolbego w Czeluśnicy

sygn. 28/a - Księga inwentarzowa [stan z 2003]

sygn. 28/b - Księga ochrzczonych [1988-2003-2006]

sygn. 28/c - Księga zaślubionych [1973-2003-2006]

sygn. 28/d - Księga zmarłych [1973-2003-2006]

sygn. 29 - Księgi parafii pw. Świętej Trójcy w Czudcu

sygn. 29/a - Księga inwentarzowa [stan z 2003]

sygn. 29/b/I - Księga ochrzczonych [1968-1993]

sygn. 29/b/II - Księga ochrzczonych [1993-2002]

sygn. 29/b/III - Księga ochrzczonych [2003-2006]

sygn. 29/c - Księga zaślubionych [1968-2003-2006]

sygn. 29/d - Księga zmarłych [1969-2003-2006]

sygn. 30 - Księgi parafii pw. Matki Bożej Królowej Polski w Dąbrowie

sygn. 30/a - Ksiega inwentarzowa [ksero, 2003]

sygn. 30/b - Księga ochrzczonych [1970-2002; 2003-2006]

sygn. 30/c - Księga zaślubionych [1970-2002; 2003-2006]

sygn. 30/d - Księga zmarłych [1970-2002; 2003-2006]

sygn. 31 - Księgi parafii pw. św. Judy Tadeusza w Dąbrówce-Gamrat

sygn. 31/a - Księga inwentarzowa [stan z 2004]

sygn. 31/b - Księga ochrzczonych [1975-2003-2006]

sygn. 31/c - Księga zaślubionych [1975-2003-2006]

sygn. 31/d - Księga zmarłych [1975-2003-2006]

sygn. 32 - Księgi parafii pw. Matki Bożej Niepokalanej w Desznicy

sygn. 32/a - Księga inwentarzowa [ksero, stan z 1985, aktualizowany do 2003] 
sygn. 32/b - Księga ochrzczonych [1957-2002 (ksero); 2003-2004] sygn. 32/c - Księga zaślubionych [1957-2002 (ksero); 2003-2004] sygn. 32/d - Księga zmarłych [1957-2002 (ksero); 2003-2004] sygn. 33 - Księgi parafii pw. św. Bartłomieja Ap. w Dębowcu sygn. 33/a - Księga inwentarzowa [stan z 1994] sygn. 33/b - Księga ochrzczonych [1992-2006] sygn. 33/c - Księga zaślubionych [1992-2006] sygn. 33/d - Księga zmarłych [1992-2003, 2004-2006] sygn. 34 - Księgi parafii pw. św. Stanisława BM w Dobrzechowie sygn. 34/a - Księga inwentarzowa [stan z 1987, aktualizowany do 2003] sygn. 34/b - Księga ochrzczonych [1979-2002, 2003-2006] sygn. 34/c - Księga zaślubionych [1978-2002, 2003-2006] sygn. 34/d - Księga zmarłych [1984-2002, 2003-2006] sygn. 35 - Księgi parafii pw. Miłosierdzia Bożego w Domatkowie sygn. 35/a - Księga inwentarzowa [do 2002] sygn. 35/b/I - Księga ochrzczonych [1991-2002] sygn. 35/b/II - Księga ochrzczonych [2003-2006] sygn. 35/c - Księga zaślubionych [1991-2006] sygn. 35/d - Księga zmarłych [1992-2006] sygn. 36 - Księgi parafii pw. Dobrego Pasterza w Faliszówce sygn. 36/a - Księga inwentarzowa [ksero, 2002] sygn. 36/b - Księga ochrzczonych [2000-2003 (ksero), 2004-2006] sygn. 36/c - Księga zaślubionych [2000-2003 (ksero), 2004-2006] sygn. 36/d - Księga zmarłych [2000-2003 (ksero), 2004-2006] sygn. 37 - Księgi parafii pw. Najświętszego Serca Pana Jezusa w Foluszu sygn. 37/a - Księga inwentarzowa [2002 (ksero)] sygn. 37/b - Księga ochrzczonych [1995-2003-2006] sygn. 37/c - Księga zaślubionych [1996-2003-2006] sygn. 37/d - Księga zmarłych [1996-2003-2006] sygn. 38 - Księgi parafii pw. Narodzenia NMP we Frysztaku sygn. 38/a - Księga inwentarzowa sygn. 38/b/I - Księga ochrzczonych [1974-1984] sygn. 38/b/II - Księga ochrzczonych [1985-1997] sygn. 38/b/III - Księga ochrzczonych [1998-2002] sygn. 38/b/IV - Księga ochrzczonych [2003-2006] sygn. 38/c - Księga zaślubionych [1974-2003-2006] sygn. 38/d - Księga zmarłych [1976-2003-2006] sygn. 39 - Księgi parafii pw. św. Maksymiliana Kolbego w Gliniku sygn. 39/a - Księga inwentarzowa [ksero, stan z 2003] sygn. 39/b/I - Księga ochrzczonych [1980-1988] sygn. 39/b/II - Księga ochrzczonych [1988-2002] sygn. 39/b/III - Księga ochrzczonych [2003-2006] sygn. 39/c/I - Księga zaślubionych [1981-2002] sygn. 39/c/II - Księga zaślubionych [2003-2006] sygn. 39/d/I - Księga zmarłych [1982-2002] 
sygn. 39/d/II - Księga zmarłych [2003-2006]

sygn. 40 - Księgi parafii pw. św. Józefa Robotnika w Gliniku Polskim

sygn. 40/a - Księga inwentarzowa [stan z 2003]

sygn. 40/b - Księga ochrzczonych [1992-2006]

sygn. 40/c - Księga zaślubionych [1992-2006]

sygn. 40/d - Księga zmarłych [1992-2006]

sygn. 41 - Księgi parafii pw. Matki Bożej Częstochowskiej w Gliniku Zaborowskim

sygn. 41/a - Księga inwentarzowa [ksero]

sygn. 41/b - Księga ochrzczonych [1992-2006]

sygn. 41/c - Księga zaślubionych [1992-2006]

sygn. 41/d - Księga zmarłych [1992-2006]

sygn. 42 - Księgi parafii pw. Narodzenia św. Jana Chrzciciela w Gładyszowie

sygn. 42/a - Księga inwentarzowa [stan z 2007]

sygn. 42/b - Księga ochrzczonych [1983-2003 (ksero), 2004-2006]

sygn. 42/c - Księga zaślubionych [1983-2003 (ksero), 2004-2006]

sygn. 42/d - Księga zmarłych [1983-2003 (ksero), 2004-2006]

sygn. 43 - Księgi parafii pw. Świętej Trójcy w Głogowie Małopolskim

sygn. 43/a - Księga inwentarzowa [2003]

sygn. 43/b/I - Księga ochrzczonych [1979-1988]

sygn. 43/b/II - Księga ochrzczonych [1971-1994 (ksero)]

sygn. 43/b/III - Księga ochrzczonych [1995-2004 (ksero), 2005-2006]

sygn. 43/c/I - Księga zaślubionych [1985-1995 (ksero)]

sygn. 43/c/II - Księga zaślubionych [1991-2004 (ksero), 2005-2006]

sygn. 43/d/I - Księga zmarłych [1986-1995]

sygn. 43/d/II - Księga zmarłych [1975-2004 (ksero), 2005-2006]

sygn. 43A - Księgi parafii pw. św. Józefa w Głogowie Małopolskim - Niwa

sygn. 43A/a - Księga inwentarzowa [brak]

sygn. 43A/b - Księga ochrzczonych [2006]

sygn. $43 \mathrm{~A} / \mathrm{c}$ - Księga zaślubionych

sygn. $43 \mathrm{~A} / \mathrm{d}$ - Księga zmarłych

sygn. 44 - Księgi parafii pw. św. Maksymiliana Kolbego w Głojscach

sygn. 44/a - Księga inwentarzowa

sygn. 44/b - Księga ochrzczonych [1972-2002, 2003-2006]

sygn. 44/c - Księga zaślubionych [1972-2002, 2003-2006]

sygn. 44/d - Księga zmarłych [1972-2002, 2003-2006]

sygn. 45 - Księgi parafii pw. św. Krzysztofa w Godowej

sygn. 45/a - Księga inwentarzowa [stan z 2006]

sygn. 45/b - Księga ochrzczonych [1992-2006]

sygn. 45/c - Księga zaślubionych [1992-2006]

sygn. 45/d - Księga zmarłych [1992-2006]

sygn. 46 - Księgi parafii pw. św. Katarzyny w Gogołowie

sygn. 46/a - Księga inwentarzowa [brak]

sygn. 46/b/I - Księga ochrzczonych [1984-2002]

sygn. 46/b/II - Księga ochrzczonych [2003-2006]

sygn. 46/c/I - Księga zaślubionych [1973-2002] 
sygn. 46/c/II - Księga zaślubionych [2003-2006]

sygn. 46/d/I - Księga zmarłych [1973-2002]

sygn. 46/d/II - Księga zmarłych [2003-2006]

sygn. 47 - Księgi parafii pw. Matki Bożej Nieustającej Pomocy w Gorlicach -

Gliniku Mariampolskim

sygn. 47/a - Księga inwentarzowa [stan z 2004]

sygn. 47/b - Księga ochrzczonych [1992-2007]

sygn. 47/c - Księga zaślubionych [1992-2007]

sygn. 47/d - Księga zmarłych [1992-2007]

sygn. 48 - Księgi parafii pw. Narodzenia NMP w Gorlicach

sygn. 48/a - Księga inwentarzowa [stan z 2004]

sygn. 48/b - Księga ochrzczonych [1992-2006]

sygn. 48/c/I - Księga zaślubionych [1992-1997]

sygn. 48/c/II - Księga zaślubionych [1998-2006]

sygn. 48/d/I - Księga zmarłych [1992-1997]

sygn. 48/d/II - Księga zmarłych [1998-2006]

sygn. 49 - Księgi parafii pw. św. Andrzeja Boboli w Gorlicach

sygn. 49/a - Księga inwentarzowa [stan z 1993 i 2004]

sygn. 49/b/I - Księga ochrzczonych [1983-1997]

sygn. 49/b/II - Księga ochrzczonych [1998-2008]

sygn. 49/c/I - Księga zaślubionych [1983-2002]

sygn. 49/c/II - Księga zaślubionych [2003-2008]

sygn. 49/d/I - Księga zmarłych [1983-2002]

sygn. 49/d/II - Księga zmarłych [1997-2008]

sygn. 50 - Księgi parafii pw. św. Jadwigi Królowej w Gorlicach

sygn. 50/a - Księga inwentarzowa [brak]

sygn. 50/b - Księga ochrzczonych [1999-2003, 2004-2006]

sygn. 50/c - Księga zaślubionych [1999-2003, 2004-2006]

sygn. 50/d - Księga zmarłych [1999-2003, 2004-2006]

sygn. 51 - Księgi parafii pw. św. Jakuba Starszego Ap. w Górze Ropczyckiej

sygn. 51/a - Księga inwentarzowa [brak]

sygn. 51/b/I - Księga ochrzczonych - Góra Ropczycka [1991-2002]

sygn. 51/b/II - Księga ochrzczonych - Gnojnica [1991-2002]

sygn. 51/b/I - Księga ochrzczonych - Zagórzyce [1991-2002]

sygn. 51/b/IV - Księga ochrzczonych [2003-2006]

sygn. 51/c/I - Księga zaślubionych - Góra Ropczycka [1992-2002]

sygn. 51/c/II - Księga zaślubionych - Gnojnica [1992-2002]

sygn. 51/c/III - Księga zaślubionych - Zagórzyce [1992-2002]

sygn. 51/c/IV - Księga zaślubionych [2003-2006]

sygn. 51/d/I - Księga zmarłych - Góra Ropczycka [1991-2002]

sygn. 51/d/II - Księga zmarłych - Gnojnica [1991-2002]

sygn. 51/d/III - Księga zmarłych -Zagórzyce [1991-2002]

sygn. 51/d/IV - Księga zmarłych [2003-2006]

sygn. 52 - Księgi parafii pw. Ofiarowania NMP w Górnie

sygn. 52/a - Księga inwentarzowa [ksero, 2001] 
sygn. 52/b - Księga ochrzczonych [Markowizna 1981-2006; Górno 1987-2006] sygn. 52/c - Księga zaślubionych [1982-2006]

sygn. 52/d - Księga zmarłych [1992-2006]

sygn. 53 - Księgi parafii pw. Niepokalanego Serca NMP i św. Stanisława Kostki

w Grodzisku Strzyżowskim

sygn. 53/a - Księga inwentarzowa [ksero, stan z 2002]

sygn. 53/b - Księga ochrzczonych [1989-2002, 2003-2004]

sygn. 53/c - Księga zaślubionych [1989-2002, 2003-2004]

sygn. 53/d - Księga zmarłych [1989-2002, 2003-2004]

sygn. 54 - Księgi parafii pw. św. Antoniego Padewskiego w Gwoźnicy Górnej

sygn. 54/a - Księga inwentarzowa [stan z 2002]

sygn. 54/b - Księga ochrzczonych [1990-2002, 2003-2005]

sygn. 54/c - Księga zaślubionych [1990-2002, 2003-2005]

sygn. 54/d - Księga zmarłych [1990-2002, 2003-2005]

sygn. 55 - Księgi parafii pw. św. Doroty w Harklowej

sygn. 55/a - Księga inwentarzowa [stan z 2003]

sygn. 55/b - Księga ochrzczonych [1992-2006]

sygn. 55/c/I - Księga zaślubionych [1992-2002]

sygn. 55/c/II - Księga zaślubionych [2003-2006]

sygn. 55/d - Księga zmarłych [1992-2006]

sygn. 56 - Księgi parafii pw. Matki Bożej Niepokalanej w Hermanowej

sygn. 56/a - Księga inwentarzowa [ksero, stan z 2001]

sygn. 56/b - Księga ochrzczonych [1982-2002, 2003 (ksero), 2004-2006]

sygn. 56/c - Księga zaślubionych [1985-2002, 2003 (ksero), 2004-2006]

sygn. 56/d - Księga zmarłych [1985-2002, 2003 (ksero), 2004-2006]

sygn. 57 - Księgi parafii pw. Matki Bożej Królowej w Jabłonicy

sygn. 57/a - Księga inwentarzowa [ksero, stan z 2003 r.]

sygn. 57/b - Księga ochrzczonych [2003-2006]

sygn. 57/c - Księga zaślubionych [2003-2006]

sygn. 57/d - Księga zmarłych [2003-2006]

sygn. 58 - Księgi parafii pw. Zwiastowania Pańskiego w Januszkowicach

sygn. 58/a - Księga inwentarzowa [1995]

sygn. 58/b/I - Księga ochrzczonych [1983-1995]

sygn. 58/b/II - Księga ochrzczonych [1995-2002, 2003-2006]

sygn. 58/c - Ksiegga zaślubionych [1967-2002, 2003-2006]

sygn. 58/d - Księga zmarłych [1983-2002, 2003-2006]

sygn. 59 - Księgi parafii pw. św. Stanisława Kostki w Jasionce

sygn. 59/a - Księga inwentarzowa [ksero]

sygn. 59/b - Księga ochrzczonych [1975-2002, 2003-2006]

sygn. 59/c - Księga zaślubionych [1976-2002, 2003-2006]

sygn. 59/d - Księga zmarłych [1975-2002, 2003-2006]

sygn. 60 - Księgi parafii pw. Chrystusa Króla w Jaśle (Brzyszczki)

sygn. 60/a - Księga inwentarzowa [2003]

sygn. 60/b - Księga ochrzczonych [1988-2002, 2003-2008]

sygn. 60/c - Księga zaślubionych [1988-2002, 2003-2008] 
sygn. 60/d - Księga zmarłych [1988-2002, 2003-2008]

sygn. 61 - Księgi parafii pw. Dobrego Pasterza w Jaśle (Sobniów)

sygn. 61/a - Księga inwentarzowa

sygn. 61/b - Księga ochrzczonych [1987-2006]

sygn. 61/c - Księga zaślubionych [1987-2003, 2005-2006]

sygn. 61/d - Księga zmarłych [1987-2003, 2005-2006]

sygn. 62 - Księgi parafii pw. Matki Bożej Częstochowskiej w Jaśle

sygn. 62/a - Księga inwentarzowa [ksero, 2003]

sygn. 62/b - Księga ochrzczonych [1996-2006]

sygn. 62/c - Księga zaślubionych [1996-2006]

sygn. 62/d - Księga zmarłych [1996-2006]

sygn. 63 - Księgi parafii pw. Matki Bożej Królowej Świata w Jaśle (Niegłowice)

sygn. 63/a - Księga inwentarzowa [opis kościoła z 2008 r.]

sygn. 63/b - Księga ochrzczonych [1992-2003, 2000-2007]

sygn. 63/c - Księga zaślubionych [2000-2007]

sygn. 63/d - Księga zmarłych [1957-2007]

sygn. 64 - Księgi parafii pw. Miłosierdzia Bożego w Jaśle

sygn. 64/a - Księga inwentarzowa [2005]

sygn. 64/b - Księga ochrzczonych [1982-2003-2006]

sygn. 64/c - Księga zaślubionych [1982-2003-2006]

sygn. 64/d - Księga zmarłych [1982-2003-2006]

sygn. 65 - Księgi parafii pw. Najświętszego Serca Pana Jezusa i Niepokalanego

Serca NMP w Jaśle (Górka)

sygn. 65/a - Księga inwentarzowa [2005]

sygn. 65/b - Księga ochrzczonych [1975-2002, 2003-2006]

sygn. 65/c - Księga zaślubionych [1975-2002, 2003-2006]

sygn. 65/d - Księga zmarłych [1975-2002, 2003-2006]

sygn. 66 - Księgi parafii pw. św. Antoniego w Jaśle (Franciszkanie)

sygn. 66/a - Księga inwentarzowa [brak]

sygn. 66/b/I - Księga ochrzczonych [1969-1975]

sygn. 66/b/II - Księga ochrzczonych [1975-1979]

sygn. 66/b/III - Księga ochrzczonych [1980-1983]

sygn. 66/b/IV - Księga ochrzczonych [1983-1987]

sygn. 66/b/V - Księga ochrzczonych [1987-1991]

sygn. 66/b/VI - Księga ochrzczonych [1991-1997]

sygn. 66/b/VII - Księga ochrzczonych [1997-2006]

sygn. 66/c/I - Księga zaślubionych [1969-1979]

sygn. 66/c/II - Księga zaślubionych [1980-1988]

sygn. 66/c/III - Księga zaślubionych [1988-1994]

sygn. 66/c/IV - Księga zaślubionych [1995-2006]

sygn. 66/d/I - Księga zmarłych [1969-1987]

sygn. 66/d/II - Księga zmarłych [1987-1998]

sygn. 66/d/III - Księga zmarlych [1998-2006]

sygn. 67 - Księgi parafii pw. św. Stanisława BM w Jaśle

sygn. 67/a - Księga inwentarzowa [stan 2003roku] 
sygn. 67/b/I - Księga ochrzczonych [1971-1987]

sygn. 67/b/II - Księga ochrzczonych [1987-1994]

sygn. 67/b/III - Księga ochrzczonych [1994-2002]

sygn. 67/b/IV - Księga ochrzczonych [2003-2006]

sygn. 67/c/I - Księga zaślubionych [1971-2002]

sygn. 67/c/II - Księga zaślubionych [2003-2006]

sygn. 67/d/I - Księga zmarłych [1971-2000]

sygn. 67/d/II - Księga zmarłych [2001-2006]

sygn. 68 - Księgi parafii pw. Wniebowzięcia NMP w Jaśle (Fara)

sygn. 68/a - Księga inwentarzowa [brak]

sygn. 68/b/I - Księga ochrzczonych [1982-1987]

sygn. 68/b/II - Księga ochrzczonych [1987-1997]

sygn. 68/b/III - Księga ochrzczonych [1998-2006]

sygn. 68/c/I - Księga zaślubionych [1968-1985]

sygn. 68/c/II - Księga zaślubionych [1986-2006]

sygn. 68/d/I - Księga zmarłych [1983-1998]

sygn. 68/d/II - Księga zmarłych [1999-2006]

sygn. 69 - Księgi parafii pw. Podwyższenia Krzyża Świętego w Jaszczwi

sygn. 69/a - Księga inwentarzowa [brak]

sygn. 69/b/I - Księga ochrzczonych [1992-2002]

sygn. 69/b/II - Księga ochrzczonych [2003-2006]

sygn. 69/c - Księga zaślubionych [1992-2003-2006]

sygn. 69/d - Księga zmarłych [1983-2003-2006]

sygn. 70 - Księgi Rektoratu pw. Matki Bożej Wspomożenia Wiernych w Jawor-

niku Niebyleckim

sygn. 70/a - Księga inwentarzowa [ksero, 1999]

sygn. 70/b - Księga ochrzczonych [1998-2006]

sygn. 70/c - Księga zaślubionych [1999-2006]

sygn. 70/d - Księga zmarłych [1998-2006]

sygn. 71 - Księgi parafii pw. Najświętszego Serca Jezusowego w Kamieniu

sygn. 71/a - Księga inwentarzowa [ksero, stan z 1994roku]

sygn. 71/b/I - Księga ochrzczonych [1992-2002 (ksero)]

sygn. 71/b/II - Księga ochrzczonych [2003-2006]

sygn. 71/c/I - Księga zaślubionych [1992-2002 (ksero)]

sygn. 71/c/II - Księga zaślubionych [2003-2006]

sygn. 71/d/I - Księga zmarłych [1992-2002 (ksero)]

sygn. 71/d/II - Księga zmarłych [2003-2006]

sygn. 72 - Księgi parafii pw. Podwyższenia Krzyża Świętego w Kamionce

sygn. 72/a - Księga inwentarzowa [stan z 2007roku]

sygn. 72/b - Księga ochrzczonych [1966-2002]

sygn. 72/b/II - Księga ochrzczonych [2003-2006]

sygn. 72/c - Księga zaślubionych [1971-2002]

sygn. 72/c/II - Księga zaślubionych [2003-2006]

sygn. 72/d - Księga zmarłych [1966-2002]

sygn. 72/d/II - Księga zmarłych [2003-2006] 
sygn. 73 - Księgi parafii pw. Podwyższenia Krzyża Świętego w Kawęczynie sygn. 73/a - Księga inwentarzowa [stan z 2006roku] sygn. 73/b - Księga ochrzczonych [1987-2006] sygn. 73/c - Księga zaślubionych [1994-2006] sygn. 73/d - Księga zmarłych [1994-2006] sygn. 74 - Księgi parafii pw. Matki Bożej Królowej Polski w Kątach sygn. 74/a - Księga inwentarzowa [ksero, 2003roku] sygn. 74/b - Księga ochrzczonych [1987-2002; 2003-2006] sygn. 74/c - Księga zaślubionych [1987-2002; 2003-2006] sygn. 74/d - Księga zmarłych [1987-2002; 2003-2006] sygn. 75 - Księgi parafii pw. Wniebowstąpienia Pańskiego w Kielnarowej sygn. 75/a - Księga inwentarzowa [ksero, stan z 2002roku] sygn. 75/b - Księga ochrzczonych [1992-2002, 2003-2004] sygn. 75/c - Księga zaślubionych [1992-2002, 2003-2004] sygn. 75/d - Księga zmarłych [1992-2002, 2003-2004] sygn. 76 - Księgi parafii pw. św. Maksymiliana Kolbego w Klęczanach sygn. 76/a - Księga inwentarzowa [2003] sygn. 76/b - Księga ochrzczonych [1973-2006] sygn. 76/c - Księga zaślubionych [1973-2006] sygn. 76/d - Księga zmarłych [1946-2006] sygn. 76A - Księgi parafii pw. Matki Bożej Saletyńskiej w Klęczanach k. Biecza sygn. 76A/a - Księga inwentarzowa [2006] sygn. 76A/b - Księga ochrzczonych [2005-2006]

sygn. 76A/c - Księga zaślubionych [2005-2006] sygn. 76A/d - Księga zmarłych [2005-2006] sygn. 77 - Księgi parafii pw. św. Jana Chrzciciela w Kobylance sygn. 77/a - Księga inwentarzowa [parafia zakonna] sygn. 77/b - Księga ochrzczonych [1992-2003-2006] sygn. 77/c - Księga zaślubionych [1992-2003-2006] sygn. 77/d - Księga zmarłych [1992-2003-2006] sygn. 78 - Księgi parafii pw. Matki Bożej Wspomożenia Wiernych w Kolbuszowej sygn. 78/a - Księga inwentarzowa [2007] sygn. 78/b - Księga ochrzczonych [1995-2006] sygn. 78/c - Księga zaślubionych [1995-2006] sygn. 78/d - Księga zmarłych [1995-2006] sygn. 79 - Księgi parafii pw. św. Brata Alberta w Kolbuszowej sygn. 79/a - Księga inwentarzowa [ksero] sygn. 79/b - Księga ochrzczonych [1995-2006] sygn. 79/c - Księga zaślubionych [1996-2006] sygn. 79/d - Księga zmarłych [1996-2006] sygn. 80 - Księgi parafii pw. Wszystkich Świętych w Kolbuszowej (Fara) sygn. 80/a - Księga inwentarzowa [ksero, 2003] sygn. 80/b - Księga ochrzczonych [1992-2007] sygn. 80/c - Księga zaślubionych [1992-2007] sygn. 80/d - Księga zmarłych [1992-2007] 
sygn. 81 - Księgi parafii pw. św. Anny w Kołaczycach

sygn. 81/a - Księga inwentarzowa [brak]

sygn. 81/b - Księga ochrzczonych [1990-2002 (ksero), 2003-2006]

sygn. 81/c - Księga zaślubionych [1990-2002 (ksero), 2003-2006]

sygn. 81/d - Księga zmarłych [1990-2002 (ksero), 2003-2006]

sygn. 82 - Księgi parafii pw. Najświętszego Serca Jezusowego w Kosowach

sygn. 82/a - Księga inwentarzowa [brak]

sygn. 82/b/I - Księga ochrzczonych [1983-2000]

sygn. 82/b/II - Księga ochrzczonych [2001-2006]

sygn. 82/c - Księga zaślubionych [1982-2006]

sygn. 82/d/I - Księga zmarłych [1983-1993]

sygn. 82/d/II - Księga zmarłych [1994-2006]

sygn. 83 - Księgi parafii pw. Niepokalanego Serca NMP w Krasnej

sygn. 83/a - Księga inwentarzowa

sygn. 83/b - Księga ochrzczonych [1992-2002 (ksero), 2003-2006]

sygn. 83/c - Księga zaślubionych [1985-2002 (ksero), 2003-2006]

sygn. 83/d - Księga zmarłych [1951-2002 (ksero), 2003-2006]

sygn. 84 - Księgi parafii pw. Wniebowzięcia NMP w Krasnem

sygn. 84/a - Księga inwentarzowa [ksero]

sygn. 84/b - Księga ochrzczonych [1992-2002, 2003-2006]

sygn. 84/c - Księga zaślubionych [1970-2002, 2003-2006]

sygn. 84/d/I - Księga zmarłych [1970-1983]

sygn. 84/d/II - Księga zmarłych [1983-2002]

sygn. 84/d/III - Księga zmarlych [2003-2006]

sygn. 85 - Księgi parafii pw. św. Maksymiliana Kolbego w Krempnej

sygn. 85/a - Księga inwentarzowa [brak]

sygn. 85/b - Księga ochrzczonych [1969-1982 (ksero), 1992-2007]

sygn. 85/c - Księga zaślubionych [1969-2002 (ksero), 1992-2007]

sygn. 85/d - Księga zmarłych [1969-2002 (ksero), 1992-2007]

sygn. 86 - Księgi parafii pw. Matki Bożej Królowej Polski w Krygu

sygn. 86/a - Księga inwentarzowa [2006]

sygn. 86/b - Księga ochrzczonych [1992-2006]

sygn. 86/c - Księga zaślubionych [1992-2006]

sygn. 86/d - Księga zmarłych [1992-2006]

sygn. 87 - Księgi parafii pw. św. Maksymiliana Kolbego w Krzywej Wsi - Podlesiu

sygn. 87/a - Księga inwentarzowa [ksero, stan z 2004roku]

sygn. 87/b/I - Księga ochrzczonych [1987-2000]

sygn. 87/b/II - Księga ochrzczonych [2000-2006]

sygn. 87/c/I - Księga zaślubionych [1987 - 2002]

sygn. 87/c/II - Księga zaślubionych [2003-2006]

sygn. 87/d/I - Księga zmarłych [1987-2002]

sygn. 87/d/II - Księga zmarłych [2003-2006]

sygn. 88 - Księgi parafii pw. św. Jana Chrzciciela w Kupnie

sygn. 88/a - Księga inwentarzowa [ksero, 2003]

sygn. 88/b/I - Księga ochrzczonych [1990-2002 (ksero), 2003-2006] 
sygn. 88/b/II - Księga ochrzczonych - Poręby Kupieńskie [1990-2002 (ksero), 2003-2006]

sygn. 88/c - Księga zaślubionych [1990-2002 (ksero), 2003-2006]

sygn. 88/d/I - Księga zmarłych [1990-2002 (ksero), 2003-2006]

sygn. 88/d/II - Księga zmarłych - Poręby Kupieńskie [1990-2002 (ksero), 20032006]

sygn. 89 - Księgi parafii pw. Narodzenia NMP w Libuszy

sygn. 89/a - Księga inwentarzowa

sygn. 89/b/I - Księga ochrzczonych [1992-2002]

sygn. 89/b/II - Księga ochrzczonych [2003-2006]

sygn. 89/c/I - Księga zaślubionych [1992-2002]

sygn. 89/c/II - Księga zaślubionych [2003-2006]

sygn. 89/d/I - Księga zmarłych [1992-2002]

sygn. 89/d/II - Księga zmarłych [2003-2006]

sygn. 4/90 - Księgi parafii pw. Wniebowzięcia NMP w Lipinkach

sygn. 90/a - Księga inwentarzowa [stan z 2003roku]

sygn. 90/b - Księga ochrzczonych [1992-2005]

sygn. 90/c - Księga zaślubionych [1992-2005]

sygn. 90/d - Księga zmarłych[1992-2005]

sygn. 90A - Księgi parafii pw. Matki Bożej Królowej Polski w Lisowie

sygn. 90A/a - Księga inwentarzowa

sygn. 90A/b - Księga ochrzczonych [2005-2006]

sygn. 90A/c - Księga zaślubionych [2005-2006]

sygn. 90A/d - Księga zmarłych [2005-2006]

sygn. 91 - Księgi parafii pw. św. Urszuli w Lubeni

sygn. 91/a - Księga inwentarzowa

sygn. 91/b/I - Księga ochrzczonych [1971-1977]

sygn. 91/b/II - Księga ochrzczonych [1991-2000]

sygn. 91/b/III - Księga ochrzczonych [2001-2002]

sygn. 91/b/IV - Księga ochrzczonych [2003-2006]

sygn. 91/c/I - Księga zaślubionych [1971-1981]

sygn. 91/c/II - Księga zaślubionych [1982-2002]

sygn. 91/c/III - Księga zaślubionych [2003-2006]

sygn. 91/d/I - Księga zmarłych [1971-1979]

sygn. 91/d/II - Księga zmarłych [1979-2002]

sygn. 91/d/III - Księga zmarłych [2003 -2006 ]

sygn. 92 - Księgi parafii pw. św. Mikołaja w Lubli

sygn. 92/a - Księga inwentarzowa [stan z 11 II 2004roku]

sygn. 92/b - Księga ochrzczonych [1972-2003-2006]

sygn. 92/c - Księga zaślubionych [1971-2003-2006]

sygn. 92/d - Księga zmarłych [1972-2003-2006]

sygn. 92A - Księgi rektoratu pw. Matki Bożej Częstochowskiej w Lublicy

sygn. 92A/a - Księga inwentarzowa [stan z 2009roku]

sygn. 92A/b - Księga ochrzczonych [2007-2008]

sygn. 92A/c - Księga zaślubionych [2007-2008] 
sygn. 92A/d - Księga zmarłych [2007-2008]

sygn. 93 - Księgi parafii pw. Wniebowzięcia NMP w Lutczy

sygn. 93/a - Księga inwentarzowa [ksero, 2003]

sygn. 93/b - Księga ochrzczonych [1975-2003-2006]

sygn. 93/c - Księga zaślubionych [1967-2003-2006]

sygn. 93/d - Księga zmarłych [1968-2003-2006]

sygn. 94 - Księgi parafii pw. Matki Bożej Częstochowskiej i św. Józefa w Lutoryżu

sygn. 94/a - Księga inwentarzowa [brak]

sygn. 94/b - Księga ochrzczonych [1992-2002 (ksero), 2003-2006]

sygn. 94/c - Księga zaślubionych [1994-2002 (ksero), 2003-2006]

sygn. 94/d - Księga zmarłych [1994-2002 (ksero), 2003-2006]

sygn. 95 - Księgi parafii pw. św. Andrzeja Ap. i Narodzenia NMP w Łączkach

Jagiellońskich

sygn. 95/a - Księga inwentarzowa [2004]

sygn. 95/b - Księga ochrzczonych [1980-2003-2006]

sygn. 95/c - Księga zaślubionych [1980-2003-2006]

sygn. 95/d - Księga zmarłych [1980-1996, 1997-2003-2006]

sygn. 96 - Księgi parafii pw. św. Bartłomieja Ap. w Łączkach Kucharskich

sygn. 96/a - Księga inwentarzowa [stan z 2003roku]

sygn. 96/b/I - Księga ochrzczonych [1981-1986]

sygn. 96/b/II - Księga ochrzczonych [1986-1991]

sygn. 96/b/III - Księga ochrzczonych [1991-2006]

sygn. 96/c - Księga zaślubionych [1979-2002-2006]

sygn. 96/d - Księga zmarłych [1961-2002-2006]

sygn. 97 - Księgi parafii pw. św. Onufrego w Łące

sygn. 97/a - Księga inwentarzowa [stan z 2005]

sygn. 97/b - Księga ochrzczonych [1985-2006]

sygn. 97/c - Księga zaślubionych [1974-1987, 1987-1998, 1999--2006]

sygn. 97/d/ - Księga zmarłych [I - Łukawiec (1978-2001); II - Łąka (1974-1992);

III - Łąka (1993-2006)]

sygn. 98 - Księgi parafii pw. Podwyższenia Krzyża Świętego w Łękach Strzy-

żowskich

sygn. 98/a - Księga inwentarzowa

sygn. 98/b - Księga ochrzczonych [1983-1989, 1990-2002, 2003-2006]

sygn. 98/c/I - Księga zaślubionych [1983-2000]

sygn. 98/c/II - Księga zaślubionych [2001-2002, 2003-2006]

sygn. 98/d/I - Księga zmarłych [1983-1993]

sygn. 98/d/II - Księga zmarłych [1996-2002, 2003-2006]

sygn. 99 - Księgi parafii pw. św. Mikołaja w Łężynach

sygn. 99/a - Księga inwentarzowa [brak]

sygn. 99/b - Księga ochrzczonych [1973-1997, 1998-2006]

sygn. 99/c - Księga zaślubionych [1973-1998, 1999-2006]

sygn. 99/d- Księga zmarłych [1973-1998, 1999-2006]

sygn. 100 - Księgi parafii pw. św. Ignacego Antiocheńskiego i św. Maksymiliana

Kolbego w Łowisku 
sygn. 100/a - Księga inwentarzowa [2005]

sygn. 100/b - Księga ochrzczonych [1992-2006]

sygn. 100/c - Księga zaślubionych [1992-2006]

sygn. 100/d - Księga zmarłych [1992-2006]

sygn. 101 - Księgi parafii pw. Miłosierdzia Bożego w Łukawcu

sygn. 101/a - Księga inwentarzowa [stan z $19 \mathrm{~V}$ 2003roku]

sygn. 101/b - Księga ochrzczonych [1978 - 2002, 2003-2006]

sygn. 101/c - Księga zaślubionych [1978 - 2002, 2003-2006]

sygn. 101/d - Księga zmarłych [1978-2002, 2003-2006]

sygn. 102 - Księgi parafii pw. św. Piotra i św. Pawła w Łukawcu Dolnym

sygn. 102/a - Księga inwentarzowa [2001-2003]

sygn. 102/b - Księga ochrzczonych [2001-2006]

sygn. 102/c - Księga zaślubionych [2001-2006]

sygn. 102/d - Księga zmarłych [2001 -2006]

sygn. 103 - Księgi parafii pw. św. Wawrzyńca w Malawie

sygn. 103/a - Księga inwentarzowa [ksero, stan z 2003roku]

sygn. 103/b/I - Księga ochrzczonych [1983-2000]

sygn. 103/b/II - Księga ochrzczonych [2000-2002]

sygn. 103/b/III - Księga ochrzczonych [2003-2006]

sygn. 103/c/I - Księga zaślubionych [1992-2002]

sygn. 103/c/II - Księga zaślubionych [2003-2006]

sygn. 103/d/I - Księga zmarłych [1992-2002]

sygn. 103/d/II - Księga zmarłych [2003-2006]

sygn. 104 - Księgi parafii pw. św. Michała Archanioła w Małej

sygn. 104/a - Księga inwentarzowa [brak]

sygn. 104/b - Księga ochrzczonych [2000-2005]

sygn. 104/c - Księga zaślubionych [2000-2005]

sygn. 104/d - Księga zmarłych [2000-2005]

sygn. 105 - Księgi parafii pw. Wniebowzięcia NMP w Małastowie

sygn. 105/a - Księga inwentarzowa [stan z 2001roku]

sygn. 105/b - Księga ochrzczonych [1971-2006]

sygn. 105/c - Księga zaślubionych [1971-2006]

sygn. 105/d - Księga zmarłych [1971-2006]

sygn. 106 - Księgi parafii pw. Matki Bożej Królowej Polski w Matysówce

sygn. 106/a - Księga inwentarzowa [stan z 2003roku]

sygn. 106/b - Księga ochrzczonych [1981-1996 (ksero), 1997-2002; 2003-2006]

sygn. 106/c - Księga zaślubionych [1981-1996 (ksero), 1997-2002; 2003-2006]

sygn. 106/d - Księga zmarłych [1981-1996 (ksero), 1997-2002; 2003-2006]

sygn. 106/e - Księga bierzmowanych [1981-1992 (ksero)]

sygn. 107 - Księgi parafii pw. Matki Bożej Nieustającej Pomocy w Mazurach

sygn. 107/a - Księga inwentarzowa [jest, ksero]

sygn. 107/b - Księga ochrzczonych [Korczowiska 1959-2002 (ksero), Mazury 1975-2002 (ksero); 2003-2006]

sygn. 107/c - Księga zaślubionych [1979-2002, 2003-2006]

sygn. 107/d - Księga zmarłych [1980-2002, 2003-2006] 
sygn. 108 - Księgi parafii pw. Nawiedzenia NMP w Medyni Głogowskiej

sygn. 108/a - Księga inwentarzowa [stan z 11 XII 2004]

sygn. 108/b/I - Księga ochrzczonych [1979 - 1992]

sygn. 108/b/II - Księga ochrzczonych [1992 - 2002]

sygn. 108/b/III - Księga ochrzczonych [2003-2006]

sygn. 108/c/I - Księga zaślubionych [1981- 2002]

sygn. 108/c/II - Księga zaślubionych [2003-2006]

sygn. 108/d/I - Księga zmarłych [1981-2002]

sygn. 108/d/II - Księga zmarłych [2003-2006]

sygn. 109 - Księgi parafii pw. św. Kosmy i św. Damiana w Męcinie Wielkiej

sygn. 109/a - Księga inwentarzowa [2003]

sygn. 109/b - Księga ochrzczonych [1992-2006]

sygn. 109/c - Księga zaślubionych [1992-2006]

sygn. 109/d - Księga zmarłych [1992-2006]

sygn. 110 - Księgi parafii pw. św. Huberta w Miłocinie

sygn. 110/a - Księga inwentarzowa

sygn. 110/b/I - Księga ochrzczonych [1969-2002]

sygn. 110/b/II - Księga ochrzczonych [2003-2006]

sygn. 110/c/I - Księga zaślubionych [1969-2002]

sygn. 110/c/II - Księga zaślubionych [2003-2006]

sygn. 110/d/I - Księga zmarłych [1971-2002]

sygn. 110/d/II - Księga zmarłych [2003-2006]

sygn. 111 - Księgi parafii pw. Podwyższenia Krzyża Świętego i NMP Matki Kościoła w Mogielnicy

sygn. 111/a - Księga inwentarzowa [2003]

sygn. 111/b - Księga ochrzczonych [1951-2003-2006]

sygn. 111/c - Księga zaślubionych [1982-2003-2006]

sygn. 111/d - Księga zmarłych [1982-2003-2006]

sygn. 112 - Księgi parafii pw. św. Łukasza Ewangelisty w Mrowli

sygn. 112/a - Księga inwentarzowa [ksero, 2003]

sygn. 112/b/I - Księga ochrzczonych [1975-1981]

sygn. 112/b/II - Księga ochrzczonych [1982- 2002]

sygn. 112/b/III - Księga ochrzczonych [2003-2006]

sygn. 112/c/I - Księga zaślubionych [1975-1991]

sygn. 112/c/II - Księga zaślubionych [1992-2002]

sygn. 112/c/III - Księga zaślubionych [2003-2006]

sygn. 112/d/I - Księga zmarłych [1975-1989]

sygn. 112/d/II - Księga zmarłych [1989-2002]

sygn. 112/d/III - Księga zmarłych [2003-2006]

sygn. 113 - Księgi parafii pw. św. Andrzeja Boboli w Nawsiu

sygn. 113/a - Księga inwentarzowa [2002]

sygn. 113/b - Księga ochrzczonych [1983-2002, 2003-2006]

sygn. 113/c - Księga zaślubionych [1983-2002, 2003-2006]

sygn. 113/d - Księga zmarłych [1983-2002, 2003-2006]

sygn. 114 - Księgi parafii pw. Znalezienia Krzyża Świętego w Niebylcu 
sygn. 114/a - Księga inwentarzowa [2003]

sygn. 114/b - Księga ochrzczonych [1976-2006]

sygn. 114/c - Księga zaślubionych [1976-2006]

sygn. 114/d - Księga zmarłych [1976-2006]

sygn. 115 - Księgi parafii pw. Matki Bożej Nieustającej Pomocy w Niechobrzu

sygn. 115/a - Księga inwentarzowa [brak]

sygn. 115/b/I - Księga ochrzczonych [1971- 1987]

sygn. 115/b/II - Księga ochrzczonych [1988-1996]

sygn. 115/b/III - Księga ochrzczonych [1997-2002]

sygn. 115/b/IV - Księga ochrzczonych [2003-2006]

sygn. 115/c - Księga zaślubionych [1968-1983, 1984-2002, 2003-2006]

sygn. 115/d - Księga zmarłych [1970-1986, 1987-2002, 2003-2006]

sygn. 116 - Księgi parafii pw. Chrystusa Króla w Niedźwiadzie

sygn. 116/a - Księga inwentarzowa [brak]

sygn. 116/b - Księga ochrzczonych [1991-2006]

sygn. 116/c - Księga zaślubionych [1991-2006]

sygn. 116/d - Księga zmarłych [1991-2006]

sygn. 117 - Księgi parafii pw. św. Bartłomieja Ap. w Nienadówce

sygn. 117/a - Księga inwentarzowa [brak]

sygn. 117/b/I - Księga ochrzczonych [1979-1980]

sygn. 117/b/II - Księga ochrzczonych [1981-1998]

sygn. 117/b/III - Księga ochrzczonych [1999-2006]

sygn. 117/c/I - Księga zaślubionych [brak]

sygn. 117/c/II - Księga zaślubionych [1995-2006]

sygn. 117/d/I - Księga zmarłych [brak]

sygn. 117/d/II - Księga zmarłych [1995-2006]

sygn. 118 - Księgi parafii pw. Wniebowzięcia NMP w Nienaszowie

sygn. 118/a - Księga inwentarzowa [ksero, 2002]

sygn. 118/b - Księga ochrzczonych [1986-1995, 1995-2006]

sygn. 118/c - Księga zaślubionych [1973-1997, 1998-2006]

sygn. 118/d - Księga zmarłych [1973-2001, 2002-2006]

sygn. 119 - Księgi parafii pw. św. Anny w Niewodnej

sygn. 119/a - Księga inwentarzowa [2005]

sygn. 119/b/I - Księga ochrzczonych [1972-2002]

sygn. 119/b/II - Księga ochrzczonych [2003-2006]

sygn. 119/c/I - Księga zaślubionych [1972-2002]

sygn. 119/c/II - Księga zaślubionych [2003-2006]

sygn. 119/d/I - Księga zmarłych [1960-2002]

sygn. 119/d/II - Księga zmarłych [2003-2006]

sygn. 120 - Księgi parafii pw. św. Mikołaja w Niwiskach

sygn. 120/a - Księga inwentarzowa [stan z 1 III 2004]

sygn. 120/b/I - Księga ochrzczonych [1959-1985]

sygn. 120/b/II - Księga ochrzczonych [1986-2003 (ksero), 2004-2006]

sygn. 120/c - Księga zaślubionych [1986-2003 (ksero), 2004-2006]

sygn. 120/d - Księga zmarłych [1986-2003 (ksero), 2004-2006] 
sygn. 121 - Księgi parafii pw. św. Michała Archanioła w Nockowej

sygn. 121/a - Księga inwentarzowa [stan z 2004roku]

sygn. 121/b/I - Księga ochrzczonych [1992-2002]

sygn. 121/b/II - Księga ochrzczonych [2003-2006]

sygn. 121/c/I - Księga zaślubionych [1992-2002]

sygn. 121/c/II - Księga zaślubionych [2003-2006]

sygn. 121/d/I - Księga zmarłych [1992-2002]

sygn. 121/d/II - Księga zmarłych [2003-2006]

sygn. 122 - Księgi parafii pw. Zwiastowania NMP w Nowej Wsi Czudeckiej

sygn. 122/a - Księga inwentarzowa

sygn. 122/b - Księga ochrzczonych [1988-2002, 2003-2006]

sygn. 122/c - Księga zaślubionych [1989-2002 (ksero), 2003-2006]

sygn. 122/d - Księga zmarłych [1989-2002 (ksero), 2003-2006]

sygn. 123 - Księgi parafii pw. Dobrego Pasterza w Nowej Wsi Zaczerskiej

sygn. 123/a - Księga inwentarzowa [2003]

sygn. 123/b - Księga ochrzczonych [1988-1997, 1998-2006]

sygn. 123/c - Księga zaślubionych [1988-2006]

sygn. 123/d - Księga zmarłych [1988-2006]

sygn. 124 - Księgi parafii pw. świętych Apostołów Piotra i Pawła w Nowym

Żmigrodzie

sygn. 124/a - Księga inwentarzowa [stan z 2004roku]

sygn. 124/b/I - Księga ochrzczonych [1998-2002]

sygn. 124/b/II- Księga ochrzczonych [2003-2006]

sygn. 124/c/I - Księga zaślubionych [1982-2002]

sygn. 124/c/II - Księga zaślubionych [2003-2006]

sygn. 124/d/I - Księga zmarłych [1979-2002]

sygn. 124/d/II - Księga zmarłych [2003-2006]

sygn. 125 - Księgi parafii pw. Matki Bożej Fatimskiej w Olchowej

sygn. 125/a - Księga inwentarzowa [ksero]

sygn. 125/b - Księga ochrzczonych [1987-2006]

sygn. 125/c - Księga zaślubionych [1995-2006]

sygn. 125/d - Księga zmarłych [1994-2006]

sygn. 126 - Księgi parafii pw. Przemienienia Pańskiego w Osieku Jasielskim

sygn. 126/a - Księga inwentarzowa

sygn. 126/b - Księga ochrzczonych [1973-2002, 2003-2006]

sygn. 126/c - Księga zaślubionych [1977-2003-2006]

sygn. 126/d - Księga zmarłych [1977-2003-2006]

sygn. 127 - Księgi parafii pw. św. Stanisława Biskupa w Osobnicy

sygn. 127/a - Księga inwentarzowa [ksero, stan z 2004roku]

sygn. 127/b - Księga ochrzczonych [1992-2002, 2003-2006]

sygn. 127/c - Księga zaślubionych [1986-2002, 2003-2006]

sygn. 127/d - Księga zmarłych [1992-2002, 2003-2006]

sygn. 128 - Księgi parafii pw. Wniebowzięcia NMP w Ostrowach Tuszowskich

sygn. 128/a - Księga inwentarzowa

sygn. 128/b - Księga ochrzczonych [1987-2002 (ksero), 2003-2006] 
sygn. 128/c - Księga zaślubionych [1987-2002 (ksero), 2003-2006]

sygn. 128/d - Księga zmarłych [1987-2002 (ksero), 2003-2006]

sygn. 129 - Księgi parafii pw. Najświętszego Serca Pana Jezusa w Pagorzynie

sygn. 129/a - Księga inwentarzowa [2003]

sygn. 129/b - Księga ochrzczonych [1992-2006]

sygn. 129/c - Księga zaślubionych [1993-2003 (ksero), 2004-2006]

sygn. 129/d - Księga zmarłych [1994-2003 (ksero), 2004-2006]

sygn. 130 - Księgi parafii pw. Miłosierdzia Bożego w Palikówce

sygn. 130/a - Księga inwentarzowa [2002]

sygn. 130/b - Księga ochrzczonych [2000-2003 (ksero), 2004-2006]

sygn. 130/c - Księga zaślubionych [2000-2003 (ksero), 2004-2006]

sygn. 130/d - Księga zmarłych [2000-2003 (ksero), 2004-2006]

sygn. 131 - Księgi parafii pw. Matki Bożej Częstochowskiej w Polanach

sygn. 131/a - Księga inwentarzowa [stan z 2003roku]

sygn. 131/b - Księga ochrzczonych [1969-1999, 2000-2006]

sygn. 131/c - Księga zaślubionych [1969-2003, 2004-2006]

sygn. 131/d - Księga zmarłych [1970-2003, 2004-2006]

sygn. 132 - Księgi parafii pw. św. Mikołaja w Połomii

sygn. 132/a - Księga inwentarzowa [ksero]

sygn. 132/b - Księga ochrzczonych [1990-2002 (ksero), 2003-2006]

sygn. 132/c - Księga zaślubionych [1990-2002 (ksero), 2003-2006]

sygn. 132/d - Księga zmarłych [1990-2002 (ksero), 2003-2006]

sygn. 133 - Księgi parafii pw. św. Stanisława i św. Wojciecha w Porębach Dymarskich

sygn. 133/a - Księga inwentarzowa [ksero, 2003]

sygn. 133/b - Księga ochrzczonych [1992-2006]

sygn. 133/c - Księga zaślubionych [1992-2006]

sygn. 133/d - Księga zmarłych [1992-2006]

sygn. 134 - Księgi parafii pw. św. Józefa Rzemieślnika w Przedborzu

sygn. 134/a - Księga inwentarzowa [ksero]

sygn. 134/b - Księga ochrzczonych [1992-2002 (ksero), 2003-2006]

sygn. 134/c - Księga zaślubionych [1992-2002 (ksero), 2003-2006]

sygn. 134/d - Księga zmarłych [1992-2002 (ksero), 2003-2006]

sygn. 135 - Księgi parafii pw. św. Antoniego Padewskiego w Przewrotnem

sygn. 135/a - Księga inwentarzowa [2006]

sygn. 135/b/I - Księga ochrzczonych [1992-2002 (ksero), 2003-2006]

sygn. 135/b/II - Księga ochrzczonych (Hucisko) [1977-1992, 1991-2002 (ksero), 2003-2006]

sygn. 135/b/III - Księga ochrzczonych (Pogwizdów St.) [1977-1992, 1991-2002

(ksero), 2003-2006]

sygn. 135/c - Księga zaślubionych [1997-1992, 1994-1998, 1999-2002 (ksero), 2003-2006]

sygn. 135/d - Księga zmarłych [1977-1992, 1994-1998, 1999-2002 (ksero), 20032006]

sygn. 136 - Księgi parafii pw. św. Kazimierza w Przybówce 
sygn. 136/a - Księga inwentarzowa [ksero]

sygn. 136/b - Księga ochrzczonych [2000-2006]

sygn. 136/c - Księga zaślubionych [2000-2002 (ksero), 2003-2006]

sygn. 136/d - Księga zmarłych [2000-2006]

sygn. 137 - Księgi parafii pw. św. Józefa Robotnika w Pstrągowej

sygn. 137/a - Księga inwentarzowa [2003]

sygn. 137/b - Księga ochrzczonych [1992-2006]

sygn. 137/c - Księga zaślubionych [1992-2006]

sygn. 137/d - Księga zmarłych [1992-2006]

sygn. 138 - Księgi parafii pw. św. Jana Chrzciciela w Pstrągówce

sygn. 138/a - Księga inwentarzowa [1993, 2003]

sygn. 138/b - Księga ochrzczonych [1976-1995, 1995-2006]

sygn. 138/c - Księga zaślubionych [1979-2002, 2003-2006]

sygn. 138/d - Księga zmarłych [1978-2002, 2003-2006]

sygn. 139 - Księgi parafii pw. św. Maksymiliana Kolbego w Rogoźnicy

sygn. 139/a - Księga inwentarzowa [brak]

sygn. 139/b - Księga ochrzczonych [1995-2002 (ksero), 2003-2006]

sygn. 139/c - Księga zaślubionych [1995-2002 (ksero), 2003-2006]

sygn. 139/d - Księga zmarłych [1995-2002 (ksero), 2003-2006]

sygn. 140 - Księgi parafii pw. Przemienienia Pańskiego w Ropczycach

sygn. 140/a - Księga inwentarzowa [ksero, 2003]

sygn. 140/b/I - Księga ochrzczonych [1972-1991]

sygn. 140/b/II - Księga ochrzczonych [1992-2000]

sygn. 140/b/III - Księga ochrzczonych [2001-2002]

sygn. 140/b/IV - Księga ochrzczonych [2003-2006]

sygn. 140/c/I - Księga zaślubionych [1972-1999]

sygn. 140/c/II - Księga zaślubionych [1999 - 2002]

sygn. 140/c/III - Księga zaślubionych [2003-2006]

sygn. 140/d/I - Księga zmarłych [1972-2002]

sygn. 140/d/II - Księga zmarłych [2003-2006]

sygn. 141 - Księgi parafii pw. św. Urszuli Ledóchowskiej w Ropczycach

sygn. 141/a - Księga inwentarzowa [2002]

sygn. 141/b/I - Księga ochrzczonych [1999-2002]

sygn. 141/b/II - Księga ochrzczonych [2003-2006]

sygn. 141/c/I - Księga zaślubionych [1999-2002]

sygn. 141/c/II - Księga zaślubionych [2003-2006]

sygn. 141/d/I - Księga zmarłych [1999-2002]

sygn. 141/d/II - Księga zmarlych [2003-2006]

sygn. 142 - Księgi parafii pw. Świętej Rodziny w Ropczycach (Czekaj)

sygn. 142/a - Księga inwentarzowa [2006]

sygn. 142/b/I- Księga ochrzczonych [1984-2002]

sygn. 142/b/II- Księga ochrzczonych [2003-2006]

sygn. 142/c/I- Księga zaślubionych [1984-2002]

sygn. 142/c/II - Księga zaślubionych [2003-2006]

sygn. 142/d/I - Księga zmarłych [1984-2002] 
sygn. 142/d/II - Księga zmarłych [2003-2006]

sygn. 143 - Księgi parafii pw. św. Barbary w Ropczycach

sygn. 143/a - Księga inwentarzowa [2006]

sygn. 143/b - Księga ochrzczonych [1999-2006]

sygn. 143/c - Księga zaślubionych [1999-2006]

sygn. 143/d - Księga zmarłych [1999-2006]

sygn. 144 - Księgi parafii pw. św. Anny w Ropczycach (Chechły)

sygn. 144/a - Księga inwentarzowa [ksero]

sygn. 144/b/I - Księga ochrzczonych [1976-1991]

sygn. 144/b/II - Księga ochrzczonych [1991-2003-2006]

sygn. 144/c - Księga zaślubionych [1976-2003-2006]

sygn. 144/d - Księga zmarłych [1976-2003-2006]

sygn. 145 - Księgi parafii pw. św. Michała Archanioła w Ropczycach (Witkowice)

sygn. 145/a - Księga inwentarzowa [stan z roku 2003]

sygn. 145/b/I - Księga ochrzczonych [1986-1991]

sygn. 145/b/II - Księga ochrzczonych [1991 - 2002]

sygn. 145/b/III - Księga ochrzczonych [2003-2006]

sygn. 145/c/I - Księga zaślubionych [1984-2002]

sygn. 145/c/II - Księga zaślubionych [2003-2006]

sygn. 145/d/I - Księga zmarłych [1980-2002]

sygn. 145/d/II - Księga zmarłych [2003-2006]

sygn. 146 - Księgi parafii pw. Miłosierdzia Bożego w Ropicy Polskiej

sygn. 146/a - Księga inwentarzowa [brak]

sygn. 146/b - Księga ochrzczonych [1992-2006]

sygn. 146/c - Księga zaślubionych [1992-2006]

sygn. 146/d - Księga zmarłych [1992-2006]

sygn. 147 - Księgi parafii pw. św. Andrzeja Apostoła w Rożnowicach

sygn. 147/a - Księga inwentarzowa [2007]

sygn. 147/b - Księga ochrzczonych [1992-2006]

sygn. 147/c - Księga zaślubionych [1992-2006]

sygn. 147/d - Księga zmarłych [1992-2006]

sygn. 148 - Księgi parafii pw. św. Teresy od Dzieciątka Jezus w Rudnej Wielkiej

sygn. 148/a - Księga inwentarzowa [2003]

sygn. 148/b/I - Księga ochrzczonych (Rudna Mała) [1976-1982]

sygn. 148/b/II - Księga ochrzczonych (Rogoźnica, Pogwizdów Nowy, Rudna Mała) [1976-1981]

sygn. 148/b/III - Księga ochrzczonych [1977-1982]

sygn. 148/b/IV - Księga ochrzczonych [1982-2000]

sygn. 148/b/V - Księga ochrzczonych [2001-2002]

sygn. 148/b/VI - Księga ochrzczonych [2003-2006]

sygn. 148/c/I - Księga zaślubionych [1966-1982]

sygn. 148/c/II - Księga zaślubionych [1982-1992]

sygn. 148/c/III - Księga zaślubionych [1993-1999]

sygn. 148/c/IV - Księga zaślubionych [2000-2002]

sygn. 148/c/V - Księga zaślubionych [2003-2006] 
sygn. 148/d/I - Księga zmarłych [1976-1982]

sygn. 148/d/II - Księga zmarłych [1982-1992]

sygn. 148/d/III - Księga zmarłych [1993-1998]

sygn. 148/d/IV- Księga zmarłych [1999-2002]

sygn. 148/d/V - Księga zmarłych [2003-2006]

sygn. 149 - Księgi parafii pw. Bożego Ciała i Matki Bożej w Lourdes w Rzeszowie

sygn. 149/a - Księga inwentarzowa [ksero, stan z 2002roku]

sygn. 149/b/I - Księga ochrzczonych [1988-1996]

sygn. 149/b/II - Księga ochrzczonych [1996-2006]

sygn. 149/c - Księga zaślubionych [1980-2006]

sygn. 149/d - Księga zmarłych [1981-2006]

sygn. 150 - Księgi parafii pw. bł. Karoliny Kózka w Rzeszowie

sygn. 150/a - Księga inwentarzowa [brak]

sygn. 150/b - Księga ochrzczonych [1999-2006]

sygn. 150/c - Księga zaślubionych [1999-2006]

sygn. 150/d - Księga zmarłych [1999-2006]

sygn. 151 - Księgi parafii pw. Chrystusa Króla w Rzeszowie

sygn. 151/a - Księga inwentarzowa [ksero]

sygn. 151/b - Księga ochrzczonych [1992-2002 (ksero), 2003-2006]

sygn. 151/c - Księga zaślubionych [1992-2002 (ksero), 2003-2006]

sygn. 151/d - Księga zmarłych [1992-2002 (ksero), 2003-2006]

sygn. 152 - Księgi parafii pw. Matki Bożej Królowej Polski w Rzeszowie (Garnizonowy)

sygn. 152/a - Księga inwentarzowa [ksero, 2003]

sygn. 152/b - Księga ochrzczonych [1993-2002; 2003 (ksero), 2004-2006]

sygn. 152/c - Księga zaślubionych [2000-2002; 2003 (ksero), 2004-2006]

sygn. 152/d - Księga zmarlych [1969-2002; 2003 (ksero), 2004-2006]

sygn. 153 - Księgi parafii pw. Matki Bożej Różańcowej w Rzeszowie

sygn. 153/a - Księga inwentarzowa [brak]

sygn. 153/b/I - Księga ochrzczonych [1986-1991]

sygn. 153/b/II - Księga ochrzczonych [1991-1994]

sygn. 153/b/III - Księga ochrzczonych [1995-2006]

sygn. 153/c - Księga zaślubionych [1983-2001, 2002 - 2006]

sygn. 153/d - Księga zmarłych [1976-1994, 1992-2007]

sygn. 154 - Księgi parafii pw. Matki Bożej Saletyńskiej w Rzeszowie (Saletyni)

sygn. 154/a - Księga inwentarzowa [brak]

sygn. 154/b/I - Księga ochrzczonych [1987-1989]

sygn. 154/b/II - Księga ochrzczonych [1990-1995]

sygn. 154/b/III - Księga ochrzczonych [1995-1998]

sygn. 154/b/IV - Księga ochrzczonych [1998-2000]

sygn. 154/b/V - Księga ochrzczonych [2001-2002]

sygn. 154/b/VI - Księga ochrzczonych [2003-2006]

sygn. 154/c/I - Księga zaślubionych [1985-1995]

sygn. 154/c/II - Księga zaślubionych [1996-2002]

sygn. 154/c/III - Księga zaślubionych [2003-2006] 
sygn. 154/d/I - Księga zmarłych [1987-1993]

sygn. 154/d/II - Księga zmarłych [1993-2002]

sygn. 154/d/III - Księga zmarłych [2003-2006]

sygn. 154A - Księgi parafii pw. Matki Bożej Częstochowskiej w Rzeszowie (Dra-

binianka)

sygn. 154A/a - Księga inwentarzowa

sygn. $154 \mathrm{~A} / \mathrm{b}-$ Księga ochrzczonych

sygn. 154A/c - Księga zaślubionych

sygn. $154 \mathrm{~A} / \mathrm{d}$ - Księga zmarłych

sygn. 155 - Księgi parafii pw. Najświętszego Serca Pana Jezusa w Rzeszowie (Katedra)

sygn. 155/a - Księga inwentarzowa [stan z 2003roku]

sygn. 155/b/I - Księga ochrzczonych [1984-1987]

sygn. 155/b/II - Księga ochrzczonych [1987-1993]

sygn. 155/b/III - Księga ochrzczonych [1994-1997]

sygn. 155/b/IV - Księga ochrzczonych [1997-2002, 2003-2006]

sygn. 155/c/I - Księga zaślubionych [1973-1984]

sygn. 155/c/II - Księga zaślubionych [1984-1995]

sygn. 155/c/III - Księga zaślubionych [1996-2002, 2003-2006]

sygn. 155/d/I - Księga zmarłych [1983-1994]

sygn. 155/d/II - Księga zmarlych [1994-2002, 2003-2006]

sygn. 156 - Księgi parafii pw. Narodzenia NMP w Rzeszowie (Staroniwa)

sygn. 156/a - Księga inwentarzowa [ksero]

sygn. 156/b - Księga ochrzczonych [1975-1984, 1984-1990, 1990 - 2003-2006]

sygn. 156/c - Księga zaślubionych [1975-2003-2006]

sygn. 156/d - Księga zmarłych [1975-2000, 2001-2003-2006]

sygn. 157 - Księgi parafii pw. Opatrzności Bożej w Rzeszowie (Salezjanie)

sygn. 157/a - Księga inwentarzowa [ksero]

sygn. 157/b/I - Księga ochrzczonych [1985-1987]

sygn. 157/b/II - Księga ochrzczonych [1987-1992]

sygn. 157/b/III - Księga ochrzczonych [1992-1999 (część ksero)]

sygn. 157/b/IV - Księga ochrzczonych [2000-2006]

sygn. 157/c - Księga zaślubionych [1986 -2006]

sygn. 157/d/I - Księga zmarłych [1985-1994]

sygn. 157/d/II - Księga zmarłych [1995-2002]

sygn. 157/d/III - Księga zmarłych [2003-2006]

sygn. 158 - Księgi parafii pw. Podwyższenia Krzyża Świętego w Rzeszowie

sygn. 158/a - Księga inwentarzowa [ksero]

sygn. 158/b/I - Księga ochrzczonych [1986-1987]

sygn. 158/b/II - Księga ochrzczonych [1988-1997; 1998-2003]

sygn. 158/b/III - Księga ochrzczonych [2004-2007]

sygn. 158/c/I - Księga zaślubionych [1986-1994]

sygn. 158/c/II - Księga zaślubionych [1995-1999; 2000-2007]

sygn. 158/d/I - Księga zmarłych [1979-1993]

sygn. 158/d/II - Księga zmarłych [1994-1997; 1998-2002; 2003-2007] 
sygn. 159 - Księgi parafii pw. św. Jacka w Rzeszowie (Dominikanie)

sygn. 159/a - Księga inwentarzowa [nie ma]

sygn. 159/b/I - Księga ochrzczonych [1990-1996]

sygn. 159/b/II - Księga ochrzczonych [1997-2002, 2003-2005]

sygn. 159/c - Księga zaślubionych [1990-2002, 2003-2005]

sygn. 159/d - Księga zmarłych [1990-2002, 2003-2005]

sygn. 160 - Księgi parafii pw. św. Jadwigi Królowej w Rzeszowie

sygn. 160/a - Księga inwentarzowa [stan z 2004roku]

sygn. 160/b - Księga ochrzczonych [2004]

sygn. 160/c - Księga zaślubionych

sygn. 160/d - Księga zmarłych

sygn. 161 - Księgi parafii pw. św. Józefa w Rzeszowie (Staromieście)

sygn. 161/a - Księga inwentarzowa [stan z roku 2003]

sygn. 161/b - Księga ochrzczonych [1992-2002, 2003-2006]

sygn. 161/c/I - Księga zaślubionych [1990-1998]

sygn. 161/c/II - Księga zaślubionych [1999 - 2002, 2003-2006]

sygn. 161/d/I - Księga zmarłych [1992-2000]

sygn. 161/d/II - Księga zmarłych [2000- 2002, 2003-2006]

sygn. 162 - Księgi parafii pw. św. Józefa w Rzeszowie - Zwięczycy

sygn. 162/a - Księga inwentarzowa [2007]

sygn. 162/b/I - Księga ochrzczonych [1988-1999]

sygn. 162/b/II - Księga ochrzczonych [2000-2003 (ksero), 2003-2006]

sygn. 162/c/I - Księga zaślubionych [1984-2002]

sygn. 162/c/II - Księga zaślubionych [2003-2006]

sygn. 162/d/I - Księga zmarłych [1985-2000]

sygn. 162/d/II - Księga zmarłych [2000-2006]

sygn. 163 - Księgi parafii pw. św. Józefa Kalasancjusza w Rzeszowie (Pijarzy)

sygn. 163/a - Księga inwentarzowa [brak]

sygn. 163/b/I - Księga ochrzczonych [1975-1991]

sygn. 163/b/II - Księga ochrzczonych [1992-1999]

sygn. 163/b/III - Księga ochrzczonych [1999-2003]

sygn. 163/b/IV - Księga ochrzczonych [2004-2006]

sygn. 163/c/I - Księga zaślubionych [1975-2003]

sygn. 163/c/II - Księga zaślubionych [2004-2006]

sygn. 163/d/I - Księga zmarłych [1975-2003]

sygn. 163/d/II - Księga zmarłych [2004-2006]

sygn. 164 - Księgi parafii pw. św. Józefa Sebastiana Pelczara w Rzeszowie

sygn. 164/a - Księga inwentarzowa [stan z 1997, uzup. 2002]

sygn. 164/b - Księga ochrzczonych [1995-2006]

sygn. 164/c - Księga zaślubionych [1995-2006]

sygn. 164/d - Księga zmarłych [1995-2006]

sygn. 165 - Księgi parafii pw. św. Judy Tadeusza w Rzeszowie

sygn. 165/a - Księga inwentarzowa [ksero, stan z 2003roku]

sygn. 165/b/I - Księga ochrzczonych [1988-1989]

sygn. 165/b/II - Księga ochrzczonych [1990-1991] 
sygn. 165/b/III - Księga ochrzczonych [1992-1994]

sygn. 165/b/IV - Księga ochrzczonych [1994-2002]

sygn. 165/b/V - Księga ochrzczonych [2003-2006]

sygn. 165/c/I - Księga zaślubionych [1979-1991]

sygn. 165/c/II - Księga zaślubionych [1992-2002, 2003-2006]

sygn. 165/d - Księga zmarłych [1979-2002, 2003-2006]

sygn. 166 - Księgi parafii pw. Świętego Krzyża w Rzeszowie

sygn. 166/a - Księga inwentarzowa [jest, ksero]

sygn. 166/b - Księga ochrzczonych [1986-2002 (ksero), 2003-2006]

sygn. 166/c - Księga zaślubionych [1987-1994 (ksero), 1994-2002, 2003-2006]

sygn. 166/d/I - Księga zmarłych [1970-1995 (ksero)]

sygn. 166/d/II - Księga zmarłych [1995-2002 (ksero)]

sygn. 166/d/III - Księga zmarłych [2003-2006]

sygn. 167 - Księgi parafii pw. św. Michała Archanioła w Rzeszowie

sygn. 167/a - Księga inwentarzowa [brak]

sygn. 167/b/I - Księga ochrzczonych [1981-1984]

sygn. 167/b/II - Księga ochrzczonych [1984-1988]

sygn. 167/b/III - Księga ochrzczonych [1989-1990]

sygn. 167/b/IV - Księga ochrzczonych [1990-1993]

sygn. 167/b/V - Księga ochrzczonych [1993-1995]

sygn. 167/b/VI - Księga ochrzczonych [1995-1999]

sygn. 167/b/VII - Księga ochrzczonych [2000-2006]

sygn. 167/c/I - Księga zaślubionych [1981-2002]

sygn. 167/c/II - Księga zaślubionych [2003-2006]

sygn. 167/d/I - Księga zmarłych [1981-2002]

sygn. 167/d/II - Księga zmarłych [2003-2006]

sygn. 168 - Księgi parafii pw. św. Mikołaja w Rzeszowie - Przybyszówce

sygn. 168/a - Księga inwentarzowa [2007]

sygn. 168/b/I - Księga ochrzczonych [1984-1988]

sygn. 168/b/II - Księga ochrzczonych [1989-1992]

sygn. 168/b/III - Księga ochrzczonych [1993-2002]

sygn. 168/b/IV - Księga ochrzczonych [2003-2006]

sygn. 168/c/I - Księga zaślubionych [1984-1992]

sygn. 168/c/II - Księga zaślubionych [1993-2002]

sygn. 168/c/III - Księga zaślubionych [2003-2006]

sygn. 168/d/I - Księga zmarłych [1984-1992]

sygn. 168/d/II - Księga zmarłych [1993-2002]

sygn. 168/d/III - Księga zmarłych [2003-2006]

sygn. 169 - Księgi parafii pw. św. Rocha w Rzeszowie - Słocinie

sygn. 169/a - Księga inwentarzowa [ksero]

sygn. 169/b - Księga ochrzczonych [(1992-2002) ksero, 2003]

sygn. 169/c - Księga zaślubionych [ (1992-2002) ksero, 2003]

sygn. 169/d - Księga zmarłych [(1992-2002) ksero, 2003]

sygn. 170 - Księgi parafii pw. Świętej Rodziny w Rzeszowie (Misjonarze Św. Rodziny) 
sygn. 170/a - Księga inwentarzowa [ksero]

sygn. 170/b/I - Księga ochrzczonych [1985-1988]

sygn. 170/b/II - Księga ochrzczonych [1988-1994]

sygn. 170/b/III - Księga ochrzczonych [1995-2002]

sygn. 170/b/IV - Księga ochrzczonych [2003-2006]

sygn. 170/c/I - Księga zaślubionych [1986-2002]

sygn. 170/c/II - Księga zaślubionych [2003-2006]

sygn. 170/d/I - Księga zmarłych [1986-2002]

sygn. 170/d/II - Księga zmarłych [2003-2006]

sygn. 170/e - Spisy osób bierzmowanych [2004-2005]

sygn. 171 - Księgi Rektoratu pw. Świętej Trójcy w Rzeszowie

sygn. 171/a - Księga inwentarzowa [jest]

sygn. 172 - Księgi parafii pw. św. Wojciecha i św. Stanisława w Rzeszowie (Fara)

sygn. 172/a - Księga inwentarzowa [stan z 1997roku]

sygn. 172/b/I - Księga ochrzczonych [1987-1993]

sygn. 172/b/II - Księga ochrzczonych [1993-2002]

sygn. 172/b/III - Księga ochrzczonych [2003-2006]

sygn. 172/c - Księga zaślubionych [1992-2006]

sygn. 172/d/I - Księga zmarłych [1991-2000]

sygn. 172/d/II - Księga zmarłych [2001-2006]

sygn. 173 - Księgi parafii pw. Wniebowzięcia NMP w Rzeszowie (Bernardyni)

sygn. 173/a - Księga inwentarzowa [brak]

sygn. 173/b/I - Księga ochrzczonych [1984-1991]

sygn. 173/b/II - Księga ochrzczonych [1992-2002]

sygn. 173/b/III - Księga ochrzczonych [2003-2006]

sygn. 173/c/I - Księga zaślubionych [1976-1995]

sygn. 173/c/II - Księga zaślubionych [1996-2002]

sygn. 173/c/III - Księga zaślubionych [2003-2006]

sygn. 173/d/I - Księga zmarłych [1976-1995]

sygn. 173/d/II - Księga zmarłych [1996-2002]

sygn. 173/d/III - Księga zmarłych [2003-2006]

sygn. 174 - Księgi parafii pw. Wniebowzięcia NMP w Rzeszowie- Zalesiu

sygn. 174/a - Księga inwentarzowa [ksero]

sygn. 174/b/I - Księga ochrzczonych [1975 - 1985]

sygn. 174/b/II - Księga ochrzczonych [1986-1991]

sygn. 174/b/III - Księga ochrzczonych [1992-2002]

sygn. 174/b/IV - Księga ochrzczonych [2003-2006]

sygn. 174/c/I - Księga zaślubionych [1977-2002]

sygn. 174/c/II - Księga zaślubionych [2003-2006]

sygn. 174/d/I - Księga zmarłych [1980-2002]

sygn. 174/d/II - Księga zmarłych [2003-2006]

sygn. 175 - Księgi parafii pw. św. Marii Magdaleny w Samoklęskach

sygn. 175/a - Księga inwentarzowa

sygn. 175/b - Księga ochrzczonych [1982-1986, 1987-1993, 1994-2006]

sygn. 175/c - Księga zaślubionych [1973-1984, 1985-1996, 1997-2006] 
sygn. 175/d - Księga zmarłych [1973-1986, 1987-1996, 1997-2006] sygn. 176 - Księgi parafii pw. Narodzenia NMP w Sędziszowie Małopolskim sygn. 176/a - Księga inwentarzowa sygn. 176/b/I - Księga ochrzczonych [Sędziszów (1987-1991), Sielec (1987-1992)] sygn. 176/b/II - Księga ochrzczonych [Sędziszów (1992-2000)] sygn. 176/b/III - Księga ochrzczonych [Sielec (1993-2000)] sygn. 176/b/IV - Księga ochrzczonych [Wolica Ługowa (1987-2000)] sygn. 176/b/V - Księga ochrzczonych [Wolica Piaskowa (1987-2000)] sygn. 176/b/VI - Księga ochrzczonych [2001-2002] sygn. 176/b/VII - Księga ochrzczonych [2003-2006] sygn. 176/c/I - Księga zaślubionych [1987-1992] sygn. 176/c/II - Księga zaślubionych [Sędziszów (1993-2000)] sygn. 176/c/III - Księga zaślubionych [Sielec (1996-2000)] sygn. 176/c/IV - Księga zaślubionych [Wolica Ługowa (1994-2000)] sygn. 176/c/V - Księga zaślubionych [Wolica Piaskowa (1994-2000)] sygn. 176/c/VI - Księga zaślubionych [2001-2002] sygn. 176/c/VII - Księga zaślubionych [2003-2006] sygn. 176/d/I - Księga zmarłych [1987-1992] sygn. 176/d/II - Księga zmarłych [1994-2000] sygn. 176/d/III - Księga zmarłych [2001-2002] sygn. 176/d/IV - Księga zmarłych [2003-2006] sygn. 177 - Księgi parafii pw. św. Józefa Oblubieńca NMP w Sękowej sygn. 177/a - Księga inwentarzowa sygn. 177/b - Księga ochrzczonych [1992-2006] sygn. 177/c - Księga zaślubionych [1992-2006] sygn. 177/d - Księga zmarłych [1992-2006] sygn. 178 - Księgi parafii pw. św. Józefa w Siedliskach k. Rzeszowa sygn. 178/a - Księga inwentarzowa [stan z 2007roku] sygn. 178/b/I - Księga ochrzczonych [1977-1991 (księga),] sygn. 178/b/II - Księga ochrzczonych [1982-2002 (ksero), 2003-2006] sygn. 178/c - Księga zaślubionych [1982-2002 (ksero), 2003-2006] sygn. 178/d - Księga zmarłych [1982-2002 (ksero), 2003-2006] sygn. 179 - Księgi parafii pw. św. Stanisława BM w Sieklówce sygn. 179/a - Księga inwentarzowa [ksero] sygn. 179/b - Księga ochrzczonych [1990-2002 (ksero), 2003-2006] sygn. 179/c - Księga zaślubionych [1993-2002 (ksero), 2003-2006] sygn. 179/d - Księga zmarłych [1990-2002 (ksero), 2003-2006] sygn. 180 - Księgi parafii pw. św. Klemensa Papieża w Skalniku sygn. 180/a - Księga inwentarzowa [ksero] sygn. 180/b - Księga ochrzczonych [1976-1996, 1996-2006] sygn. 180/c - Księga zaślubionych [1985-1997 (ksero), 1998-2006] sygn. 180/d - Księga zmarłych [1993-2002 (ksero), 2003-2006] sygn. 181 - Księgi parafii pw. św. Józefa i św. św. Piotra i Pawła w Skołyszynie sygn. 181/a - Księga inwentarzowa [ksero] sygn. 181/b/I - Księga ochrzczonych [1984-1993] 
sygn. 181/b/II - Księga ochrzczonych [1994-2003-2006]

sygn. 181/c - Księga zaślubionych [1986-2003-2006]

sygn. 181/d - Księga zmarłych [1986-2003-2006]

sygn. 182 - Księgi parafii pw. św. Katarzyny w Sławęcinie

sygn. 182/a - Księga inwentarzowa [stan z dnia 13 III 2004]

sygn. 182/b - Księga ochrzczonych [1986-2001, 2002 (ksero), 2003-2006]

sygn. 182/c - Księga zaślubionych [1986-2001, 2002 (ksero), 2003-2006]

sygn. 182/d - Księga zmarlych [1986-2001, 2002 (ksero), 2003-2006]

sygn. 183 - Księgi parafii pw. św. Michała Archanioła w Smerekowcu

sygn. 183/a - Księga inwentarzowa [ksero, stan z 1995roku]

sygn. 183/b - Księga ochrzczonych [1990-2006]

sygn. 183/c - Księga zaślubionych [1990-2006]

sygn. 183/d - Księga zmarłych [1990-2006]

sygn. 184 - Księgi parafii pw. św. Jana Chrzciciela w Sokołowie Małopolskim

sygn. 184/a/I - Księga inwentarzowa [kościół parafialny]

sygn. 184/a/II - Księga inwentarzowa [kościół pw. Św. Ducha]

sygn. 184/b - Księga ochrzczonych [1992-2006]

sygn. 184/c - Księga zaślubionych [1992-2006]

sygn. 184/d - Księga zmarłych [1992-2006]

sygn. 185 - Księgi parafii pw. św. Katarzyny w Starym Żmigrodzie

sygn. 185/a - Księga inwentarzowa [stan z 2003roku]

sygn. 185/b - Księga ochrzczonych [1990-2002 (ksero), 2003-2006]

sygn. 185/c - Księga zaślubionych [1990-2002 (ksero), 2003-2006]

sygn. 185/d - Księga zmarłych [1990-2002 (ksero), 2003-2006]

sygn. 186 - Księgi parafii pw. św. Maksymiliana Kolbego w Stępinie

sygn. 186/a - Księga inwentarzowa [2005]

sygn. 186/b - Księga ochrzczonych [1983-2002; 2003-2006]

sygn. 186/c - Księga zaślubionych [1983-2002; 2003-2006]

sygn. 186/d - Księga zmarłych [1986-2002; 2003-2006]

sygn. 187 - Księgi parafii pw. Niepokalanego Serca NMP w Stobiernej

sygn. 187/a- Księga inwentarzowa [brak]

sygn. 187/b - Księga ochrzczonych [2003-2004]

sygn. 187/c - Księga zaślubionych [2003-2004]

sygn. 187/d - Księga zmarłych [2003-2004]

sygn. 188 - Księgi parafii pw. Matki Bożej Nieustającej Pomocy w Straszydlu

sygn. 188/a - Księga inwentarzowa [ksero. stan z roku 2002/3]

sygn. 188/b/I - Księga ochrzczonych [1982-1987]

sygn. 188/b/II - Księga ochrzczonych [1987-2002; 2003-2006]

sygn. 188/c - Księga zaślubionych [1980-2002; 2003-2006]

sygn. 188/d/I - Księga zmarłych [1975-1991]

sygn. 188/d/II - Księga zmarlych [1992-2002; 2003-2006]

sygn. 189 - Księgi parafii pw. Matki Bożej Królowej Polski w Strażowie

sygn. 189/a - Ksiega inwentarzowa [rok 2000]

sygn. 189/b - Księga ochrzczonych [1986-1994, 1995-2006]

sygn. 189/c - Księga zaślubionych [1986-1991, 1992-2006] 
sygn. 189/d - Księga zmarłych [1992-2002; 2003-2006]

sygn. 190 - Księgi parafii pw. Niepokalanego Poczęcia NMP i Bożego Ciała w Strzyżowie

sygn. 190/a - Księga inwentarzowa [2002, 2003]

sygn. 190/b - Księga ochrzczonych [1992-2006]

sygn. 190/c - Księga zaślubionych [1992-2006]

sygn. 190/d - Księga zmarłych [1992-2006]

sygn. 191 - Księgi parafii pw. św. Józefa Sebastiana Pelczara w Strzyżowie

sygn. 191/a - Księga inwentarzowa [stan z 2006roku]

sygn. 191/b - Księga ochrzczonych [2003-2006]

sygn. 191/c - Księga zaślubionych [2003-2006]

sygn. 191/d - Księga zmarłych [2003-2006]

sygn. 192 - Księgi parafii pw. Św. Michała Archanioła w Stykowie

sygn. 192/a - Księga inwentarzowa [stan z 2003roku]

sygn. 192/b - Księga ochrzczonych [2004-2006]

sygn. 192/c - Księga zaślubionych [2004-2006]

sygn. 192/d - Księga zmarłych [2004-2006]

sygn. 193 - Księgi parafii pw. św. Marcina w Szebniach

sygn. 193/a - Księga inwentarzowa [brak]

sygn. 193/b - Księga ochrzczonych [1980-2003-2006]

sygn. 193/c - Księga zaślubionych [1980-2003-2006]

sygn. 193/d - Księga zmarłych [1980-2001, 2002-2006]

sygn. 194 - Księgi parafii pw. Matki Bożej Ostrobramskiej w Szufnarowej

sygn. 194/a - Księga inwentarzowa [2003]

sygn. 194/b - Księga ochrzczonych (I - [1971-1982]; II - [1983 - 1993]; III $-[1994-2006])$

sygn. 194/c - Księga zaślubionych [1970-2003-2006]

sygn. 194/d - Księga zmarłych (I - [1971-1994]; II - [1994-2006])

sygn. 195 - Księgi parafii pw. św. Anny w Święcanach

sygn. 195/a - Księga inwentarzowa [ksero, stan z 1971roku]

sygn. 195/b - Księga ochrzczonych [1981-1989, 1989-1998, 1999-2006]

sygn. 195/c - Księga zaślubionych [1990-2006]

sygn. 195/d - Księga zmarłych [1981-2006]

sygn. 196 - Księgi parafii pw. Wniebowzięcia NMP w Świlczy

sygn. 196/a - Księga inwentarzowa [2003]

sygn. 196/b - Księga ochrzczonych [1990-2003 (ksero), 2003-2006]

sygn. 196/c - Księga zaślubionych [1990-2003 (ksero), 2003-2006]

sygn. 196/d - Księga zmarłych [1990-2003, 2003-2006]

sygn. 197 - Księgi parafii pw. Narodzenia NMP w Tarnowcu

sygn. 197/a - Księga inwentarzowa [ksero]

sygn. 197/b/I - Księga ochrzczonych [1974-1988]

sygn. 197/b/II - Księga ochrzczonych [1989-2002]

sygn. 197/b/III - Księga ochrzczonych [2003-2006]

sygn. 197/c/I - Księga zaślubionych [1973-2002]

sygn. 197/c/II - Księga zaślubionych [2003-2006] 
sygn. 197/d - Księga zmarłych [1974-2001, 2002-2006]

sygn. 198 - Księgi parafii pw. Matki Bożej Fatimskiej w Terliczce

sygn. 198/a - Księga inwentarzowa [ksero]

sygn. 198/b - Księga ochrzczonych [1993-2002 (ksero), 2003-2006]

sygn. 198/c - Księga zaślubionych [1993-2002 (ksero), 2003-2006]

sygn. 198/d - Księga zmarłych [1993-2002 (ksero), 2003-2006]

sygn. 199 - Księgi parafii pw. św. Wawrzyńca i Matki Bożej Niepokalanie Poczę-

tej $\mathrm{w}$ Trzcianie

sygn. 199/a - Księga inwentarzowa [(ksero]

sygn. 199/b/I - Księga ochrzczonych [1987-2000]

sygn. 199/b/II - Księga ochrzczonych [2001-2002]

sygn. 199/b/III - Księga ochrzczonych [2003-2006]

sygn. 199/c/I - Księga zaślubionych [1990-2002]

sygn. 199/c/II - Księga zaślubionych [2003-2006]

sygn. 199/d/I - Księga zmarłych [1992-2002]

sygn. 199/d/II - Księga zmarłych [2003-2006]

sygn. 199/e - Prośby o dopuszczenie do bierzmowania [2004]

sygn. 200 - Księgi parafii pw. Przemienienia Pańskiego i św. Doroty w Trzcinicy

sygn. 200/a - Księga inwentarzowa

sygn. 200/b - Księga ochrzczonych [1992-2002, 2003-2006]

sygn. 200/c - Księga zaślubionych [1992-2002, 2003-2006]

sygn. 200/d - Księga zmarłych [1992-2002, 2003-2006]

sygn. 201 - Księgi parafii pw. Opatrzności Bożej w Trzebosi

sygn. 201/a - Księga inwentarzowa [ksero]

sygn. 201/b - Księga ochrzczonych [1992-2003 (ksero), 2004-2006]

sygn. 201/c - Księga zaślubionych [1992-2003 (ksero), 2004-2006]

sygn. 201/d - Księga zmarłych [1992-2003 (ksero), 2004-2006]

sygn. 202 - Księgi parafii pw. św. Wojciecha i Niepokalanego Poczęcia NMP

w Trzebownisku

sygn. 202/a - Księga inwentarzowa [stan z 27 II 2003roku (ksero)]

sygn. 202/b - Księga ochrzczonych [2001-2002 (ksero), 2003-2006]

sygn. 202/c - Księga zaślubionych [2001-2002 (ksero), 2005]

sygn. 202/d - Księga zmarłych [2001-2002 (ksero)]

sygn. 203 - Księgi parafii pw. Matki Bożej Częstochowskiej w Trzebusce

sygn. 203/a - Księga inwentarzowa [stan z 2003roku]

sygn. 203/b/I - Księga ochrzczonych [1988-1997]

sygn. 203/b/II - Księga ochrzczonych [1997-2001]

sygn. 203/b/III - Księga ochrzczonych [2002]

sygn. 203/b/IV - Księga ochrzczonych [1988-1993 (ksero), 2003-2006]

sygn. 203/c/I - Księga zaślubionych [1988-2001]

sygn. 203/c/II - Księga zaślubionych [1988-1992 (ksero), 2002-2006]

sygn. 203/d/I - Księga zmarłych [1988-2001]

sygn. 203/d/II - Księga zmarłych [2001-2002]

sygn. 203/d/III - Księga zmarłych [1988-1993 (ksero), 2003-2006]

sygn. 204 - Księgi parafii pw. św. Anny w Trzęsówce 
sygn. 204/a - Księga inwentarzowa [ksero]

sygn. 204/b/I - Księga ochrzczonych [Trzęsówka (1975-1989, 1990-2002), Ostrowy Baranowskie (1975-2002), ksero]

sygn. 204/b/II - Księga ochrzczonych [Jagodnik - 1975-2002, Siedlanka - 1975-

1983, Kosowy - 1974-1984]

sygn. 204/b/III - Księga ochrzczonych [2003-2006]

sygn. 204/c/I - Księga zaślubionych [ksero, Ostrowy Baranowskie - 1975-2002, Jagodnik - 1975-2002, Kosowy - 1975-1982, Siedlanka 1975-1982, Trzęsówka 1975-2002]

sygn. 204/c/II - Księga zaślubionych [2003-2006]

sygn. 204/d/I - Księga zmarłych [Ostrowy Baranowskie (1975-2002), Jagodnik (1975-2002), Kosowy (1975-1982), Siedlanka (1975-1981), Trzęsówka $(1975-2002)]$

sygn. 204/d/II - Księga zmarłych [2003-2006]

sygn. 205 - Księgi parafii pw. Świętej Trójcy w Tyczynie

sygn. 205/a - Księga inwentarzowa [brak]

sygn. 205/b - Księga ochrzczonych [1992-2002, 2003-2006]

sygn. 205/c - Księga zaślubionych [1992-2001, 2003-2006]

sygn. 205/d - Księga zmarłych [1992-2003-2006]

sygn. 206 - Księgi parafii pw. św. Jana Kantego w Ustrobnej

sygn. 206/a - Księga inwentarzowa [uzupełnienie, stan z 2004roku]

sygn. 206/b - Księga ochrzczonych [1970-1987, 1987-2003-2006]

sygn. 206/c - Księga zaślubionych [1970-2003-2006]

sygn. 206/d - Księga zmarłych (I - [1972-1996]; II -[1997-2003-2006])

sygn. 207 - Księgi parafii pw. św. Wawrzyńca w Warzycach

sygn. 207/a - Księga inwentarzowa [brak]

sygn. 207/b - Księga ochrzczonych [1977-1988, 1988-1996, 1997-2003]

sygn. 207/c - Księga zaślubionych [1979-1996, 1996-2002 (ksero),]

sygn. 207/d - Księga zmarłych [1980-2000, 1994-2002 (ksero),]

sygn. 208 - Księgi parafii pw. św. Maksymiliana Kolbego w Weryni

sygn. 208/a - Księga inwentarzowa [stan z 2006]

sygn. 208/b - Księga ochrzczonych [1992-2008]

sygn. 208/c - Księga zaślubionych [1992-2008]

sygn. 208/d - Księga zmarłych [1992-2008]

sygn. 209 - Księgi parafii pw. Matki Bożej Królowej Polski w Widełce

sygn. 209/a - Księga inwentarzowa [ksero]

sygn. 209/b/I - Księga ochrzczonych [1984-1994]

sygn. 209/b/II - Księga ochrzczonych [1995-2007]

sygn. 209/c - Księga zaślubionych [1983-2006]

sygn. 209/c/II - Księga zaślubionych [2007-]

sygn. 209/d - Księga zmarłych [1983-2006]

sygn. 209/d/II - Księga zmarłych [2007-]

sygn. 210 - Księgi parafii pw. Wniebowzięcia NMP w Wielopolu Skrzyńskim

sygn. 210/a - Księga inwentarzowa

sygn. 210/b/I - Księga ochrzczonych [1960-1984] 
sygn. 210/b/II - Księga ochrzczonych [1985-1996]

sygn. 210/b/III - Księga ochrzczonych [1997-2002, 2003-2006]

sygn. 210/c/I - Księga zaślubionych [1960-2002]

sygn. 210/c/II - Księga zaślubionych [2003-2006]

sygn. 210/d/I - Księga zmarłych [1960-2002]

sygn. 210/d/II - Księga zmarlych [2003 -2006]

sygn. 211 - Księgi parafii pw. NMP Królowej Świata w Wiśniowej

sygn. 211/a - Księga inwentarzowa

sygn. 211/b/I - Księga ochrzczonych [1971-1981]

sygn. 211/b/II - Księga ochrzczonych [1982-1994]

sygn. 211/b/III - Księga ochrzczonych [1994-2002, 2003-2006]

sygn. 211/c - Księga zaślubionych [1971-2002, 2003-2006]

sygn. 211/d - Księga zmarłych [1971-2002, 2003-2006]

sygn. 212 - Księgi parafii pw. Świętej Trójcy i Podwyższenia Krzyża Świętego

w Woli Rafałowskiej

sygn. 212/a - Księga inwentarzowa [ksero]

sygn. 212/b - Księga ochrzczonych [1971-1985, 1986-2002, 2003-2006]

sygn. 212/c - Księga zaślubionych [1954-2002, 2003-2006]

sygn. 212/d - Księga zmarłych [1950-2002, 2003-2006]

sygn. 213 - Księgi parafii pw. Matki Bożej Królowej Polski w Woli Zgłobieńskiej

sygn. 213/a - Księga inwentarzowa [stan z 2004roku]

sygn. 213/b - Księga ochrzczonych [1983-2003-2006]

sygn. 213/c - Księga zaślubionych [1983-2003-2006]

sygn. 213/d - Księga zmarłych [1983-2003-2006]

sygn. 214 - Księgi parafii pw. św. Bartłomieja Ap. w Wójtowej

sygn. 214/a - Księga inwentarzowa

sygn. 214/b - Księga ochrzczonych [1990-2002 (ksero), 2003-2006]

sygn. 214/c - Księga zaślubionych [1990-2002 (ksero), 2003-2006]

sygn. 214/d - Księga zmarłych [1990-2002 (ksero), 2003-2006]

sygn. 215 - Księgi parafii pw. Matki Bożej Królowej Polski w Wólce Niedźwiedzkiej

sygn. 215/a - Księga inwentarzowa [brak]

sygn. 215/b - Księga ochrzczonych [2003-2006]

sygn. 215/c - Księga zaślubionych [2003-2006]

sygn. 215/d - Księga zmarłych [2003-2006]

sygn. 216 - Księgi parafii pw. św. Jadwigi Królowej w Wólce Podleśnej

sygn. 216/a - Księga inwentarzowa [stan z 2004roku]

sygn. 216/b/I - Księga ochrzczonych [1983-1997]

sygn. 216/b/II - Księga ochrzczonych [1997-2002]

sygn. 216/b/III - Księga ochrzczonych [2003-2006]

sygn. 216/c/I - Księga zaślubionych [1983-2002]

sygn. 216/c/II - Księga zaślubionych [2003-2006]

sygn. 216/d/I - Księga zmarłych [1984-2002]

sygn. 216/d/II - Księga zmarłych [2003-2006]

sygn. 217 - Księgi parafii pw. Matki Bożej Różańcowej w Wysokiej Głogowskiej 
sygn. 217/a - Księga inwentarzowa

sygn. 217/b/I - Księga ochrzczonych [1972-2002]

sygn. 217/b/II - Księga ochrzczonych [2003-2006]

sygn. 217/c/I - Księga zaślubionych [1988-2002]

sygn. 217/c/II - Księga zaślubionych [2003-2006]

sygn. 217/d/I - s. 1-40, 47-74 - Księga zmarłych [1972-1993]; s. 41-46, 75-128

- Księga zaślubionych [1972-1987]

sygn. 217/d/II - Księga zmarłych [1994-2002]

sygn. 217/d/III - Księga zmarłych [2003-2006]

sygn. 218 - Księgi parafii pw. św. Józefa w Wysokiej Strzyżowskiej

sygn. 218/a - Księga inwentarzowa [ksero]

sygn. 218/b/I - Księga ochrzczonych [1980-1985]

sygn. 218/b/II - Księga ochrzczonych [1986-2003]

sygn. 218/b/III - Księga ochrzczonych [2004-2006]

sygn. 218/c/I - Księga zaślubionych [1972-1990]

sygn. 218/c/II - Księga zaślubionych [1991-2002]

sygn. 218/c/III - Księga zaślubionych [2003-2006]

sygn. 218/d/I - Księga zmarłych [ 1972-1984]

sygn. 218/d/II - Księga zmarłych [1985-2002]

sygn. 218/d/III - Księga zmarłych [2003-2006]

sygn. 219 - Księgi parafii pw. Matki Bożej Wspomożenia Wiernych w Wyżnem

sygn. 219/a - Księga inwentarzowa [ksero, stan z 1994]

sygn. 219/b - Księga ochrzczonych [1990-2006]

sygn. 219/c - Księga zaślubionych [1990-2006]

sygn. 219/d - Księga zmarłych [1990-2006]

sygn. 220 - Księgi parafii pw. Wszystkich Świętych w Zabierzowie

sygn. 220/a - Księga inwentarzowa [stan z 2000roku]

sygn. 220/b/I - Księga ochrzczonych [1987-1993]

sygn. 220/b/II - Księga ochrzczonych [1994-1999]

sygn. 220/b/III - Księga ochrzczonych [2000-2002; 2003; 2004-2006; Kielanówka 2004]

sygn. 220/c - Księga zaślubionych [1987-2002; 2003-2006]

sygn. 220/d/I - Księga zmarłych [1984-1996]

sygn. 220/d/II - Księga zmarłych [1997-2002; 2003-2006]

sygn. 221 - Księgi parafii pw. Matki Bożej Królowej Polski w Zaborowie

sygn. 221/a - Księga inwentarzowa [2003]

sygn. 221/b - Księga ochrzczonych [1992-2002; 2003-2006]

sygn. 221/c - Księga zaślubionych [1992-2002; 2003-2006]

sygn. 221/d - Księga zmarłych [1992-2002; 2003-2006]

sygn. 222 - Księgi parafii pw. Matki Bożej Różańcowej w Zabratówce

sygn. 222/a - Księga inwentarzowa

sygn. 222/b - Księga ochrzczonych [1970-2006]

sygn. 222/c - Księga zaślubionych [1972-2006]

sygn. 222/d - Księga zmarłych [1949-2006]

sygn. 223 - Księgi parafii pw. Narodzenia NMP w Zaczerniu 
sygn. 223/a - Księga inwentarzowa [brak]

sygn. 223/b - Księga ochrzczonych [1999-2002 (ksero), 2004-2006]

sygn. 223/c - Księga zaślubionych [2000-2002 (ksero), 2004-2006]

sygn. 223/d - Księga zmarłych [2000-2002 (ksero), 2004-2006]

sygn. 224 - Księgi parafii pw. Świętych Apostołów Piotra i Pawła w Zagorzycach

sygn. 224/a - Księga inwentarzowa [jest]

sygn. 224/b - Księga ochrzczonych [1961-2005]

sygn. 224/c - Księga zaślubionych [1962-2005]

sygn. 224/d - Księga zmarłych [1961-2005]

sygn. 224A - Księgi parafii Niepokalanego Serca NMP w Zagorzycach Dolnych

sygn. 224A/a - Księga inwentarzowa

sygn. 224/b - Księga ochrzczonych

sygn. 224/c - Księga zaślubionych

sygn. 224/d - Księga zmarłych

sygn. 225 - Księgi parafii pw. św. Jana Chrzciciela w Załężu k. Jasła

sygn. 225/a - Księga inwentarzowa

sygn. 225/b - Księga ochrzczonych [1992-2006]

sygn. 225/c - Księga zaślubionych [1992-2006]

sygn. 225/d - Księga zmarłych [1992-2006]

sygn. 226 - Księgi parafii pw. Matki Bożej Nieustającej Pomocy i św. Floriana

w Załężu k. Rzeszowa

sygn. 226/a - Księga inwentarzowa [2003]

sygn. 226/b/ - Księga ochrzczonych [I - 1987-1998; II - 1999-2006]

sygn. 226/c - Księga zaślubionych [1987-2002 (ksero), 2003-2006]

sygn. 226/d - Księga zmarłych [1987-2002 (ksero), 2003-2006]

sygn. 226A - Księgi parafii pw. NMP Matki Kościoła w Zarębkach

sygn. 226A/a - Księga inwentarzowa

sygn. 226A/b - Księga ochrzczonych

sygn. 226A/c - Księga zaślubionych

sygn. 226A/d - Księga zmarłych

sygn. 227 - Księgi parafii pw. Miłosierdzia Bożego w Zawadce

sygn. 227/a - Księga inwentarzowa

sygn. 227/b - Księga ochrzczonych [1998-2002]

sygn. 227/b/II - Księga ochrzczonych [2003-2006]

sygn. 227/c - Księga zaślubionych [1998-2002]

sygn. 227/c/II - Księga zaślubionych [2003-2006]

sygn. 227/d - Księga zmarłych [1998-2002]

sygn. 227/d/II - Księga zmarłych [2003-2006]

sygn. 228 - Księgi parafii pw. św. Andrzeja Ap. w Zgłobniu

sygn. 228/a - Księga inwentarzowa [brak]

sygn. 228/b - Księga ochrzczonych [1992-2007]

sygn. 228/ - Księga zaślubionych [1992-2004 (ksero), 2005-2007]

sygn. 228/d - Księga zmarłych [1992-2004 (ksero), 2005-2007]

sygn. 229 - Księgi parafii pw. św. Maksymiliana Kolbego w Żarnowej

sygn. 229/a - Księga inwentarzowa [brak] 
sygn. 229/b - Księga ochrzczonych [1992-2002 (ksero), 2003-2006]

sygn. 229/c - Księga zaślubionych [1992-2002 (ksero), 2003-2006]

sygn. 229/d - Księga zmarłych [1992-2002 (ksero), 2003-2006]

sygn. 230 - Księgi parafii pw. Przemienienia Pańskiego w Żyznowie

sygn. 230/a - Księga inwentarzowa

sygn. 230/b - Księga ochrzczonych [1992-2006]

sygn. 230/c - Księga zaślubionych [1992-2006]

sygn. 230/d - Księga zmarłych [1992-2006]

\section{Zespół 7: Akta Kapłanów}

sygn. 1 - Akta Caritas Kapłanów

sygn. 2 - Akta Domu Księży Emerytów

sygn. 3 - Tabele służbowe (w układzie alfabetycznym)

sygn. 3-A - Tabele służbowe PT. Księży: [brak]

sygn. 3-B - Tabele służbowe PT. Księży: [brak]

sygn. 3-C - Tabele służbowe PT. Księży: [brak]

sygn. 3-D - Tabele służbowe PT. Księży: [brak]

sygn. 3-E - Tabele służbowe PT. Księży: [brak]

sygn. 3-F - Tabele służbowe PT. Księży: [brak]

sygn. 3-G - Tabele służbowe PT. Księży: [brak]

sygn. 3-H - Tabele służbowe PT. Księży: [brak]

sygn. 3-I - Tabele służbowe PT. Księży: [brak]

sygn. 3-J - Tabele służbowe PT. Księży: [brak]

sygn. 3-K - Tabele służbowe PT. Księży: [brak]

sygn. 3-L - Tabele służbowe PT. Księży: [brak]

sygn. 3-Ł - Tabele służbowe PT. Księży: [brak]

sygn. 3-M - Tabele służbowe PT. Księży: [brak]

sygn. 3-N - Tabele służbowe PT. Księży: [brak]

sygn. 3-O - Tabele służbowe PT. Księży: [brak]

sygn. 3-P - Tabele służbowe PT. Księży: [brak]

sygn. 3-R - Tabele służbowe PT. Księży: [brak]

sygn. 3-S - Tabele służbowe PT. Księży: [brak]

sygn. 3-T - Tabele służbowe PT. Księży: [brak]

sygn. 3-U - Tabele służbowe PT. Księży: [brak]

sygn. 3-W - Tabele służbowe PT. Księży: [brak]

sygn. 3-Z - Tabele służbowe PT. Księży: [brak]

sygn. 3-Ź - Tabele służbowe PT. Księży: [brak]

sygn. 3-Ż - Tabele służbowe PT. Księży: [brak]

sygn. 4 - Teczki personalne Księży (w układzie alfabetycznym)

sygn. 4/A - Teczki personalne PT. Księży: [brak]

sygn. 4/B - Teczki personalne PT. Księży: Bal Walenty ks.,

sygn. 4/C - Teczki personalne PT. Księży: [brak]

sygn. 4/D - Teczki personalne PT. Księży: [brak]

sygn. 4/E - Teczki personalne PT. Księży: [brak] 
sygn. 4/F - Teczki personalne PT. Księży: [brak] sygn. 4/G - Teczki personalne PT. Księży: [brak] sygn. 4/H - Teczki personalne PT. Księży: [brak] sygn. 4/I - Teczki personalne PT. Księży: [brak] sygn. 4/J - Teczki personalne PT. Księży: [brak] sygn. 4/K - Teczki personalne PT. Księży: [brak] sygn. 4/L - Teczki personalne PT. Księży: [brak] sygn. 4/€ - Teczki personalne PT. Księży: [brak] sygn. 4/M - Teczki personalne PT. Księży: Martyński Kazimierz ks., sygn. 4/N - Teczki personalne PT. Księży: [brak] sygn. 4/O - Teczki personalne PT. Księży: [brak] sygn. 4/P - Teczki personalne PT. Księży: Pasterczyk Andrzej ks., Piesowicz Henryk ks.

sygn. 4/R - Teczki personalne PT. Księży: [brak] sygn. 4/S - Teczki personalne PT. Księży: [brak] sygn. 4/T - Teczki personalne PT. Księży: [brak] sygn. 4/U - Teczki personalne PT. Księży: [brak] sygn. 4/W - Teczki personalne PT. Księży: Wacławski Wołek Antoni i Jan - kapłani, Wrodarczyk Ludwik o. OMI, sygn. 4/Z - Teczki personalne PT. Księży: [brak] sygn. 4/Ź - Teczki personalne PT. Księży: [brak] sygn. 4/Ż - Teczki personalne PT. Księży: [brak] sygn. 5 - Powołania kapłańskie i zakonne

Zespół 8: Akta Instytutów Zakonnych Męskich

sygn. 1 - Akta Towarzystwa św. Franciszka Salezego (Salezjanów) w Rzeszowie sygn. 2 - Akta Zakonu Braci Kaznodziejów (Dominikanów) sygn. 3 - Akta Zakonu Braci Mniejszych Bernardynów w Rzeszowie sygn. 4 - Akta Zakonu Braci Mniejszych Kapucynów sygn. 5- Akta Zakonu Braci Mniejszych Konwentualnych sygn. 6 - Akta Zakonu Braci Mniejszych Reformatów sygn. 7 - Akta Zakonu Kleryków Regularnych Ubogich Matki Bożej Szkół Pobożnych (Pijarów) sygn. 8 - Akta Zgromadzenia Księży Misjonarzy Matki Bożej z La Salette (Saletynów)

sygn. 9 - Akta Zgromadzenia Księży Misjonarzy Świętej Rodziny sygn. 10 - Akta Zgromadzenia Najświętszych Serc Jezusa i Maryi

Zespół 9: Akta Instytutów Zakonnych Żeńskich

sygn. 1 - Akta Sióstr Naszej Pani z La Salette (saletynek) - dom: Rzeszów sygn. 2 - Akta Zakonu Najświętszej Maryi Panny z Góry Karmelu (karmelitanek)

- dom: Rzeszów 
sygn. 3 - Akta Zakonu Nawiedzenia Najświętszej Maryi Panny (wizytek) - dom: Jasło

sygn. 4 - Akta Zgromadzenia Córek Matki Bożej Bolesnej (serafitek) - dom: Bieździedza, Niechobrz, Strzyżów

sygn. 5 - Akta Zgromadzenia Panien Ofiarowania Najświętszej Maryi Panny (prezentek) - dom: Rzeszów (parafia pw. Chrystusa Króla, pw. Matki Bożej

Saletyńskiej, parafia pw. Wniebowzięcia NMP - bernardyńska)

sygn. 6 - Akta Zgromadzenia Sióstr Franciszkanek od Cierpiących - dom: Brzostek sygn. 7 - Akta Zgromadzenia Sióstr Franciszkanek od Pokuty i Miłości Chrześcijańskiej - dom: Klęczany

sygn. 8 - Akta Zgromadzenia Sióstr Franciszkanek Rodziny Maryi (marianek) - dom: Budziwój, Krasne, Rzeszów (parafia pw. Matki Bożej Różańcowej, WSD, DKS)

sygn. 9 - Akta Zgromadzenia Sióstr Miłosierdzia św. Wincentego à Paulo (szarytek) - dom: Jasło, Kąty

sygn. 10 - Akta Zgromadzenia Sióstr Najświętszej Rodziny z Nazaretu (nazaretanek) - dom: Kamień, Kołaczyce, Rzeszów (parafia pw. Judy Tadeusza)

sygn. 11 -Akta Zgromadzenia Sióstr Opatrzności Bożej (opatrznościanek)-dom: Łąka

sygn. 12 - Akta Zgromadzenia Sióstr Sług Jezusa - dom: Rzeszów (parafia pw. Chrystusa Króla)

sygn. 13 - Akta Zgromadzenia Sióstr Służebnic Najświętszego Serca Jezusowego (sercanek) - dom: Biecz, Frysztak, Rzeszów (parafia pw. Chrystusa Króla) sygn. 14 - Akta Zgromadzenia Sióstr Służebniczek Bogarodzicy Dziewicy Niepokalanie Poczętej (służebniczek dębickich) - dom: Góra Ropczycka, Ropczyce, Ropczyce - Witkowice, Sędziszów Młp., Szebnie

sygn. 15 - Akta Zgromadzenia Sióstr Służebniczek Najświętszej Maryi Panny

Niepokalanie Poczętej (służebniczek starowiejskich) - dom: Cmolas, Gorlice

(Glinik Mariampolski, parafia pw. św. Jadwigi Królowej), Jasionka, Kolbuszowa, Medynia Głogowska, Nienadówka, Rudna Wielka, Rzeszów (Słocina, Staromieście, parafia pw. św. Michała), Sokołów Młp.

sygn. 16 - Akta Zgromadzenia Sióstr Szkolnych de Notre Dame - dom: Kupno sygn. 17 - Akta Zgromadzenia Sióstr św. Dominika (dominikanek) - dom: Lipinki, Rzeszów, Tyczyn, Zaczernie

sygn. 18 - Akta Zgromadzenia Sióstr św. Feliksa z Kantalicjo (felicjanek) - dom:

Boguchwała, Chmielnik, Gorlice, Rzeszów (Dom Biskupi, Fara, Katedra) sygn. 19 - Akta Zgromadzenia Sióstr św. Michała Archanioła (michalitek) - dom:

Dobrzechów, Głogów Młp., Jasło (Fara, parafia OO. Franciszkanów), Wideł-

ka, Wielopole Skrzyńskie, Wysoka Strzyżowska

sygn. 20 - Akta Zgromadzenia Sióstr Franciszkanek Pana Jezusa - dom: Rzeszów

(parafia pw. Św. Krzyża)

Zespół 10: Akta Wyższego Seminarium Duchownego w Rzeszowie 
Zespół 11: Akta Sanktuariów Diecezji Rzeszowskiej

sygn. 1a - Akta sanktuarium Przemienienia Pańskiego w Cmolasie

sygn. 1b - Akta sanktuarium Krzyża Świętego we Frysztaku

sygn. 1c - Akta sanktuarium Pana Jezusa Ubiczowanego w Gorlicach

sygn. 1d - Akta sanktuarium Pana Jezusa Ukrzyżowanego w Kobylance

sygn. 2 a - Akta sanktuarium maryjnego w Binarowej

sygn. $2 \mathrm{~b}$-Akta sanktuarium maryjnego w Chmielniku

sygn. $2 \mathrm{c}$-Akta sanktuarium maryjnego w Czudcu

sygn. $2 \mathrm{~d}$-Akta sanktuarium maryjnego w Dębowcu

sygn. 2 e - Akta sanktuarium maryjnego w Lipinkach

sygn. $2 \mathrm{f}$ - Akta sanktuarium maryjnego w Łączkach Jagiellońskich

sygn. $2 \mathrm{~g}$ - Akta sanktuarium maryjnego w Niechobrzu

sygn. $2 \mathrm{~h}$-Akta sanktuarium maryjnego w Ostrowach Tuszowskich

sygn. $2 \mathrm{i}$ - Akta sanktuarium maryjnego w Ropczycach

sygn. $2 \mathrm{j}$ - Akta sanktuarium maryjnego w Rzeszowie - Bernardyni

sygn. $2 \mathrm{k}$-Akta sanktuarium maryjnego w Rzeszowie - Katedrze

sygn. 21 - Akta sanktuarium maryjnego w Rzeszowie - Saletyni

sygn. $2 \nmid$-Akta sanktuarium maryjnego w Rzeszowie - Zalesiu

sygn. $2 \mathrm{~m}$ - Akta sanktuarium maryjnego w Skalniku

sygn. $2 \mathrm{n}$-Akta sanktuarium maryjnego w Sokołowie Małopolskim

sygn. 2 o-Akta sanktuarium maryjnego w Strzyżowie

sygn. $2 \mathrm{p}-$ Akta sanktuarium maryjnego w Tarnowcu

sygn. 3 a - Akta sanktuarium św. Antoniego w Jaśle

sygn. 3 b - Akta sanktuarium św. Rocha w Słocinie

sygn. $3 \mathrm{~d}$-Akta sanktuarium św. o. Pio w Terliczce

Zespół 12: Akta Instytutu Teologicznego im. Jana Pawła II w Rzeszowie

sygn. 1 - Akta Diecezjalnego Studium Katechetycznego (Kolegium Teologicznego)

sygn. 2 - Akta Instytutu Teologiczno-Pastoralnego im. św. Józefa Sebastiana

Pelczara

sygn. 3 - Akta Diecezjalnego Studium Organistowskiego

sygn. 4 - Akta Diecezjalnego Studium Życia Rodzinnego

sygn. 5 - Akta Podyplomowego Studium Wychowania Prorodzinnego

sygn. 6 - Akta Instytutu Formacji Pastoralno-Liturgicznej

sygn. 7 - Akta Studium Nauki Społecznej Kościoła i Studium Politologii

Zespół 13: Akta Caritas Diecezji Rzeszowskiej

sygn. 1 - Akta Centrali Caritas

sygn. 2 - Akta Rzeszowskiego Towarzystwa Pomocy im św. Brata Alberta

sygn. 3 - Akta Centrum dla Osób Niepełnosprawnych i Warsztatów Terapii Zaję-

ciowej w Rzeszowie

sygn. 4 -Akta Ośrodka Caritas w Myczkowcach 
sygn. 5 - Akta Sklepu Caritas w Rzeszowie

sygn. 6 - Akta Stacji Opieki Caritas

sygn. 7 - Akta Warsztatów Terapii Zajęciowej Caritas w Różance

sygn. 8 - Akta Okręgu Caritas Rzeszów

sygn. 8a - Akta Domu Samotnej Matki i Interwencji Kryzysowej w Rzeszowie

sygn. 8b - Akta Domu Pomocy Społecznej im. św. o. Pio w Chmielniku Rzeszowskim

sygn. 9 - Akta Okręgu Caritas Cmolas

sygn. 10 - Akta Okręgu Caritas Gorlice

sygn. 11 - Akta Okręgu Caritas Jasło

sygn. 12 - Akta Okręgu Caritas Biecz

sygn. 13 - Akta Parafialnych Zespołów Caritas

sygn. 14 - Akta Szkolnych Kół Caritas

sygn. 15 - Akta Caritas Academica

Zespół 14: Akta Duszpasterstw

sygn. 1 - Akta Duszpasterstwa Akademickiego

sygn. 2 - Akta Duszpasterstwa Bankowców

sygn. 3 - Akta Duszpasterstwa Charytatywnego

sygn. 4 - Akta Duszpasterstwa Chorych

sygn. 5 - Akta Duszpasterstwa Ekumenicznego, Sekty

sygn. 6 - Akta Duszpasterstwa Głuchoniemych

sygn. 7 - Akta Duszpasterstwa Harcerzy

sygn. 8 - Akta Duszpasterstwa Kobiet

sygn. 9 - Akta Duszpasterstwa Kolejarzy

sygn. 10 - Akta Duszpasterstwa Kręgów Anonimowych Alkoholików

sygn. 11 - Akta Duszpasterstwa Krwiodawców

sygn. 12 - Akta Duszpasterstwa Liturgicznej Służby Ołtarza

sygn. 13 - Akta Duszpasterstwa Ludzi Pracy

sygn. 14 - Akta Duszpasterstwa Mężczyzn

sygn. 15 - Akta Duszpasterstwa Misyjnego

sygn. 16 - Akta Duszpasterstwa Młodzieży

sygn. 17 - Akta Duszpasterstwa Myśliwych

sygn. 18 - Akta Duszpasterstwa Nauczycieli

sygn. 19 - Akta Duszpasterstwa Neokatechumenatu

sygn. 20 - Akta Duszpasterstwa Niepełnosprawnych

sygn. 21 - Akta Duszpasterstwa Niewidomych

sygn. 22 - Akta Duszpasterstwa Nowych Ruchów Katolickich

sygn. 23 - Akta Duszpasterstwa Ochotniczych Hufców Pracy

sygn. 24 - Akta Duszpasterstwa Organistów i służby kościelnej

sygn. 25 - Akta Duszpasterstwa Pielgrzymkowego

sygn. 26 - Akta Duszpasterstwa Podkarpackiego Związku Piłsudczyków

sygn. 27 - Akta Duszpasterstwa Policjantów 
sygn. 28 - Akta Duszpasterstwa ds. Powołań, Instytutów Życia Konsekrowanego

i Stowarzyszeń Życia Apostolskiego

sygn. 29 - Akta Duszpasterstwa Pracowników Energetyki

sygn. 30 - Akta Duszpasterstwa Pracowników Gospodarki Leśnej, Wodnej i Par-

ków Narodowych

sygn. 31 - Akta Duszpasterstwa Pracowników Nauki

sygn. 32 - Akta Duszpasterstwa Pracowników Portu Lotniczego Rzeszów-Jasion-

ka, Duszpasterstwa Łączności

sygn. 33 - Akta Pracowników Duszpasterstwa Przedsiębiorstwa Obrotu Wyroba-

mi Hutniczymi Centrostal w Rzeszowie

sygn. 34 - Akta Duszpasterstwa Pracowników Wodociągów, Kanalizacji, Gospodarki Komunalnej i Ochrony Środowiska

sygn. 35 - Akta Duszpasterstwa Prawników

sygn. 36 - Akta Duszpasterstwa Przedsiębiorców

sygn. 37 - Akta Duszpasterstwa Rodzin

sygn. 38 - Akta Duszpasterstwa Rolników

sygn. 39 - Akta Duszpasterstwa Rzemieślników

sygn. 40 - Akta Duszpasterstwa Rzeszowskiego Towarzystwa Miłośników Lwo-

wa i Kresów Wschodnich

sygn. 41 - Akta Duszpasterstwa Samorządowców

sygn. 42 - Akta Duszpasterstwa Służby Zdrowia, Pielęgniarek i Położnych

sygn. 43 - Akta Duszpasterstwa Sportowców

sygn. 44 - Akta Duszpasterstwa Straży Pożarnych

sygn. 45 - Akta Duszpasterstwa Sybiraków

sygn. 46 - Akta Duszpasterstwa Środków Społecznego Przekazu

sygn. 47 - Akta Duszpasterstwa Środowisk Twórczych

sygn. 48 - Akta Duszpasterstwa Światowego Związku Żołnierzy Armii Krajowej

i WiN-u

sygn. 49 - Akta Duszpasterstwa Trzeźwościowego

sygn. 50 - Akta Duszpasterstwa Turystów

sygn. 51 - Akta Duszpasterstwa Więziennego

sygn. 52 - Akta Duszpasterstwa Wojskowego

sygn. 53 - Akta Duszpasterstwa Związku Inwalidów Wojennych, Rodzin Katyńskich

sygn. 54 - Akta Duszpasterstwa Ormian

sygn. 55 - Akta Duszpasterstwa Ogrodników

sygn. 56 - Akta Duszpasterstwa Emigrantów

sygn. 57 - Akta Duszpasterstw (inne)

Zespół 15: Akta kapelanii Domów Pomocy Społecznej

sygn. 1 - Akta kapelanii Domu Pomocy Społecznej w Babicy

sygn. 2 - Akta kapelanii Domu Pomocy Społecznej w Chmielniku Rzeszowskim

sygn. 3 - Akta kapelanii Domu Pomocy Społecznej w Gorlicach

sygn. 4 - Akta kapelanii Domu Pomocy Społecznej w Gorlicach-Gliniku 
sygn. 5 - Akta kapelanii Domu Pomocy Społecznej w Kamionce sygn. 6 - Akta kapelanii Domu Pomocy Społecznej w Rzeszowie ul. Sucharskiego

sygn. 7 - Akta kapelanii Domu Pomocy Społecznej w Załężu

sygn. 8 - Akta kapelanii Domu Pomocy Społecznej Caritas w Cmolasie sygn. 9 - Akta kapelanii Domu Pomocy Społecznej Caritas w Sękowej

sygn. 10 - Akta kapelanii Domu Pomocy Społecznej i Domu Kombatanta w Rzeszowie-Słocinie

sygn. 11 - Akta kapelanii Domu Pomocy Społecznej i Sanatorium w Górnie sygn. 12 - Akta kapelanii Domu Pomocy Społecznej Sióstr Opatrzności Bożej w Łące

Zespół 16: Akta kapelanii szpitalnych

sygn. 1 - Akta kapelanii Szpitala Rejonowego w Gorlicach

sygn. 2 - Akta kapelanii Szpitala Rejonowego w Jaśle

sygn. 3 - Akta kapelanii Szpitala Powiatowego w Kolbuszowej

sygn. 4 - Akta kapelanii Szpitala Miejskiego w Rzeszowie

sygn. 5 - Akta kapelanii Szpitala MSW w Rzeszowie

sygn. 6 -Akta kapelanii Wojewódzkiego Szpitala Specjalistycznego (nr 1) w Rzeszowie

sygn. 7 - Akta kapelanii Szpitala Wojewódzkiego nr 2 w Rzeszowie

sygn. 8 - Akta kapelanii Zakładu Opieki Paliatywnej w Rzeszowie

sygn. 9 - Akta kapelanii Szpitala Powiatowego w Sędziszowie Młp.

sygn. 10 - Akta kapelanii Szpitala Powiatowego w Strzyżowie

Zespół 17: Akta Stowarzyszeń Katolickich

sygn. 1 - Akta Akcji Katolickiej Diecezji Rzeszowskiej

sygn. 2 - Akta Fundacji Pomocy Dzieciom i Młodzieży im. Jana Pawła II „Wzrastanie"

sygn. 3 - Akta Fundacji SOS-Obrony Poczętego Życia, Ruchów Obrony Życia Poczętego

sygn. 4 - Akta Katolickiego Stowarzyszenia „Civitas Christiana”

sygn. 5 - Akta Katolickiego Stowarzyszenia Dziennikarzy

sygn. 6 - Akta Katolickiego Stowarzyszenia Inwalidów Wzroku im. Matki Elżbiety Róży Czackiej

sygn. 7 - Akta Katolickiego Stowarzyszenia Kolejarzy Polskich

sygn. 8 -Akta Katolickiego Stowarzyszenia Lekarzy Polskich

sygn. 9 - Akta Katolickiego Stowarzyszenia Młodzieży Diecezji Rzeszowskiej

sygn. 10 - Akta Katolickiego Stowarzyszenia Niepełnosprawnych

sygn. 11 - Akta Katolickiego Stowarzyszenia Pielęgniarek i Położnych

sygn. 12 - Akta Katolickiego Stowarzyszenia „Pokój i Dobro”

sygn. 13 - Akta Katolickiego Stowarzyszenia Wychowawców 
sygn. 14 - Akta Katolickiego Towarzystwa Śpiewaczego - Chór Chłopięco-Męski w Rzeszowie

sygn. 15 - Akta Klubu Inteligencji Katolickiej

sygn. 16 - Akta Polskiego Towarzystwa Nauczycieli

sygn. 17 - Akta Katolickiego Towarzystwa Oświatowego w Jaśle

sygn. 18 - Akta Salezjańskiej Organizacji Sportowej Rzeczypospolitej Polskiej

sygn. 19 - Akta Stowarzyszenia Miłość i Odpowiedzialność

sygn. 20 - Akta Stowarzyszenia Przyjaciół Wyższego Seminarium Duchownego

w Rzeszowie

sygn. 21 - Akta Stowarzyszenia Rodzin Katolickich

sygn. 22 - Akta Stowarzyszenia Rodzin Wielodzietnych

sygn. 23 - Akta Stowarzyszenia Ruch Kultury Chrześcijańskiej „Odrodzenie”

sygn. 24 - Akta Stowarzyszenia Współpracowników Salezjańskich

sygn. 25 - Akta Towarzystwa Przyjaciół Katolickiego Uniwersytetu Lubelskiego sygn. 26 - Akta Towarzystwa „Altum”

sygn. 27 - Akta Katolickiego Stowarzyszenia Sportowców

sygn. 28 - Akta Katolickiego Klubu Sportowego „Alpin”

Zespół 18: Akta Ruchów Katolickich

sygn. 1 - Akta Katolickiego Ruchu Antynarkotycznego „Karan”

sygn. 2 - Akta organizacji Dziewczęca Służba Maryjna

sygn. 3 - Akta Ruchu Domowego Kościoła

sygn. 4 - Akta Ruchu Focolari

sygn. 5 - Akta Ruchu Odnowy w Duchu Świętym

sygn. 6 - Akta Ruchu Neokatechumenalnego

sygn. 7 - Akta Ruchu Apostolstwa Młodzieży

sygn. 8 - Akta Ruchu dla Lepszego Świata (Movimento per il Mondo Migliore)

sygn. 9 - Akta Ruchu Krzewienia Duchowej Adopcji

sygn. 10 - Akta Ruchu Pomocników Maryi Matki Kościoła

sygn. 11 - Akta Ruchu Rodzin Nazaretańskich

sygn. 12 - Akta Ruchu Światło-Życie Diecezji Rzeszowskiej (Oaza)

sygn. 13 - Akta Ruchu Wspólnot „Wiara i Światło”

sygn. 14 - Akta Ruchu ,Effatha”

sygn. 15 - Akta Ruchu Obrony Bezrobotnych

sygn. 16 - Akta Ruchu Czystych Serc

sygn. 17 - Akta Ruchu Społecznego ku Cywilizacji Miłości

sygn. 18 - Akta Szkoły Nowej Ewangelizacji

Zespół 19: Akta katolickich organizacji dewocyjnych

sygn. 19a - organizacje poświęcone Osobom i Tajemnicom Boskim

sygn. 19a/1 - Akta Apostolstwa Modlitwy (Apostolstwa Serca Jezusowego)

sygn. 19a/2 - Akta Bractwa Najświętszego Sakramentu

sygn. 19a/3 - Akta Bractwa Najświętszego Serca Pana Jezusa 
sygn. 19a/4 - Akta Grupy Modlitewnej Miłosierdzia Bożego

sygn. 19a/5 - Akta Koła Czcicieli Najdroższej Krwi Chrystusowej

sygn. 19a/6 - Akta Małych Rycerzy Miłosierdzia Bożego

sygn. 19a/7 - Akta Świeckiej Wspólnoty Najświętszych Serc Jezusa i Maryi

sygn. 19b - organizacje poświęcone Matce Bożej

sygn. 19b/1 - Akta Apostolatu Maryjnego Cudownego Medalika

sygn. 19b/ - Akta Apostolstwa Rodziny Saletyńskiej

sygn. 19b/3 - Akta Arcybractwa Straży Honorowej Niepokalanego Serca NMP

sygn. 19b/4 - Akta Bractwa Szkaplerza Najświętszej Maryi Panny z Góry Karmel

sygn. 19b/5 - Akta Grupy Modlitewnej „Medjugorie”

sygn. 19b/6 - Akta Stowarzyszenia Matki Bożej Bolesnej

sygn. 19b/7 - Akta Stowarzyszenia Matki Bożej Patronki Dobrej Śmierci (Apostolstwo Dobrej Śmierci)

sygn. 19b/8 - Akta Stowarzyszenia Żywego Różańca (Róże Różańcowe)

sygn. 19b/9 - Akta Rycerstwa Niepokalanej

sygn. 19b/10 - Akta Sodalicji Mariańskiej

sygn. 19c - organizacje pod wezwaniem Swiętych

sygn. 19c/1 - Akta Apostolskiego Dzieła Pomocy dla Czyśćca

sygn. 19c/2 - Akta Bractwa św. Huberta

sygn. 19c/3 - Akta Bractwa św. Józefa

sygn. 19c/4 - Akta Franciszkańskiego Zakonu Świeckich

sygn. 19c/5 - Akta Grup Modlitewnych św. o. Pio

sygn. 19/c/6 - Akta Bractwa św. Piotra

Zespół 20: Akta organizacji misyjnych

sygn. 1 - Akta Kół Misyjnych

sygn. 2 - Akta Papieskiego Dzieła Misyjnego Dzieci

sygn. 3 - Akta Papieskiego Dzieła Rozkrzewiania Wiary

Zespół 21: Akta organizacji trzeźwościowych

sygn. 1 - Akta organizacji Anonimowi Alkoholicy

sygn. 2 - Akta organizacji Al-Anon (rodziny AA)

sygn. 3 - Akta organizacji Al-Ateen (dzieci AA)

sygn. 4 - Akta Apostolatu Trzeźwości im. św. Maksymiliana Kolbego

sygn. 5 - Akta Bractwa Trzeźwości

sygn. 6 - Akta Kół Trzeźwościowych

sygn. 7 - Akta Krucjaty Wyzwolenia Człowieka

sygn. 8 - Akta Stowarzyszenia Trzeźwościowego „Wolność i Miłość” Diecezji Rzeszowskiej 
Zespół 22: Pisma Diecezjalne

sygn. 1 - Biuletyn Misyjny Diecezji Rzeszowskiej

sygn. 2 - Biuletyn Synodalny Diecezji Rzeszowskiej

sygn. 3 - Biuletyn Synodu Diecezjalnego

sygn. 4 - Droga Rzeszowska. Dodatek Diecezjalny do Tygodnika Młodzieży Katolickiej

sygn. 5 - Kalendarz Liturgiczny Diecezji Rzeszowskiej

sygn. 6 - Niedziela Południowa

sygn. 7 - Resovia Sacra. Studia Teologiczno-Filozoficzne Diecezji Rzeszowskiej sygn. 8 - Schematyzm Diecezji Rzeszowskiej

sygn. 9 - Znak Łaski. Pismo Wyższego Seminarium Duchownego w Rzeszowie sygn. 10 - Zwiastowanie. Pismo Diecezji Rzeszowskiej

sygn. 11 - Źródło Diecezji Rzeszowskiej

Zespół 23: Akta Katolickiego Radia „Via” w Rzeszowie

sygn. 1 - Rada Programowa Radia „Via”

Zespół 24: Akta Redakcji Katolickiej w oddziale Telewizji

Polskiej w Rzeszowie

Zespół 25: Akta Muzeum Diecezjalnego

Zespół 26: Akta Wydawnictwa Diecezji Rzeszowskiej

Zespół 27a: Dokumentacja Fotograficzna

sygn. 1 - Peregrynacja kopii Obrazy Matki Boskiej Częstochowskiej w Diecezji

Rzeszowskiej (2001-2002) - dekanaty i parafie w układzie alfabetycznym

Zespół 27b: Dokumentacja Filmowa

sygn. 1 - Peregrynacja Obrazu Matki Boskiej Częstochowskiej w parafii pw. bł. Karoliny w Rzeszowie, 27 VII 2002

sygn. 2 - Peregrynacja Obrazu Matki Boskiej Częstochowskiej w parafii pw. św.

Maksymiliana Kolbe w Żarnowej, 6 IV 2002

sygn. 3 - Peregrynacja Obrazu Matki Boskiej Częstochowskiej w parafii pw. św.

Jacka w Rzeszowie, 18 V 2002

sygn. 4 - Peregrynacja Obrazu Matki Boskiej Częstochowskiej w parafii pw. św.

Wawrzyńca i Matki Bożej Niepokalanie Poczętej w Trzcianie, 30 V 2002

sygn. 5 - Peregrynacja Obrazu Matki Boskiej Częstochowskiej w parafii pw.

Opatrzności Bożej w Trzebosi, 27 VI 2002

sygn. 6 - Peregrynacja Obrazu Matki Boskiej Częstochowskiej w parafii pw.

Wniebowzięcia NMP w Rzeszowie (Bernardyni), 22-23 VII 2002 
sygn. 7 - Nawiedzenie kopii figury Matki Bożej Fatimskiej w Strzyżowie, 20-21 XII 1995roku sygn. 8 - Konsekracja kościoła św. Andrzeja Boboli w Gorlicach, 11 X 1998roku sygn. 9 - Uroczystość poświęcenia Krzyża w Sielcu - Podlasku, 17 VI 2001roku sygn. 10 - Uroczystość poświęcenia i oddania do użytku nowego budynku gimnazjum im. Jana Pawła II, Lubień 16 X 2004roku

sygn. 11 - Poświęcenie Krzyża Milenijnego, Wzgórze Ujazd koło Jasła 27 VI $2004 \mathrm{r}$.

sygn. 12 - Ropczycka Pani

sygn. 13 - Konsekracja siostry Iwony Józefiak OCV, Rzeszów 19 VI 2004roku sygn. 14 - Misterium Męki Pańskiej „Synu, oto Matka Twoja”, Babica 24 III 2002. sygn. 15 - Powrót Generała. Generał M. Zaruski w Rzeszowie i Zakopanem. sygn. 16 - Spotkanie opłatkowe w Jazowej, 20 XII 1997roku sygn. 17 - Uroczystość poświęcenia Kalwarii Miłosierdzia Bożego w Kątach, 14 IX 2000

sygn. $18-$ ZChN - Stronnictwo wielkiego celu. 10 lat Zjednoczenia Chrześcijańsko-Narodowego 1989-1999.

sygn. 19 - I Przegląd Twórczości Artystycznej Mieszkańców Domów Pomocy

Społecznej Województwa Podkarpackiego, Rzeszów 9 X 1999roku

sygn. 20 - Orkiestra Wojskowa Rzeszów z wizytą u Ojca Świętego, Watykan 16-

21 III 1998, cz. 2.

sygn. 21 - Otwarcie szkoły w Szufnarowej

sygn. 22 - Dolina Strugu - Dolina Nadziei, VIII 2001

sygn. 23 - Wizyta w Medycznym Studium Zawodowym w Rzeszowie

sygn. 24 - 1. XXIII Rzeszowska Pielgrzymka na Jasną Górę.

- 2. Pielgrzymka do sanktuariów maryjnych oraz śladami historii powstawania Państwa Polskiego.

sygn. 25 - Jasełka 2000 Wola Zgłobieńska

sygn. 26 - 24 Rzeszowska Piesza Pielgrzymka na Jasną Górę, Sierpień 2001roku

Zespół 27c: Dokumentacja na nośnikach CD

Zespół 28: Akta Procesu Beatyfikacyjnego sługi Bożego ks. Władysława Findysza

sygn. 1 - Kopie akt ks. W. Findysza z archiwów kościelnych - z Archiwum Archidiecezjalnego i Archiwum Wyższego Seminarium Duchownego w Przemyślu

sygn. 2 - Kopie akt śledczych p-ko ks. Findysz Władysław z Archiwum Urzędu Ochrony Państwa w Rzeszowie

sygn. 3 - Kopie akt sprawy karnej ks. W. Findysza z Archiwum Sądu Wojewódzkiego w Rzeszowie

sygn. 4 - Kopie akt s. Heleny Findysz z Archiwum Zgromadzenia Sióstr Franciszkanek Rodziny Maryi w Warszawie

sygn. 5 - Kopia Kroniki kościoła i parafii a Żmigrodzie Nowym, t. 2, z Archiwum Parafialnego w Nowym Żmigrodzie 
sygn. 6 - Wspomnienia o ks. W. Findyszu, listy ks. W. Findysza, prośby o wszczęcie procesu

sygn. 7 - Dokumentacja przygotowawcza do procesu

sygn. 8 - Protokoły przesłuchań

sygn. 9 - Tłumaczenia akt procesowych

sygn. 10 - Dziennik podawczy

sygn. 11 - Proces beatyfikacyjny ks. W. Findysza

sygn. 12 - Publikacje o bł. ks. W. Findyszu

sygn. 13 - Uroczystość beatyfikacyjna ks. W. Findysza

Zespół 29: Akta Synodalne

sygn. 1 - Akta Drugiego Synodu Plenarnego

sygn. 2 - Akta Pierwszego Synodu Diecezji Rzeszowskiej (ASDRz I)

sygn. 2/1 - ASDRz I - nominacje, dekrety, zaproszenia, zawiadomienia

sygn. $2 / 2$-ASDRz I - sesja inauguracyjna

sygn. 2/3 - ASDRz I - media, prasa

sygn. 2/4 -ASDRz I - Komisja Główna

sygn. 2/5 - ASDRz I - Komisje

a. Ludu Bożego

b. Nauczycielskiego Zadania Kościoła

c. Uświęcającego Zadania Kościoła

d. Duszpasterstwa

e. Administracyjno-Prawna

sygn. 2/5a - ASDRz I - Komisja ds. Ludu Bożego

1. Zespół ds. Kapłanów

2. Zespół ds. Powołań i Seminarium

3. Zespół ds. Osób Życia Konsekrowanego

4. Zespół ds. Świeckich

sygn.2/5b - ASDRz I - Komisja ds. Nauczycielskiego Zadania Kościoła

1. Zespół ds. Przepowiadania Homiletycznego

2. Zespół ds. Katechizacji

3. Zespół ds. Środków Społecznego Przekazu

4. Zespół ds. Misji

5. Zespół ds. Nauki

6. Zespół ds. Kultury

sygn. 2/5c - ASDRz I - Komisja ds. Uświęcającego Zadania Kościoła

1. Zespół ds. Sakramentów

2. Zespół ds. Uświęcających Czynności Niesakramentalnych

3. Zespół ds. Śpiewu i muzyki kościelnej

sygn. 2/5d - ASDRz I - Komisja ds. Duszpasterstwa

1. Zespół ds. Struktur Duszpasterskich Diecezji

2. Zespół ds. Rodziny

3. Zespół ds. Społeczności Zorganizowanych

4. Zespół ds. Miłosierdzia chrześcijańskiego 
5. Zespół ds. Trzeźwości

6. Zespół ds. Duszpasterstwa ogólnego i specjalistycznego

sygn. 2/5e - ASDRz I - Komisja ds. Administracyjno-Prawnych

1. Zespół ds. Sądu Biskupiego

2. Zespół ds. Socjalno-Ekonomicznych

3. Zespół ds. Majątku Trwałego

4. Zespół ds.. Administracji Diecezji

sygn. 2/6 - ASDRz I - Dokumentacja ze spotkań dekanalnych

sygn. 2/7 - ASDRz I - Zespoły Synodalne - Statystyka

sygn. 2/8 - ASDRz I - Statuty (projekty)

Zespół 30: Druki ulotne i plakaty

Zespół 31: Czasopisma religijne (parafialne i organizacyjne)

i społeczno-polityczne

sygn. 31- A - Arka. Miesięcznik parafii Przybyszówka

sygn. 31- P - Przemiana. Gazeta Rzeszowskiego Towarzystwa Pomocy im. św.

Brata Alberta - Klubu Albertyńskiego

sygn. 31-A - Agape. Pismo oazowe parafii św. Michała w Rzeszowie

sygn. 31-D - Dobry Pasterz (Jasło - Sobniów)

sygn. 31-G - Gazetka Parafialna (pismo parafii w Czarnej Sędziszowskiej).

sygn. 31-G - Głos Św. Bartłomieja. Miesięcznik parafii Dębowiec

sygn. 31-G - Głos św. Onufrego [miesięcznik parafii Łąka]

sygn. 31-H - Hetman Królowej Polski. Parafia wojskowa Matki Bożej Królowej

Polski w Rzeszowie. [grudzień 1993 - wydanie specjalne].

sygn. 31-J - Józef [miesięcznik parafii św. Józefa na Staromieściu - ukazuje się od 1998roku]

sygn. 31-M - Mały Michael - pismo dla dzieci parafii św. Michała w Rzeszowie sygn. 31-M - Michael. Gazetka Parafii Św. Michała w Rzeszowie

sygn. 31-N - Nasz Znak. Pismo Kola Stowarzyszenia Rodzina Katolickich Diece-

zji Rzeszowskiej przy parafii Podwyższenia Krzyża Świętego w Rzeszowie sygn. 31-N - Nie jesteś sam [gazetka KSM parafii Grodzisko Strzyż.]

sygn. 31-O - Oczekiwanie [Echo religijne Zaczernia - miesięcznik parafialnogminny]

sygn. 31-P - Parafia Katedralna. Pismo parafii pod wezwaniem Najświętszego

Serca Jezusowego w Rzeszowie

sygn. 31-P - Parafianin. Miesięcznik Parafii pw. Św. Jana Chrzciciela w Bratkowicach

sygn. 31-P - Posłanie. Biuletyn parafii św. Józefa w Skołyszynie

sygn. 31-P - Promyczek z Jazowej [miesięcznik - parafia Wiśniowa]

sygn. 31-P - Prosto z Fary. Dwumiesięcznik parafii Wszystkich Świętych w Kolbuszowej

sygn. 31-S - Saletyn. Dwumiesięcznik Parafii MB. Saletyńskiej w Rzeszowie sygn. 31-S - Siew. Parafialny Miesięcznik Katolicki (Nockowa) 
sygn. 31-T - Tak. Teraz Akcja Katolicka. Pismo Akcji Katolickiej Diecezji Rzeszowskiej

sygn. 31-W - W blasku Przemienienia. Pismo sanktuarium Przemienienia Pańskiego w Cmolasie

sygn. 31-W - Wieczernik. [kwartalnik - parafia Babica]

sygn. 31-W - Wolność i Miłość. Czasopismo Stowarzyszenia Trzeźwościowego

„Wolność i Miłość” Diecezji Rzeszowskiej

sygn. 31-W - Wspólnota Serca. Pismo parafii pw. św. Brata Alberta w Kolbuszowej

sygn. 31-W - Wspólnota. Miesięcznik Ropczyckich Parafii

sygn. 31-W - Watra. Pismo Katolickiego Stowarzyszenia Młodzieży Diecezji

Rzeszowskiej

sygn. 31-Z - Z Życia Rodzin Katolickich. Pismo Stowarzyszenia Rodzin Katolickich Diecezji Rzeszowskiej

sygn. 31-Z - Zaufaj Jezusowi [dwumiesięcznik parafii Rzeszów-Biała]

sygn. 31-P - Podkarpacki Biuletyn Informacyjny Ligi Polskich Rodzin

sygn. 31-K - Kącik. Gazetka szkolna Zespołu Szkół Społecznych nr 1 w Rzeszowie sygn. 31-O - Obserwator. Tygodnik Rolników

sygn. 31-C - Cebulka. Pismo Regionalne. Wydawca. Stowarzyszenie Przyjaciół

Wsi Warzyce

Zespół 32: Akta Poligrafii Wyższego Seminarium Duchownego w Rzeszowie

Zespół 33: Opracowania niedrukowane

sygn. A/1 - [brak]

sygn. B/1 - Bereta M., Historia parafii Klęczany (1987-2000), Kraków 2002, mps. sygn. G/1 - Gawęda o Wilkowyi i zakonie pijarów w Rzeszowie, oprac. I. Mikuła, mps.

sygn. G/ - Grzebień L., Parafia w Strzyżowie i kult Matki Bożej Niepokalanej,

Kraków 1996, mps.

sygn. I/1 - Idzik M., Historia parafii Nockowa (1945-2000), Kraków 2002, mps.

sygn. M/1 - Malak F., Dzieje parafii Tyczyn, Rzeszów 1970, mps.

sygn. M/2 - Malak F., Z dziejów wsi Hermanowa, 1985, mps.

sygn. M/3 - Micek J., Dzieje duszpasterstwa w Gliniku Mariampolskim w latach 1907 - 1997, mps.

sygn. M/4 - Mucha A., Z Chrystusem na gorlicką Golgotę, mps.

sygn. P/1 - Puzio J., Powołanie i organizacja Wyższego Seminarium Duchownego w Rzeszowie. Aspekt historyczno - prawny, Lublin 2004, mps.

sygn. P/2 - Pazdan D., Historia parafii Bystrzyca (1930-2000), Kraków 2002, mps.

sygn. P/3 - Pociecha E., Historia parafii pw. św. Anny w Ropczycach - Chechłach w latach 1978-2000, Kraków 2002, mps.

sygn. S/1 - Szypuła F., Staromiejskie krzyże - kapliczki - figury, Rzeszów 1999, mps. 
sygn. S/2 - Sądel J., Kościelna władza wykonawcza jako płaszczyzna funkcjonowania wikariusza generalnego, Kraków 1999, mps.

sygn. Z/1 - Zygo W., Parafia pw. św. Maksymiliana Marii Kolbe w Weryni w latach 1978-2000, Rzeszów 2006, mps.

Zespół 34: Akta niekościelnych instytucji i jednostek administracyjnych, samorządowych i publicznych

sygn. 1 - Województwo Podkarpackie

sygn. 2 - Miasto Rzeszów

sygn. 3 - Krajowa Rada Radiofonii i Telewizji

sygn. 4 - Uniwersytet Rzeszowski

sygn. 5 - Polski Związek Chórów i Orkiestr

sygn. 6 - Ruch Społeczny ku Cywilizacji Miłości

sygn. 7 - Dolina Strugu

sygn. 8 - NSZZ „Solidarność”

sygn. 9 - Powiat gorlicki

\section{Zespół 35: Pamiątki rodzinne}

sygn. 1 - Pamiątki rodzinne przekazane przez Teresę Nowak (zam. Rzeszów ul. Grunwaldzka 5 m. 9) - przekazano 3 września 2007roku

\section{Pomocne archiwa kościelne}

Obecne tereny diecezji rzeszowskiej wchodziły w przeszłości w skład metropolii lwowskiej i krakowskiej. Diecezja rzeszowska utworzona została z terenów diecezji przemyskiej i tarnowskiej. Zgodnie z wymogami prawa kościelnego nie wszystkie dokumenty odnoszące się do funkcjonowania parafii włączonych w skład nowej diecezji zostały do niej przekazane ${ }^{36}$. Znajdują się więc $\mathrm{z}$ archiwach instytucji bądź diecezji, do której wcześniej należały. Osobnym tematem są tutaj zasoby archiwów państwowych. Znajdują się one również w archiwach miast, urzędów, do których historycznie dany teren należał.

Do ważniejszych kościelnych archiwów diecezjalnych, w których mogą znajdować się archiwalia dotyczące terenu obecnej diecezji rzeszowskiej należy zaliczyć:

a) Archiwum Kurii Metropolitarnej w Krakowie ${ }^{37}$

ul. Franciszkańska3, 31-004 Kraków

\footnotetext{
${ }^{36}$ M. Dębowska, Archiwa Kościoła Katolickiego w Polsce, Kielce 2002, s.12.

${ }^{37}$ Tamże, s. 47-50.
} 
tel. 0-12 6288132,6288133

e-mail: archiwum@diecezja.krakow.pl

Dyrektor: ks. Andrzej Sapeta

Wicedyrektor: ks. mgr Jarosław Raźny

Współpracownicy: s. Maria Teresa Sawicka SłNSJ, s. mgr Karola Lidia Zaborska SłNSJ

Archiwum czynne od poniedziałku do piątku od 9:00 do 13:00. Nieczynne: w święta kościelne i państwowe, od 23 grudnia do 8 stycznia, w okresie świąt wielkanocnych od Wielkiego Czwartku do wtorku następnego tygodnia włącznie, w lipcu i sierpniu ${ }^{38}$.

b) Archiwum Kapituły Katedralnej w Krakowie ${ }^{39}$

Wawel 3

31-001 Kraków

tel.: 0124229832

www.akkk.com.pl

e-mail: akkk@diecezja.krakow.pl

Dyrektor: ks. prof. dr hab. Jacek Urban

Archiwum czynne od wtorku do piątku w godzinach od 9:00 do 13:00 ${ }^{40}$.

${ }^{38}$ Publikowane informatory o zasobie: Katalog mikrofilmów Ośrodka Archiwów, Bibliotek i Muzeów Kościelnych przy KUL, oprac. B. Kumor, nr 4, ABMK, 31 (1973) s. 283-380; J. Kracik, Najstarsze akta kongregacji dekanalnych $w$ archiwum Kurii Metropolitalnej $w$ Krakowie, ABMK, 29 (1974) s. 172-261; J. Kracik, Zasoby Archiwum Kurii Metropolitalnej w Krakowie, „Analecta Cracoviensia", 9 (1977) s. 471-493; J. Związek, Akta biskupa Karola Skórkowskiego w Archiwum Kurii Metropolitalnej w Krakowie, „Saeculum Christianum”, 1 (1994) nr 2, s. 199-218; Inwentarz dokumentów katyńskich przechowywanych w Archiwum Kurii Metropolitalnej w Krakowie, oprac. S. Jankowski, A. Roliński, Kraków 2002.

${ }^{39}$ Dębowska, Archiwa, s. 45-46.

${ }^{40}$ Publikowane informatory o zasobie: K. Antosiewicz, Katalog inkunabułów Biblioteki Kapituly Metropolitalnej w Krakowie, „Analecta Cracoviensia”, 12 (1980) s. 335-434; Inwentarz Katedry Wawelskiej z roku 1563, ed. A. Bochnak, w: Źródła do dziejów Wawelu, t. 10, red. A. Franaszek, Kraków 1979; Inwentarz skarbca kaplicy Hińczy Rogowskiego w katedrze krakowskiej, wyd. F. Piekosiński, w: Sprawozdanie Komisyi (do badania) Historyi Sztuki w Polsce, t. 4, Kraków 1891, s. 64-79; Rewizje domów Krakowskiej Kapituły Katedralnej, opr. A. Perzanowska, Kraków 2004; I. Polkowski, Katalog rękopisów kapitulnych katedry krakowskiej, Kraków 1884; T. Glemma, Z dziejów Archiwum Kapituly Katedralnej Krakowskiej, „Polonia Sacra”, 4 (1951) z. 4, s. 381-399; I. Polkowski, Sprawozdanie o drugim dziale ksiag Archiwum Kapituly Katedralnej Krakowskiej, Kraków 1885; J. Urban, Archiwum kapitulne pod zarzadem k. Jana Fijałka, AC, 1995, s. 629-636; J. Urban, Katedra na Wawelu 1795-1918, Kraków 2000; J. Urban, Katedra na Wawelu po 1918 roku, Kraków 2008. 


\section{c) Archiwum Arcybiskupa Eugeniusza Baziaka ${ }^{41}$}

ul. Kanonicza 13

31-002 Kraków

tel. $0-124113740$

Archiwistka: s. Danuta Szymańska

Udostępnianie od wtorku do piątku od 9:00 do 13:00 po uprzednim zgłoszeniu telefonicznym ${ }^{42}$.

d) Archiwum Archidiecezjalne obrządku łacińskiego w Przemyślu oraz Archiwum Kapitały Katedralnej w Przemyślu ${ }^{43}$

Archiwum Archidiecezjalne w Przemyślu

Plac Katedralny 4 a

37-700 Przemyśl

tel. 0-16 6786694 w. 38

e-mail: b.archiwum@op.pl

Dyrektor: ks. prał. dr Henryk Borcz

Archiwistka: s. Justyna Kwiecień CSFM

W Archiwum Archidiecezjalnym w Przemyślu zdeponowane są ponadto zbiory

Archiwum Kapitały Katedralnej ${ }^{44}$. Udostępniane są w pracowni Archiwum Archidiecezjalnego.

Czynne codziennie od 9:00 do 13:00 po wcześniejszym uzgodnieniu ${ }^{45}$.

\section{e) Archiwum Kapituły Katedralnej w Sandomierzu}

Archiwum Kapituły Katedralnej w Sandomierzu

${ }^{41}$ Jest to archiwum dawnej archidiecezji lwowskiej, po wojnie przechowywane w częściach w Krakowie, Kalwarii Zebrzydowskiej i Tarnowie, scalone w 1956roku w Lublinie, a w 1977roku umieszczone w Lubaczowie. Od 1995roku siedzibą archiwum jest Kraków. W zbiorach archiwum znajduje się około trzech tysięcy ksiąg metrykalnych ze 163 parafii od XVI do XX wieku. Na miejscu dostępny jest indeks do ksiąg metrykalnych z podaną sygnaturą, rodzajem archiwaliów i datami skrajnymi. Dębowska, Archiwa, s. 51-53.

${ }_{42}$ Publikowane informatory o zasobie: Katalog mikrofilmów Ośrodka Archiwów, Bibliotek i Muzeów Kościelnych przy KUL, oprac. J. Kania, nr 5, ABMK, 51(1985), s. 46-104; M. Leszczyński: Archiwum Archidiecezji w Lubaczowie, ABMK, 53 (1986) s. 57-66.

${ }^{43}$ Dębowska, Archiwa, s. 83-90.

${ }^{44}$ Publikowane informatory o zasobie: Zbiory rękopisów $w$ bibliotekach $i$ muzeach w Polsce, oprac. D. Kamolowa przy współudziale K. Muszyńskiej, Warszawa 1988, s. 217-218; J. Kwolek, Archiwa diecezji przemyskiej obrzędu łacińskiego, „Kronika Diecezji Przemyskiej”, 27 (1927) s. 256-263.

${ }^{45}$ Publikowane informatory o zasobie: J. Kwolek, Archiwa diecezji przemyskiej obrzędu łacińskiego, „Kronika Diecezji Przemyskiej”, 27 (1927) s. 223-276; J. Ataman, Akta wizytacji diecezji przemyskiej do końca XVIII wieku, ABMK, 1 (1960) z. 2, s. 32-44; Katalog mikrofilmów Ośrodka Archiwów, Bibliotek i Muzeów Kościelnych przy KUL, nr 1, oprac. B. Kumor, ABMK, 6 (1963) s. 89-93; nr 2, ABMK, 13 (1966) s. 227; nr 3, ABMK, 24 (1972) s. 247-268. 
27-600 Sandomierz

ul. Katedralna 1

tel. 0-15 832-25-23

p.o. Dyrektora: ks. Roman Chwałek

Udostępnianie po uprzednim uzgodnieniu ${ }^{46}$.

f) Archiwum Diecezji Tarnowskiej ${ }^{47}$

Archiwum Diecezjalne w Tarnowie

ul. Katedralna 3

33-100 Tarnów

www.archiwum.diecezja.tarnow.pl

e-mail: arch-diec@diecezja.tarnow.pl

tel. 0-14 6223423

0-14 6262123

Dyrektor: ks. mgr Stanisław Tokarski

(tel. 014/6223423, tel. m. 014/6268885 wew.14).

Zastępcy: ks. dr Marek Podgórski

ks. mgr lic. Jacek Słowik

Pracownicy: mgr Małgorzata Krużel-Baka

ks. mgr Józef Tabor (tel. 014-69-25-181, kom. 604388899, e-mail: taborjozef@ pro.onet.pl

Archiwum czynne codziennie od 9:00 do 15:00. Soboty od 9:00 do 12:00. W niedziele i święta nieczynne. Przerwa od 12:00 do 13:0048.

${ }^{46}$ Publikowane informatory o zasobie: W. Wójcik, Archiwum i Biblioteka Kapituty w Sandomierzu, ABMK, 7 (1963) s. 5-41; W. Wójcik, Rękopisy Biblioteki Kapitulnej w Sandomierzu, ABMK, 36 (1978) s. 79-103; Zbiory rękopisów, s. 224; Pergaminy Archiwum Kapituły Katedralnej Sandomierskiej, oprac. F. Kiryk, Sandomierz 2002.

${ }^{47}$ Dębowska, Archiwa, s. 98-100; NDAP, Archiwa w Polsce, s. 90.

${ }^{48}$ Publikowane materiały o zasobie: Archiwum Diecezjalne $w$ Tarnowie, oprac. ks. B. Kumor, ABMK, 2 (1960) z. 1-2, s. 43-52; Katalog mikrofilmów Ośrodka Archiwów, Bibliotek i Muzeów Kościelnych przy KUL, nr 4, oprac. B. Kumor, ABMK, 31 (1975) s. 314-328. 


\title{
THE DIOCESAN ARCHIVE IN RZESZÓW. ESTABLISHMENT, FONDS AND ACTIVITY
}

\begin{abstract}
Summary
The article focuses on the establishment, fonds and activity of the Diocesan Archive in Rzeszów. The Archive in Rzeszów plays an important role. Its purpose is to protect, collect, organise, permanently store the archival materials and make them available. The Diocese of Rzeszów was established by John Paul II in his bull Totus Tuus Poloniae Populus of 25 March 1992. The Diocesian Archive in Rzeszów is a separate scientific and cultural institution established by the Bishop of Rzeszów, Kazimierz Górny. It is located at the seat of Diocesian Curia in Rzeszów at Castle Street 4. In the years 1992-1999 the Rev. Dr Stanisław Nabywaniec was responsible for organizing the Archive. In 1999 this task was assigned to the Rev. dr Andrzej Motyka, who was also appointed the Diocesan Archive Director. Soon, the statute and the rules of the Archive were formulated, the structure was established and it became the basis for organising the archival materials. The materials have been available since 2003 .

The article presents the role of the historical archive in the diocese, the origins of the Diocese of Rzeszów, the aims and tasks of the Diocesan Archive in Rzeszów. Then, it focuses on the statute, the rules and organization of the Archive. A significant element of the article is the collection of the Diocesan Archive in Rzeszów (the collection structure) which contains 35 fonds. The final part shows the details about church archives, where we can find archival materials relating to the current area of the Diocese of Rzeszów, which was formed from parts of the Diocese of Przemyśl and Tarnów. Previously, this area was the part of the Metropolis of Lvov and Krakow. The paper also provides the list of archives helpful to the researchers of history of the mentioned area: the Archive of the Metropolitan Curia in Krakow, the Archive of the Cathedral Chapter of Krakow, Archbishop Eugeniusz Baziak Archive, the Archdiocesan Archive of Latin Rite in Przemyśl, the Archive of the Cathedral Chapter of Przemyśl, the Archive of Cathedral Chapter of Sandomierz and the Archive of the Diocese of Tarnów. The article contains the current contact details for these institutions, directors, opening hours, and the list of guides and articles about fonds.

The paper is the first comprehensive study of the Diocesan Archive in Rzeszów as it has been not presented in the previous studies of the Archives of the Catholic Church in Poland.
\end{abstract}

Translated by Aneta Kiper 